


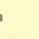



. 



\section{PALAONTOGRAPHICAL SOCIETY.}

INSTITUTED MDCCCXLVII.

L O N D O N :

MDCCCLXXIX-MDCCCLXXXII. 


\section{BRITISH EOCENE FLORA.}

\section{DIRECTIONS TO THE BINDER.}

The Monograph on the British Eocene Flora (Volume I) will be found in the publications of the Palæontographical Society issued for the years 1879,1880 and 1882.

Cancel the Title-pages in the volumes for the years 1879 and 1880 , and substitute the Title-page now provided, and follow the order of binding given in the accompanying table of pages, plates and dates.

ORDER OF BINDING AND DATES OF PUBLICATION OF VOLUME I.

\begin{tabular}{|c|c|c|c|c|}
\hline & PAGES & PLATES & $\begin{array}{l}\text { ISSUE,D IN VOL. } \\
\text { FOR YEAR }\end{array}$ & PUBLISHED \\
\hline Part III & Title-page; Contents & - & 1882 & June, 1882 \\
\hline " I & $1-38$ & $\mathrm{I}-\mathrm{V}$ & 1879 & May, 1879 \\
\hline$" \quad$ II & $39-58$ & $\mathrm{VI}-\mathrm{XI}$ & 1880 & May, 1880 \\
\hline$"$ III & $59-86$ & XII, XIII & 1882 & June, 1882 \\
\hline
\end{tabular}




\section{A MONOGRAPH}

1879

OF THE

\section{B R I TISH}

\section{EOCENE $\mathbb{E} \mathbb{L A}$}

JOHN STARKIE GARDNER, F.G.S., M.G.S. France, \&c., AND CONstantin Baron etTingshausen, Ph.D., PROFESSOR OF BOTANY IN THE UNIVERSITY OF GRATZ, ETC. ETC.
VOL. I 242359
FILICES.

LIONDON :

PRINTED FOR THE PALEONTOGRAPHICAL SOCIETY.

1879-1882. 
PRINTED BY J. E. ADLARD, BARTHOLOMEW CLOSE. 


\section{CONTENTS OF VOLUME I.}

Introduction, BY J. S. Gardner

PAGE

BIBLIOGRAPHY

,

Classification

,

$9-20$

" By Baron Ettingshausen (Figs. 1-10)

. $20-22$

- $22-25$

Descriptions of Species, by Baron Ettingshausen and J. S. Gardner

. $26-57$

Revision of Species, by J. S. Gardner .

- $57-70$

Concluding Remarks

"

. $70-79$

Index of Fossil Species

$81-83$

Index of Living Ferns

84

General Index

$85-86$ 
. 


\section{A MONOGRAPH}

OF THE

\section{BRITISH EOCENE FLORA.}

$\mathrm{BY}$

JOHN STARKIE GARDNER, F.G.S., M.G.S. France, \&c.,

AND

CONstantin Baron etTingshausen, Рн.D.,

PROFESSOR OF BOTANY IN THE UNIVERSITY OF GRATZ, ETC. ETC.

PART I.

FILICES.

Pages 1-38; Plates I-V.

LONDON :

PRINTED FOR THE PALAONTOGRAPHICAL SOCIETY. 
PRINTED BY J. E. ADLARD, BARTHOLOMEW CLOSE. 


\section{A MONOGRAPH}

ON THE

\section{BRITISH EOCENE FLORA.}

\section{INTRODUCTION.}

Aurhovgr for many years no additions have been made to our knowledge of the British Eocene floras, in published works, yet during that period material has been rapidly and steadily accumulating. When, ten years since, my attention was first. directed to the fossil leares which werc then found abundantly at Bournemonth, the extent of the Eocene flora hidden there was not even surmised. It had been stated, in fact, to contain but few types. The fossil leaves of Alum Bay, however, were well known, especially to Mr. Keeping, who had fully ascertained that no very great variety of forms were to be found there. In addition to these, fossil floras were also referred to as having been collected from Studland and the neighbourlood of Corfe. ${ }^{1}$ From the London Basin there were known the Eocene Fruits of Sheppey, and scanty floras from Reading and Dulwich, and from the outlier of the Hampshire Basin at Newhaven. At the present day, however, owing to further collecting, we have available a whole series of extcnsive floras, commencing from that of the Woolwich and Reading beds upwards, embracing the Oldhaven beds, the London Clay, the Lower Bagshot, the Middle Bagshot, and the Upper Eocenes; in fact, from almost every stage of the Eocencs known to occur in this country. This magnificent series of floras of consecutive, and in most cases absolutely defined, age has as yet no parallel in any other country. Its contemplation gives rise to problems, the direction and tendency of which are so unmistakable that, in following the facts as recorded in the succeeding pages, they will be apparent to the student.

I will first call attention to a few examples of the lind of problcms which await solution, and then refer to the value of the determinations of the plaut-remains described in this work. 
Beginning with the Woolwich and Reading Beds, we have a flora, very limited in extent, and consisting of a few, but apparently persistent types, which have a tcmperate facies. It would be interesting if this could be proved to be a fragment of a flora descended from the oldest indigenous dicotyledonous flora of the European or EasternAtlantic area, before the Eoccne temperature had been raised by causes about which I have elsewhere hazarded some speculations. ${ }^{1}$

The next British Eocene flora, sccond in age and supposed to belong to the Oldlaven Beds, has quite another character, as far as we can judge from the present materials. A small collection only has been made; but, by systematic work, results may be looked for not surpassed by those obtained at Bournemouth. These materials seem to indicatc a relation to the Eocene floras of Sézannc. 'The same types, and the same luxuriant preponderance of serratc dicotyledonous leaves, are characteristic of both. It would almost seen that we havc here another really indigenous, but somewhat more sub-tropical, European flora, without the Australian or American types, which later on so very considerably modified it.

In America wc have, though possibly belonging to a far rcmoved age, just such another purely indigenous flora in the so-called Cretaceous Dakota Beds. These floras, which are perfectly distinct from each other, scem to belong to a period antecedent to the connection of Europe and America, although the risc of the afterwards connecting land was probably, I think, even then gradually raising the temperature by shutting off more and more complctely the Arctic currents from the $\Lambda$ tlantic. As at Sézanne, thcre appears to be an abscnce of those Australian forms, especially the Proteacea, which became so abundant at a later Eocene time. Saporta shows that in the so-called Cretaccous and Eocene Europcan floras, wherever European types are present, the Australian element, or, at least, the Proteacea, are almost excluded, and that the rcverse is cqually the case. ${ }^{2}$ But the presence or absence of Australian forms is known in so many localities where they occur, in an apparently arbitrary manner, which cannot be accounted for either by difference of soil or climate, that the thought arises whether it may not be possible that the relative ages of the isolated floras on the Continent have been wrongly inferred. Instcad of appearing and disappearing frequently, did not the members of the Australian flora, like those of the American at a latcr date, come in, in the way newly. introduced species are now seen to do when climatic conditions are favorable? The Australian type of plants had a great and sudden extension until

1 'Nature,' December 12th, 1878, p. 124.

2 With regard to Sézanne, however, it may be urged that there are reasons why leaves of Proteacea should not be found. The flora is evidently that of a shady, moist, and luxuriantly woody valley. The leaves are found in a tufaceous matrix, and must have fallen from overhanging trees and adhered to the sides of a ravine, wet, probably, with the spray of an adjacent waterfall charged with carbonate of lime. Under such conditions travertine rocks are formed rapidly and enclose masses of leaves, as we see at Tivoli, for instance, at the present day. It is, perhaps, unlikely, therefore, that Proteacece, which generally have a dry habitat, even if abounding contemporaneously, would be preserved under such circumstances. 
displaced by the American flora. If so, the floras without Proteacea may, in the absence of other evidence, be looked upon as the more ancient; and we should fix, in some measure, the date of the arrival of that Australian element whose presence in Europe, when discovered and described, eaused so much surprise.

The flora of the London Clay, unlike that of other stages, which are represented by leaves principally, is known from seeds and fruits. I am indisposed at present to speculate upon its affinities, since there is a possibility of obtaining leaves from the Basement Bed. I will merely say that fruits belonging to the same genera, but specifically different, are found in the Middle Bayshot Beds, and that Heer believes the Sheppey fruits and the Alum-Bay leaves belong to the same plants.

The Alum-Bay flora, of Lower Bagslot age, has been so well explored that it is rare, even after long work, to discover any form in it that is new. It abounds with what are generally accepted as Proteaecous leaves, and yet these are mingled with larger leaves of Figs, Laurels, Leguminous plants, and the lobed leaves of Aralias, Maples, \&c., representing a luxuriant flora which did not grow on sterile ground, or in a very dry climate. It is a good example of the Australian type of an Eocene flora, and is most distinct in England from those above and below it.

The newer Bournemouth flora, assigned in this work to the Middle Bagshot stage, appears to be separated from the last by a great interval of time, for the flora scems almost wholly American, and, singular to say, the small Pliocene flora of California, described by Lesquereux, more resembles it generically, though the species are different, than does any other known to me. In it the Proteacea are replaced by the American Myricacee, and it seems to eontain a number of existing American genera not previously recognised among fossils.

If these tentative speculations, founded at present on somewhat superficial knowledge, have any basis of truth, they would show that it was between the Lower and Middle Bagshot periods that North America and Europe were connected by land. The floras of the Upper Eocene merge gradually, without further striking change, into those of the Miocene, whose story has been so often and so ably traced by Heer.

Although all these floras are here spoken of as strikingly disconnected, it must not be supposed they are absolutely so; on the contrary, not a few forms are common to many, and some may be found in all of them.

As the British Eocene floras become better known through the progress of our work thesc speculations may receive eonfirmation or be altogether set aside. I have, however, ventured to put them forward, as they may invest the study with an interest beyond that which the mere description and determination of the Plants alone would possess.

The singularly little attention as yet bestowed upon this subject in England has been doubtless primarily due to the difficulty in satisfactorily determining the fossils. 'These floras, mainly composed of detached dicotyledonous leaves, present such exceptional difficulties that even when very great thought and care have been bestowed upon the 
work, the eorrectness of the results may yet be open to doubt. No author has written upon similar floras without expressing his opinion of the magnitude of these difficulties. Yet, many seem to have forgotten, during the progress of their work, the eaution they insisted on at its commencement. Nothing is more easy than to assign generic and specifie names to leaf-forms; but, with such material, the determinations are so much a matter of opinion that eriticism or contradiction is useless.

The publication, however, of careful drawings of fossil plants is of value; and were the determinations which have been made even more doubtful and provisional in charaeter than they are at present thought to be, it is, nevertheless, a real benefit to science to aceurately figure and deseribe all the obviously different leaves and fruits that have been discovered. Many fossil leaves fade, others crack and peel off from the matrix; dust ean never be completely removed, and necessarily obscures the more delicate venation; indeed, these characters are so easily obliterated that without exceptional care the specimens soon become valncless. Fossil fruits are from other causes equally difficult of preservation. Unfortunately leaves formerly collected in quantity from Corfe, Branksea, Dulwich, and many other places, are no longer to be obtained from these localities; and almost all of the few speeimens still in existence have become so obscure that they give very imperfeet evidence of the nature of these floras. Thus, links in the history of plant-life are lost, perhaps beyond recovery.

As long ago as 1854, Edward Forbes, in his Anniversary Address ${ }^{1}$ to the Geological Society, ealled attention to the necessity of doing something with these floras.

"Were all known fragments of distinct vegetables found in our Tertiaries monographed and named in the manner of those I shall have presently to mention, deseribed and figured in the lately published memoirs by Austrian Botanists, our lists would be eonsiderably increased. They certainly ought to be made the subject of a treatise, and might be advantageously taken up by the Palæontographical Society, which, as yet, has given no separate memoir on British fossil plants."

It is to be greatly regretted that no practical steps have hitherto been taken to accomplish this work, as, since Professor Forbes made this suggestion, instances have come under my own notice in which whole beds of leaves have been either carried away by the sea, or quarried out, or deeply buried under refuse.

It seems likely that thie cautions formerly reiterated by such distinguished men as Hooker, Charles Bmbury, and E. Forbes himself, intended to direct investigation, have had the practical effect of diseouraging British palæontologists from undertaking it, sinee the only writings of importance npon our British Tertiary floras are, with the exception of Bowerbank's description of the fossil fruits of the London Clay, by foreigners. Botanists when consulted have very often, unintentionally no doubt, deterred collectors from taking any further interest in fossil leaf-forms by the emphatic stress they have laid upon the variation to which leaves belonging to the same species of plant are subject, 1 'Quart. Journ. Geol. Soc.,' vol. x, p. lvi. 
and upon plants widely separated in a natural elassification having the same form of leaf. Intending students have been led to think that leaves may not be separated into speeies when they are dissimilar in form, nor united in one when similar. Surely, however, it does not follow that, beeause the task is diffieult, nothing should be attempted. Apart from their determination, if we regard leaves merely as signs, and are indifferent, for instanee, as to whether they belong to Oak, or Beeel, or Elm, or to common aneestors of these, they still possess much interest, sinee frequently on their evidenee alone the date of many a voleanic eruption, ehange of level, or silting up of lakes, has to be fixed. Even in our own eountry, we see that the voleanie outbursts of Mull and the Nortlı of Ireland, and the lake-system at Bovey-'Traecy, have been determined to be of Mioeene age entircly on plant evidenee.

However great the diffieulties may be in determining these fossil plants from the isolated organs whieh alone for the most part we possess, the task is ecrtainly not altogether hopeless. Fortunately we are not wholly dependent upon leaves, but have large series of fruits and seeds as well, and even oeeasional flowers to assist us. Were we, therefore, to find leaves whieh, although scemingly of Oaks, for example, but whieh might be leaves of other and widely separate families, we should hesitate how to class them; but if we find that aeorns had been floated down by the same river whieh brought the leaves, our doubts would be greatly removed. With the inereasing stoek of knowledge sueh results may be hopefully looked for. But even where we have nothing but detached leaves to deal with, mueh may be done. Many plants ean be recognised by the form of the leaves, still more by the venation, and their determination is more eertain when the texture is preserved. The latter is of great importanee; for instanee, the leaves of a species of Nettle and of a Cinnanon have the same venation and form, yet owing to the differenee in their texture they eould, even if fossil, hardly be mistaken. Texture, however, although indieated in the fossil, canıot always be reproduced in the illustrations. Even the leaves of those plants whieh vary mueh ean generally be recognised, if a large series be examined, by their venation, though in outline they may be quite dissinilar. The question is not, however, whether some plants so vary that it is impossible to determine them from their leaves, but it would be important to determine whether the speeies of the living genera to whieh these fossils have been referred are so variable. The liabit of colleeting and attentively examining fossils from deposits of one age, if extended over many years, induees so great a familiarity with their peculiarities of texture and aspeet that they beeome casily reeognisable by minor differences, whieh would eseape even a botanieal specialist who passed then under examination for the first time. Again, eonsiderable advantage is gained by attending to the general assemblage of plants in a fossil flora. As an instanee, we find at Bournemouth a leaf, hitherto supposed to be that of a Castanea, assoeiated abundantly and almost exelusively with Palms and Ferns of tropieal American type. The eorrectness of the determination appears doubtful, sinee we have no precedent for such a grouping, whereas a speeies 
of Godoya even more nearly resembles the Bourncmouth leaf, and its presence might be expected in such company. The large series of the same forms of leaves which I have brought together thus greatly facilitate their determination. 'The limits of variation in many given leaf-forms can be recognised; leaves which would be included as varieties, if found singly, are seen to be persistent in their form. Gradually the work becomes easier; to-day we have but isolated leaves; to-morrow a chance brings to light an assoeiated fruit or flower, a branchlet of lcaves, showing their attachment-some cluc by which conjecture is rendered almost certainty.

In arriving at our decisions respecting the comparativc ages of isolated floras, besides taking into consideration those differences which are likcly to be present when they arc widely separated, eithcr by latitude or longitude, we must makc allowance for local causcs, which influence and even change the character of neighbouring floras at the present day. 'Ihese are so well known that it is ouly necessary to allude to them here. Plant-remains from argillaccous, and arenaceous soils would more or less differ. Limestones, serpentine, and basalts have characteristie plants. Peat and soil impregnated with saline matters nourish plants that are markedly dissimilar. Local differences in climate, such as are caused by the prevalcnee of certain winds, exccss of moisture, proximity to mountain ranges, or to sca-currents of different tempcratures, excrt a powerful influence on vegetation. Difference of altitude, it is well known, makes almost as much change in each foot vertically as in miles horizontally. Some of thesc conditions have no doubt modified the floras to be described.

As plants of the 'l'crtiary period are found in a more and more cxtended arca, wc sec that very frequently leaves, evidently of the same spccics, have been placed by authors in many, and sometimes widely, different genera. As knowledge increases, such differences will in due course becomc corrected. Free interchange of ideas, and, where possible, of spccimens before final publication, would obviate mueh of this burdensome synonomy in the future. It would also be morc dignified and satisfactory were authors of species themselves from time to time to disclaim those which had become synonyms or were founded on insufficient characters or data, instcad of leaving others, not in so good a position, to make the corrections. Eventually it is to be loped that Botanists, who have made especial orders of living plants their study, following the example so wcll sct by Mr. Hiern in his 'Monograph of the Ebenaceæ,' may be tcmpted to devote themselves to a critical examination of the determinations hitherto made, so that the immense importance of Plant Remains, which exceeds in many respects that of Animal Remains, may be eventually conceded to them.

Notwithstanding their importance, no section of Palæontology has bcen more neglected by our fellow-countrymen than the plants of the Tertiary Period. The floras of our oldcr roeks are familiar to us by the works of Lindlcy, Hutton, Williamson, Binney, Carruthers, and otlıers. Phillips has given us a considerable insight into the nature of the British Jurassic flora; but from Oolitic times plant-history is still, so far as this 
country is coneerned, comparatively a blank. It is true that for long ages we have but the seantiest remains to tell us how vegetation progressed in this area, and the subject, until Tertiary times are reached, from its very meagreness, has offered few attractions to its research. Such materials as have been brought to light have been investigated by Carruthers, who has published in a series of papers as mueh as there is known respecting British Cretaceous floras. 'The vast fresh-water deposits of the Wealden, in whieh, from analogy, we should have expected to find series of plant-remains important in the history of evolution, have yiekled littlc else but Ferns, Cycads, and Conifers. The Neoeomian flora appears to have been similar. 'The marine beds of our Cretaceous rocks have from top to bottom yielded only a few isolated remains of Conifers, which had probably been drifted ont to sea. No remains whatever of Dicotyledons have been found in them; and a few rolled pellets of wood, with a palm-like structure, are the only traces of Monocotyledons which they anywhere present.

I liave elsewhere ${ }^{1}$ spoken of the immense gap in the geological record whieh exists in England between our Uppermost Chalk and our Lowest Eocene, completely severing the plant-life of the latter period from all that preceded it. If we turn to other eountries we see that this gap is but partially filled up, for it is still doubtful whether any of the foreign Cretaceous beds containing Dieotyledons were contemporaneons even with our Chalk, our highest member of the series.

From nearly the commencement of our Eocenes, on the contrary, almost every section has been found to contain more or less extensive series of plant-remains, forming a striking contrast, from their abundance and variety, to the remains found in beds preceding them. Although this has long been familiar to English Botanists and Geologists, the only attcmpts to describe English Eocene plants, so far as I know, have, with few exceptions, been on a very limited scale. These are hereafter noticed in detail in their stratigraphical and chronological order.

The nearly unbroken sequence seen in the Eoecne floras extends into the Miocene. There is no great break in passing from one to the other when we compare them over many latitudes, and but little change beyond that brought about by altered temperature or migration. But if Tertiary floras of different ages are met with in one area, great changes on the contrary are seen, and these are mainly due to progressive modifications in climate, and to altered distribution of land. From Middle Eocene to Mioecne the heat imperceptibly diminished. Imperceptibly, too, the tropieal nembers of the flora disappeared; that is to say, they migrated, for most of thcir types, I think, actually survive at the present day, many but very slightly altered. 'T'hen the sub-tropical members decreased, and the temperate forms, never quite absent even in the Middle Eocenes, preponderated. As decreasing temperature drove the tropieal forms soutli, the more northern must have pressed elosely upon them. The Northern Eocene, or the temperate floras of that period, must have pushed, from their home in the far nortll,

1 'The Popular Science Review,' January, 1879, p. 55. 
more and more south as climates chilled, and at last, in the Miocene time, occupied our latitudes. The relative preponderance of these elements, I believe, will assist in determining the age of Tertiary deposits in Europe, more than any minute comparisons of species. 'Thus it is useless to seek in the Arctic Regions for Eocene floras, as we know them in our latitudes, for during the Tertiary period the climatic conditions of the earth did not permit their growth there. Aretic fossil floras of temperate, and therefore Miocene aspect, are in all probability of Eocene age, and what las been recognised in them as a newcr or Miocene facies is due to their laving been first studied in Europe in latitudes which only bccame fitted for them in Miocene times.

When stratigraphical evidence is absent or inconclusive, this unexpected persistence of plant types or species throughout the Tcrtiaries should be remembered, and the degrees of latitude in which they are found should be well considered before conclusions are published respecting their relative age. 


\section{FLOR A}

OF THE

\section{BRITISH EOCENE FORMATIONS.}

\section{Fiora of the Thanet Sand.}

Very little is known of the flora of this earliest Eocene Period of England, and there is some doubt as to the exact age of even the few plant-remains which have been described as belonging to it.

In the second volume of Lindley and Hutton's 'Fossil Flora,' 1833-5, is a figure ${ }^{1}$ of a Conc, described as Zamia macrocepluala, and in the third volume, another called Zamia ovata. ${ }^{2}$ These were supposed to be Cretaceous, but they are now known to be from the Thanet Sands. One is from near Deal, the other from Faversham. Additional material having been discovered, these species were examined and redescribed by Carruthers, in the 'Geological Magazine' for $1866,{ }^{3}$ as Pinites macroceplualus and $P$. ovatus. In 1870 Carruthers read a paper ${ }^{4}$ on Osmundites Dowkeri, a fossil fern-stem from Herne Bay, and in 1872 Thisclton Dyer ${ }^{5}$ described fossil wood from the same locality. Coniferous wood luas also been found, Profcssor Morris informs me, at Richborough in Kent.

\section{Flora of the Woolwich and Reading Beds.}

The earliest notice of the occurrence of plants in these strata is to be found in Webster's paper "On the Strata lying over the Chalk," published in 1814. To Warburton belongs the eredit of having first discovered the remains of fossil leaves at Newhaven. They were mentioned in subsequent papers, and in 1817 Sowerby gave a figure $^{7}$ of the prevailing leaf, which, he conjectured, might be near to Platanus orientalis. Mantell in $1822^{8}$ held the same opinion when he figured the same species with some additional forms.

In 1854, Prestwich figured and Hooker described a number of lcaves and other vegetable remains from Reading and from Counter Hill $;{ }^{9}$ but Hooker declined to hazard

1 Pl. 125, p. 117.

2 Pl. 226, p. 189.

3 Vol. iii, Pls. 20, 21, p. 534.

4. 'Quart. Journ. Geol. Soc.', vol. xxvi, p. 349, pls. 24 and 25; 'Geol. May.,' vol. ix, p. 52.

5 'Geol. Mag.,' vol. ix, p. 52.

6 'Trans. Geol. Soc.,' vol. ii, p. 191.

7 'British Mineralogy,' vol. v, p. 185, pl. 500.

8 Mantell, 'Geol. Sussex,' pl. 8, p. 262.

9 'Quart. Journ. Geol. Soc.,' vol. x, pp. 88 and 163, pl. 4. 
any determinations upon the very insufficient matcrials. Shortly after appeared a note by Hooker ${ }^{1}$ on Carpolithes ovulum from Lewisham, which he supposed was the sporangium of a eryptogamous plant; but this opinion has not been adopted by recent writers, who consider it the sced of a Nymphaceous plant. ${ }^{2}$ Dc-la-Harpe ${ }^{3}$ considered that the Reading leaves might be determined, and in 1856 referred them to various gencra.

In the table of fossils from these beds in the fourth volume of the "Geological Survcy Memoirs,' p. 578, six of these leaves have specific names attached to them.

In 1875 Rupert Jones and Cooper King ${ }^{4}$ noticed fragments of leaf-beds enclosed in strata in a ncwly exposed section at Reading.

A most careful scarch there has resulted up to the present in nothing more than indistinct leaf-remains, principally of Willow form.

Mr. E. S. Dewick informs mc that a bed of leaves was cut through fourteen years since by a railway cxcavation at Mottingham, and has forwarded me the small fragments that were preserved. Other leaf-remains have been found at Charlton.

Very few of the plant-remains from the Woolwich and Rcading Beds are now in a condition to be of value for descriptive purposes; but some, sufficiently well preserved, exist in the British, Jcrmyn Street, and the Gcological Society's Museums, and I possess a series from Dulwich, which wcre formerly in Bowerbank's eollection. In addition to this, in 1878 I obtained from Newhaven a considcrable number of leaves in a beautiful state of preservation. This I esteem the more fortumate, since the leaf-bed is very local and has almost cntirely fallen into the sea, whither it will be followed at no distant date by the rest of the outlier. I shall therefore be able to give an account, though very imperfect, of this Lower-Eocene flora. Little diversity seems its chief fcature, for the greater part of the leaves found by Mantell, Prestwich, and myself, belong to a small number of species. An Aralia-likc leaf has been found at Lewisham. I have not seen any remains of the palms mentioned as coming from the formation, or the cone figured by Prestwich (l. c.), and I fear they may now be disintegrated.

\section{Flora of the Oldhaven Beds.}

Whitaker ${ }^{5}$ mentions plant-remains in these beds from several localities. The most important is at Widmore Kiln, Bromley. Some leaves from that place wcre submitted to Carruthers, who remarked upon them as follows:- "The series of leaves

1 'Quart. Journ. Geol. Soc.,' vol. xi, pl. xvi, p. 562.

2 Schimper, 'Traité de Pal.,' vol. iii, p. 93.

3 'Bull. Soc. Vaudoise,' vol. v, p. 123.

4 'Quart. Journ. Geol. Soc.,' vol. xxxi, p. 451.

5 'Mem. Geol. Surv.,' vol. iv, 1872, pp. 247, 582. 
eontain two well-marked types, whieh have been almost invariably reeognised as belonging to Ficus and Cinnumomum. The earbonised wood is coniferous."

This flora differs materially from that of Alum Bay, and from that of Newhaven, and perhaps more nearly resembles the Bournemouth flora than either of them. It is remarkable that the leaves are usually found adhering to a stem, instead of being detaehed, as is generally the ease elsewhere.

\section{V. Flora of the London Clay.}

The Fossil Fruits of Sheppey have been known for two eenturies at least. They oceur in abundanee in the beds between Slicerness and Warden Point, and are washed out with other organie fragments and eement-stones, and gathered on the beaeh as eopperas. The people engaged in eolleeting the eopperas and eement-stones have for years been aeeustomed to set aside the more defined speeimens; but, unfortunately, the fruits were perishable, and, with few exeeptions, have disintegrated in a very short time.

The earliest notiee of them, aeeording to Whitaker's list of works on the London Basin, ${ }^{1}$ is an anonymons 'Fossilix Sheppeianx Catalogus "' of 1709. The next, 1757, is a paper by Dr. J. Parsons, ${ }^{3}$ in which forty-four varieties of fruits are figured. They were thought to be Figs, Myrobalan, Phaseolus, seeds of an Ameriean Gourd, Coffee-berries, Pods of the Underground Pea, small Melon, Acorn, Plum-stone, Cherrystone, berry of Sapindus, fruit of IIura, Mango, Horse-ehestnut, Coeoa-nut, \&e.

The anthor thonght that if they were antediluvian they would, in some measure, point out the time of year in whieh the deluge began, which eould not have been in May, as supposed by Dr. Woodward, but, from the ripeness of the fruits, in autumn.

In 1777 E. Jaeob, in an Appendix to the 'Plantix Favershamienses,' gives a list of fossil plants from Sheppey, under the lieads of Lignum fossile, Equisetum, Fruetus varii Aristx, and Myeetidx.

In 1811 Parkinson ${ }^{4}$ figured several fruits from Sheppey, but added nothing to Parson's list, exeept the suggestion that Nipadites was probably the fruit of the genus Cocos.

In 1814. Webster ${ }^{5}$ wrote that the eliffs of Sheppey had long been eelebrated, and that from them, with the beds at Faversham and Emsworth, 700 different speeies of fossil fruits were known. In 1828 Brongniart, in his 'Prodrome des Végétaux Fossiles,' deseribes three fruits from Sheppey, to whieh he gives the names of Cocos Partinsonii,

1 'Mem. Geol. Surv.,' vol. iv.

2 'Monthly Miscellany,' vol. iii, p. 163.

3 'Phil. Trans.,' vol. l, p. 396, pl. vi.

4 'Organic Remains, \&c.', vol. i, pls. vi and vii.

5 'T'rans. Geol. Soc.', ser. I, vol, ii, p. 2. The information appears to have been derived from a MS. Catalogue (now in the British Museum), by Francis Crow, of Favershan, dated 1810, illustrated with 831 drawings, supposed by the author to represent about 700 varieties. 
Amomocarpum deprcssum, and Pandanocarpum pyramidatum, and adds that many undetermined species of Carpolithes occur there. In 1832 Lindley and Hutton, in the list of fossil plants, prefixed to the first volume of the 'Fossil Flora," include the species of Brongniart, with some additional forms based on portions of plants, as Palmacites, Flabellaria, Caulinites, Equisetum, and Fucoides.

In 184.0 Bowerbank commenced a ' History of the Fossil Fruits and Seeds of the London Clay,' which was to be completed in five parts. The first part was published, but the second part, although announced as in preparation, never appeared. The illustrations, by J. de C. Sowerby, are particularly well drawn. The descriptions of Nipaditis are remarkably accurate, and the correctness of the author's approximation of them to Nipa lias stood the test of time. Not so, however, the thirteen species into which the author divides them, it being now considered that few of these can be maintained. The author seems throughout to have made too many species. It was supposed that the fruits had been floated from a warmer clime; but Heer, in 1845, pointed out that the leaves found at Alum Bay belonged to sinilar groups. Herne Bay and other localities, in addition to Sheppey, have yielded fossil fruits; and resin, besides fossil wood, has frequently been met with at Highgate. The impressions of leaves have been found in the Basement-Bed of the London Clay at Barnet's End, near Hemel Hempstead.2 I regret that I have not been able to see these plants, which, if well preserved, are of extreme interest.

Ettingshausen has entirely devoted four months' stay in London, made in connection with our work, to a preliminary examination of the Sheppey fruits, and he is already able to announce the presence of the following genera:-Pinus, Callitris, Salisburia; Musa, Sabal, Elais, Iriartea, Livistona, Oenocarpus; Quercus, Liquidambar, Nyssa, Diospyros, Symplocos, Magnolia, Juglans, Eucalyptus, Amygdalus, Bautinia. He further recognises three genera of palms, which he is unable yet to determine, and several new and interesting fruits belonging to Apocynaceæ, Cinchonaceæ, Cucurbitaceæ, \&c.

\section{Flora of the Bagshot Formation.}

The plants of these beds form, when united, by far the most extensive and varied fossil flora, of approximately one age, brought together from any single country. In treating of their Bibliograply it will save repetition to consider them as one.

The leaf-impressions from Alum Bay have been known for a long time, for the first mention of them which I lave met alludes to them as already familiar to geologists. The first published reference of these remains to any group of plants was by the

1 'Foss. Flora of Great Britain,' vol. i, p. xliii.

2 'Mem. Geol. Surv.,' vol. iv, p. 586. 
Rev. W. B. Clarke," in 1839, when he described a lignitie bed as eomposed of "rclics of aquatic plants and the bark and seed-vessels of Pine." The Rev. P. B. Brodie first announeed that fossil leaves in elay were to be found to the east of Bournemouth. ${ }^{2}$ These he supposed to belong to Lauracce and Amentaeex, to Characex and other Cryptogams. In 1844 Mantell $^{3}$ notieed them, and adopts Brodie's views; again in $1847,{ }^{4}$ he mentioned the oceurrenee at Bournemouth "of the samc spceies of plants as those found in Alum Bay." In 1849 Prestwieh 'fixed the relative position of the Bournemouth and Alum Bay leaf-beds, and recorded the finding of leaves, although of few speeies, west of Bournemonth. In 1850 Dixon's 'Geology of Sussex' appeared, in whieh a few plant-remains were figured from Braeklesham. Two were identified as Lycopodites squamatus and Cucumites variabilis, and the third was ealled Piniles Dixoni. There were also figured some very beautiful seetions of palm-stems picked up on the beach near Worthing and Shoreham. ${ }^{6}$

In 1851 Mantell, ${ }^{7}$ who was evidently himself aequainted with the Bournemouth leaf-beds, introdueed some notes on the "Foliage of Dicotyledonous 'Trees," from "thin layers of sandy clay in the cliffs west of Bournemoutl." All the leaves were dieotyledonous, and appeared to him to have been shed. Many he still eonsidered referable to Lauraceæ and Amentaceæ, and some he referred more specially to species of Willow, Poplar, and Laburnum. In another of his works ${ }^{8}$ we find a foot-note stating that, while the vegetable remains from the Isle of Shcppey are tropical in eharacter, those from Bournemouth, Alum Bay, and Newhaven, are of a temperate elimate, e.g., Nerium and Platanus, whence Edward Forbes inferred that in the former ease they were transported from distant lands by eurrents, and the latter were the true flora of the country.

In 1853 the Rev. P. B. Brodie ${ }^{9}$ noticed the occurrenee, at Corfe, of elytra of Coleopterous Inseets belonging to the families Curculionidx and Buprestidæ. A Date-palm and a speeies of Willow are also mentioned by him as having been obtained from the neighbourhood of Corfe; and he further states that a larger number of plants had been proeured in different parts of the series, appearing to belong to distinet natural orders. In 1854, aecording to Prestwieh, ${ }^{10}$ there were only three speeics of plants

1 'Mag. Nat. Hist.,' ser. ii, vol. iii, p. 438.

2 'Proc. Geol. Soc.,' vol. iii, p. 592.

3 'Medals of Creation,' vol. i, p. 193.

4 'Geol. Isle of Wight,' p. 169.

5 'Quart. Journ. Geol. Soc.,' vol. v, p. 43.

${ }_{6}$ The exact age of the rolled palm-wood is unknown, but it may be derived from Eocene below the London Clay.

7 'Geological Excursion round the Isle of Wight,' 2nd edition, Supplement.

8 'Fossils of the British Museum,' 1851, p. 51.

9 ‘Quart. Journ. Geol. Soc.,' vol. ix, p. 53.

10 'Quart. Journ. Geol. Soc.,' vol. x, p. 75. 
known in the Braeklesham flora. In the same year the elytra of four Beetles were figured by Westwood $;^{1}$ and Ruegg. ${ }^{2}$ mentions that the delieate leaf-impressions from the Dorsetshire pipe-elays belong for the most part to the natural order Salieineæ.

Nothing further was published until 1856, when the first attempt to give a general deseription of these floras, and to determine their speeies, was made by De-la-Harpe. ${ }^{3}$ Some 300 speeimens were got together from all the known eolleetions. From Alum Bay alone 200 were examined, all being either in the possession of the Geologieal Survey, Bowerbank, or Prestwieh. Of the Alum Bay flora 48 speeies were reeognised and 43 determined; 13 of these were said to be eommon to Bournemouth, 7 to Corfe Castle, 3 to Reading, and 26 peculiar to itself. A Maple and a Poplar were abundant in individuals. Figs and Laurels are represented by many speeies; the largest leaf is that of a Walnut. 'Two or three Banksias are eommon; but the most abundant in speeies and individuals are the Leguminosæ, whieh, he remarks, are absent at Bournemouth and Corfe.

For the Bournemouth Flora there was only a small number of speeimens in the Geologieal Survey Museum. 'Twenty-two speeies were, however, reeognised, 13 eommon to Alum Bay, 5 to Corfe, 1 to Counter Hill; all were dieotyledonous, exeept a small parasitie Fungus. The speeies in the same Musenm obtained at Corfe were identified, 7 as eommon to Alum Bay, and 5 to Bournemouth. De-la-Harpe enters into eomparisons of the floras, and bases upon them eonelusions which were, perhaps, justified by the imperfeet materials then at his eommand.

In $1859 \mathrm{Heer}^{4}{ }^{4}$ supposing the age of the Alum Bay leaf-bed to be the same as that of the Barton Clay, alludes to them as "Upper Eoeene." His trained pereeption led him to deteet the eonneetion between the Alum Bay and the Sheppey floras. The leaves of Apeibopsis, De-la-Harpe, are, he says, "perhaps from the same tree whose fruit Bowerbank named Cucumites variabilis." At Bournemouth leaves are found, apparently of Cupania, whieh may, perhaps, be eombined with the fruit of Cupanoides." The flora more partieularly resembles that of Monte Bolea, 9 speeies out of 40 being eonsidered to be eommon to both.

In 1862 the Geologieal Survey published a 'Memoir on the Isle of Wight,' in whieh all the then determined fossil leaves and fruits from Alum Bay were tabulated (pp. 121, \&e.) and 21 speeies figured (pls. 5, 6, and 7), and deseribed by De-la-Harpe (pp. 109, \&e.). This, the most important work hitherto brought out on the subjeet, was left in the hands of De-la-Harpe, Salter laving no responsibility in this portion of the work. In the first introduetory sentenee by Salter the fossil floras of Bournemouth, Corfe, and

1 'Quart. Journ. Geol. Soc.,' vol. x, p. 381, pl. xvi, figs. 34, 35; also pl. xiv, figs. 4 and 8, see 'Geol. Mag.,' vol. vii, p. 348 .

2 'Journ. Roy. Agric. Soc.,' vol. xv, p. 394.

3 ' Bull. de la Société Vaudoise des Sciences Naturelles,' 1856.

4 'Flora Tertiaria Helvetiæ,' vol. iii, p. 314.

5 'Flor. Tert. Helv.,' vol. iii, p. 314. 
Alum Bay, are said to be "idcntical," and a little further on these places are said to be "on exactly the same horizon," although their relative positions had long previously becn pointed out by Prestwich and others. The determinations and correlations are very incorrect, probably from the specimens being mixed, since of 2.2 species from Bournemouth, 13 are said to be identical with those of Alum Bay; but we now know that none of the characteristic forms are common to both horizons. Palms are said to bc met with only at Corfe; yet two species are included in the list of fossils from Alum. Bay, in the body of the work, at p. 4.. 'This momoir does not include any species not published in De-la-Harpe's previous work; an addendum contains a rough list from Heer of the genera found in the Miocene of Oeningen, which has no apparent connection with the subject.

In 1865 W. S. Mitchell, ${ }^{1}$ who for some time previously had been working at the Lower and Middle Bagshot Beds, figured a specics of Porana, which he provisionally named $P$. Vectensis. He also noticed various new leaves, to which, however, he declined to attach either generic or specific names. In $1866^{2}$ he again announced the discovery of further leaf-forms at Alum Bay, without offering any opinion as to the number of species obtained. Some 470 specimens had been collected, and drawings of some were exhibited to the British Association. ${ }^{3}$ Two years later G. Maw ${ }^{4}$ expressed the opinion that the Porance of Mitchell, and another flower-like form from Studland, resemble Kydia more than Porana. In $1869^{5}$ A. Wanklyn described fragments of a Gleichenia from Bournemouth, for which he proposed a new genus and two species. In 1870 Mansell-Pleydell ${ }^{6}$ noticcd the occurrence of plant-remains at Alum. Bay, Studland, \&c., especially mentioning Gleichenia and Sabal.

From this time little has been written except the few brief notices in which I have quite recently called attention to the unexpected extent of the Bagshot floras of Hampshire and Dorsetshire. These will be found in the 'Reports of Conferences held in connection with the Loan Collection of Scientific Apparatus in 1876, Section of Physical Geography, \&c.,' p. 412 ; in the text of a lecture given in the latter part of 1876, at the South Kensington Museum ; in a paper read before the "Geologists' Association," January 5th, 1877, published in the fifth volume of their "Proceedings;' in subsequent papers in 'Nature, ${ }^{8}$ and in an article in the 'Popular Science Review' for' July, 1878.

In Prof. Rupert Jones's second edition of Dixon's 'Geology of Sussex,' 1878, p. 162,

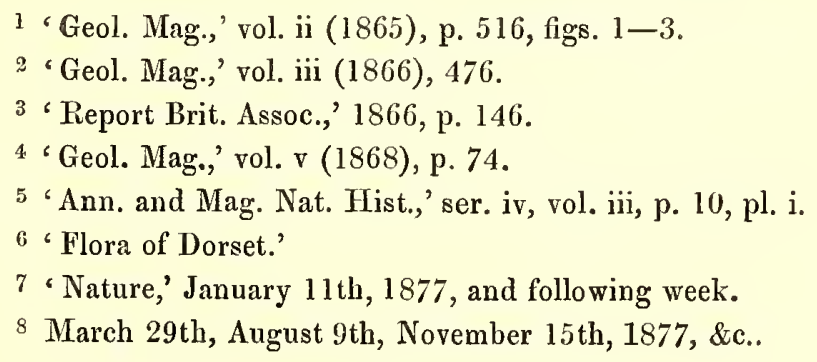


\&c., Carruthers determines the plant-remains mentioned by the original authors as Pinites Dixoni, Bowerb., Pinites Bowerbanki, Carr., fragment of a Coniferous twig, Cedroxylon IVorthingense, Carr., Palmacites Dixoni, Carr., Palmacites constrictus, Carr, Palmacites oblongus, Carr., Carpolites Dixoni, Carr., and Dicotyledonous Wood.

§ 1. The Lower-Bagshot Flora.-Next to that from Sheppey this is the most widely known of the English Eoeene Floras. It has attraeted eonsiderable attention, partly perhaps on aecount of the beds being conspicuously exposed and easily aceessible at Alum Bay. In the pipe-clay bed which oeeurs there we have an exceedingly wellpreserved and beautiful, as well as extensive, flora. 'The leaves, almost always dctached, are flat and smooth, and appear to have belonged principally to deeiduous forest-trees. The speeies are not abundant, eompared with the number of specimens. The distinetive charaeter of the flora is due to the size and variety of the leaves aseribed to the genus Fieus and to the Leguminosæ, in a seareely less degree to a deeply eleft palmate Aralia, a trilobed leaf resembling Liquidambar, a deeply serrate Banksia, and otlier leaves rcferred to Comptonia, Dryandra, and Myriea. Few, if any, of these have been found in the Middle Bagshot division at Bournemouth. The inferenee that the Studland beds were of the same geologieal age as those of Alum Bay has been confirmed, many of the charaeteristie Alum Bay leaves having lately been found there, including the Aralia and Liquidambar. T'he Studland flora, lowever, lias a somewhat different eharaeter; for although all the dieotyledons are identical, they are in the minority, and their leaves are bent and mingled with masses of broken fronds of large Fan-palms and Ferns; whilst many Inseet wing-eases and Shells have been met with implying, as I bclieve, grcater proximity to land. Mitehell informs me that leaves in good preservation were formerly found in the elay-pits at Branksea Island, of this age, but no reeord of their forms is preserved. Splendid spceimens used to be obtained abundantly from the Corfe pits, but time and dust have so obliterated the smaller leaves that have been preserved as to render them valueless for purposes of identifieation. Fragments of Fan-palms in various Museums, and some large-lobed leaves in the Museum at Oxford, are almost the only well-marked speeimens still remaining. Repeated seareh in these pits of late years has only brought to light a few leaves of simple form, without distinet venation. No reeord of the forms of the leaves discovered in pipe-clay at Newbury exists as far as I know. ${ }^{1}$ The Lower-Bagshot flora appears to possess sueh very distinctive characters that we may be enabled safcly to compare it with European fossil floras, and so to fix their horizon.

§ 2. The Mrddle-Bagshot Flora.-This appears to be far more extensive and more varied than that of the Lower Bagshot beds, although less known, colleeting having been hitherto confined to the cliffs close to Bournemouth. Leaves, flowers, and

\footnotetext{
1 'Memoirs of the Geol. Survey,' vol. iv, p. 312.
} 
fruits occur there in very small basins; to the number of thcse which have now been explored, and to the fact that each basin contains a large proportion of plants peculiar to itself, are due the extent and riehness of the material at our disposal. The western portion of the cliff-section presents us with the older beds, and these contain principally leaves of dicotyledonous forest-trees; the central area, adjoining Bournemouth Pier, abounds in Palms, Ferns, \&c.; while to the east we see marsh- or swamp-vegetation, and finally fruits, seeds, and branches, which havc been floated out to sea. Commencing from the west, we find, at less than half a mile from the rise of the eliffs, some small patches of clay with a few leaves peculiar to them; the first flora of importance, however, is contained prineipally in two basins. The more westerly was the richer of the two, but is now inaccessible, if not completely lost, from a heavy landslip. It was characterised by the number of brauches with leaves attached, that it eontained. 'The trees were mainly dicotyledonous, and, I believe, largely evergreen. Palms have not been observed, but a elimbing Lygodium is prevalent. A large pinnatifid leaf, resembling Stenocarpus, is confined to this bed. The occurrence of leaves attached to branches, of Insect remains, and of a feather, seems to indicate proximity to the shore. The second basin contains scarcely anytling but quantities of singlc and very perfect leaves, resembling those of a large Hornbeam or Beech, which are spread in layers. The next bed is a little to the east, and contains a great variety of small Willow-like leaves, with entire and serrate margins. It is remarkable that, wherc any of the species found in other beds are met with in this, they are seen to be stmnted or dwarfed. My interpretation of these facts is that the western beds present a comparatively upland flora, the leaves found in the first basins having been shed from luxuriant forests, and those in the latter from trees or bushes which grew in a more barren tract.

The next beds are in the inmediate neighbourhood of Bournemouth. Approaehing from the west, the first leaf-bed is a mass of compact dark clay. 'The uppermost layers contain some indistinct leaf-impressions, then we meet with large pinnate lcaves of Palms, crossing each other in all directions $;^{1}$ and under these a bed of leaves, the prevailing form being a Myriea, not elsewhere met with at Bournemouth. Thle next bed contains many especially characteristic plants; among them being the Glcichenia, whose fronds occupy a layer by themselves, large pinnate leaves of a Palm, which appear to me to resemble Iriartea more than any other genus, and a Castanea-like leaf (Godoya?), the only one met with at Bournemonth. The sneceeding beds under the Coastguard Station consist of seven or eight layers, separated from each other by coarse quartz grit, and each characterised by a group of leaves more or less peculiar to it. Scveral of the rarer Ferns, both pinnate and palnate leaves of Palms, and some of the most important dicotyledons, were obtained from them. One layer contains hardly anything but leaves of a small Ficus. The uppermost bed, a dark-black clay, is full of the pinnæ of Osmonda

1 A portion of one extracted measured four feet in length by three feet in breadth. 
lignitum, Cactus spines, and branchlets of a Sequoia-like Conifer, and recalls most forcibly, by its aspect, by the identity of its fossils, and by the manner of their occurrence, some of the beds at Bovey-Tracey. We scem to have in these central beds the remains of a luxuriant and tropical valley vegetation.

Beyond the Pier a bed contains Ferns, Aroids, Fan-palms, and a Eucalyptus, and with these a Sequoia-like Conifer, which from the complete absence everywhere of cones, the similarity of foliage, and the association of plants, may, perhaps, be referred to the swamp-loving Podocarpus or Dacrydium. The last fresh-water beds met with contain the remarkable forms referred to the Polypodiacex. They are associated with other Ferns, Rushes, and the Conifer already mentioned, and indicate a swamp-vegetation. Thus, by the plants may be traced the change from hill to valley and from valley to marsh.

In the Marine Beds are found numerous fruits, sceds, fragments of Conifers, Cactus, \&c. The fruits and seeds, althongh comparatively few in number, are a valuable discovcry, being from a higher horizon than the leaf-patches. 'They appear, like those from Bracklesham, to be related to the fruits from Sheppey, which are found in the London Clay, and thercfore below the leaves. About sixteen kinds have bcen collected, including, it is supposed, Nipadites, Hightea, Cucumites, and Petrophiloides, sufficient to establish that no great break took place in the flora as a whole. The assistance of the Sheppey fruits may thus be important in determining the genera of the Bagshot leaves and flowers; for, even with a slight connection established, we should, in cases where leaves might be referred to differcnt genera, get data for selecting a particular genus from the Sheppcy fruits. These determinations may thus have a value which botanists refuse to them when based on leaves alone.

The Flora of Bovey-Tracey.-It may appear strange to find the flora of Bovey-Tracey, thought to be typically Miocene, included in that of the Middle Bagshot. It is, however, pcrfectly clear to me that the Bovey-Tracey beds are on the same horizon as those at Bournemouth, from which they are some eighty miles distant. Even in this first section upon Ferns it will be seen that there are elements common to both, for two of the three are common to Bournemoutlı; and, while one is equally rare at both places, another is equally abundant at both, and found under preciscly similar conditions. The detached pinnæ of Osmunda lignitum are found in blackish shaly clay, spread in layers mingled with Cactus spines and Sequoia, exactly as they are at Bournemouth; and so identical are they in appearance that, were the specimens mixed, it would be impossible to tell which bclonged to either locality. The third Fern found at Bovey is a common Eocene form. Of other plants, the Cactus (Patmacites Damonorops, Heer) is found abundantly in certain beds at Bournemouth and Bovey, and scarcely anywhere else. The fruits are so similar that handfuls of Anona, for instance, from each place, if once mixed, could not again be scparated. The Cimnamons of Bovey, thought to be so characteristic of the Miocene, are most abundant everywhere at Bournemouth. The Oaks, the Laurels, 
the Figs, in fact nearly, if not quite all the Dicotyledonous leaves arc identical, so that the Bournemouth flora itself must be Miocene if that of Bovey be Miocene. Were a minority of the plants, instead of a majority, common to both, it would not be surprising, seeing that neighbouring patches at Bournemouth differ much more considerably in their contents from each other than does the Bovey-Tracey flora, as a whole, from that of Bournemouth; and we could therefore hardly have expected to find, especially taking into considcration the variety and richness of the Middle-Bagshot flora, an exactly similar assemblage of plants so far removed from each other and growing, perhaps, at a different level. The Bovey flora, according to Heer, bears the greatest resemblance to that of Monosque anong French Tertiary Floras, of whose Eocene age I entertain no doubt, for it is the one bearing the greatest relationship to these Middle Bagshot beds. The thrce small seeds which are supposed to link Bovey with Hempstead are, in my opinion, insignificant, and, indeed, are not confined to that section of the Eocene. The subject might be pursued further, but the progress of this work may be le ft to show the correctness of my views respecting the age of thcse beds.

When Hecr wrote ${ }^{1}$ in 1861 it nust be remembered that no Eocenc floras of any extent had been described, and scarcely any material existed for comparison, except what was of Miocene age. 'The fossil fiora of Bourncmouth was a sealed book, and many Eocenc floras on the Continent were then thought to be Miocene, so that in making comparisons error was certain to bc introduced. He was also, no doubt, influenced by the Alum-Bay plants, which hardly resemble those of Bovey, and probably somewhat by the preconceived opinions of English gcologists. It appears to mc that in the then statc of knowledge regarding these Tertiary Floras he could scarcely avoid classing the Bovey beds with the Miocene.

As the specimens from Bovey-Tracey wcre described by Heer in the "Philosophical Transactions' for 1862, it is not proposed to refer further to them cxcept in so far as the materials here worked up modify the views of the original describcr.

§3. The Upper-Bagshot Flora.-No plants whatever have been litherto described from beds of this age. I have extracted from some of the lignitcs at Barton fragments of Fir-cones and indistinct seeds, and some similar remains are to be found in the Woodwardian Museum, Cambridge.

\section{The Upper Eocene Floras.}

$\$ 1$. The Headon Flora.-No plants have been recorded from the IIcadon beds, except three species of Chara, Carpolithes ovulum, and Folliculites thalictroides. ${ }^{2}$ Palma-

1 'Phil. Transact.,' 1862, part ii, published in 1863.

2 Bristow, 'Mem. Geol. Surv.,' 1862. 
ciles Lamanonis, the woodcut of which has so frequently been introduced by Mantell in his various works, may be from this stage. Fortunately, however, Henry Keeping, in 1876, came across several fine specimens of a Feather-palm at Hordwell, now in the Woodwardian Museum. I have since seen large ironstone concretions at Hordwell traversed by similar leaves.

\$2. 'The Bembridge Frora.-Nothing but some fruits of Characeæ ${ }^{1}$ had been noticed from these beds; I have, however, seen branches of Conifers and seeds in the Bembridge Marls, at Hempstead. J. A'Court Smith has recently collected an extensive flora from Gurnet Bay, including, as he informs me, a large series of Dicotyledons, Palms, \&c.

\$3. 'The Hempstead Flora.-This flora was partially known to Lindley and Hutton in 1832, who alluded to it in the prefaee to their work, as the "Upper Freshwater Formation." Nymphæa and Zosterites are the only fossils mentioned by them as occurring in it. Edward Forbes in $1852^{2}$ scparated and described the Hempstead Beds. In $1856^{3}$ he again described them, and mentions Typha-like leaves, Taxites Parisiensis, three species of Chara, and Folliculites thatictroides as occurning in them. In 1862 a second species of Folliculites was added to the list. In 1862 $\mathrm{Heer}^{5}$ described and figured the then known Hempstead flora, ten species in all. In 1863 Ileer, in "The Lignite Formation of Bovey-Tracey,' by Pengclly and himself, described four species common to the two localities.

Although the greatcr part of this flora is composed of seeds and mere fragments of reed-like plants, beautiful leaves of Nelumbium and a small Fan-palm have been found.

\section{BRITISH EOCENE FERNS.}

THE objections to the determination of dicotyledonous leaves apply with considerably less weight to those based upon Fern fronds. Where these, however, are fragmentary and no trace of fructification is present, there is still great uncertainty, for a number of existing genera include species that have the most varied venation. It is fortunate that many of the Ferns described in the present work have been determined either from very numerous, or exeeptionally well-preserved specimens. We therefore believe that, notwitlistanding the diffieultics arising from the well-known tendency of certain Ferns to

1 'Mem. Geol. Survey, Isle of Wight,' 1862.

2 'Quart. Journ. Geol. Soc.,' vol. ix.

3 'Mem. Geol. Survey, Isle of Wight,' 1856, p. 44.

+ Bristow, 'Mem. Geol. Surv., Isle of Wight,' 1862.

5 'Quart. Journ. Geol. Soc.,' vol. xviii, p. 369. 
variation in the form of their fronds, and even in the angles and relative proximity of the venules, errors or unnceessary multiplication of species have been avoided. Nearly all the specimcus from Bournemouth, whence they were chiefly procured, seem to have * been macerated so as to discommect the pinnæ and remove the spores.

Ferms are relatively rare in British Eocenes, and yet some twenty distinct forms are described in this Monograph. The floras consist principally of deciduous dicotyledonous leaves, which, in the ordinary course of cvents, fell into the water and were tranquilly silted over. Ferns, on the other hand, would require some violence to remove them fron the place of their growth, and their preservation would consequently be exceptional, and they would be mutilated and fragmentary. This may account for their rarity.

Few as these British forms are in the number of species, they nevcrtheless form the largest and most important series of Eoeene, even of Tertary l'erns, yet described from any one group of beds.

Although our knowledge of the Ferns which existed in Tertiary times is still most imperfect, yet we find that nearly all of them have allied living representatives, although none of these now live in the British Isles. So close, in fact, are the resemblances in many cases, that it is difficult to avoid the belief that they are the more or less direct descendants of the fossil forms; indeed, some Continental authors, think that in the Miocenes of Switzerland the directly intcrvening forms can be traced.

A few of the genera here described belong to groups which have not previously been found fossil; but many of them are Eocene forms already described. It is interesting to find that some of these, like a few living species, ranged synchronously over both hemispheres, as a few are also found fossil in North America.

One of the most remarkable, and a very abundant form, is a Chrysodium, which ranges from the Alum-Bay beds at Studland, through the Lower-Bournemouth series, into the overlying marine beds, and has a no less wide range upon the Continent. The Polypodiea with reticulated venation are represented by at last three speeies; numbers of specimens of each having been obtained. Their venation is somewhat abnormal, in one instance approaching so nearly to that of dicotyledons as to leave considerable doubt in my mind as to its determination. The Pleridea are represented by several species, the most abundant of which is closely allied to many Eocene and Miocene forms already known. Another, of which we have only a fragment, is related to a group with retieulated venation now living in Polynesia. A third is liardly distinguishable from the widely distributed Miocene $P$. QEningensis. A unique specimen is doubtfully referred to the Asplenacea. The Aspidiacea have three representatives, one of whieh possesses a new type of venation, somewhat resembling that of certain dicotyledons, and has been plaeed by Ettingshausen in a new genus. The others are referred to Phegopteris, and resembles living forms. Gleichenia, well known in Cretaeeous times, has only been met with in admittedly Eoeene strata at Bournemouth, where it is represented by a trailing or climbing form, of most loeal and limited distribution. The 
Schizeacea are represented by a Lygodium allied to the recent L. palmatum, and identical with a species from the Eocene Lignitic Series of America. In this Fern the fertile fronds have also been met with. A species of Aneimia is very abundant and beautifully preserved at Bourncmouth, and is also common to the Eocenes of America and Sézanne, and possibly Aix-la-Chapelle. The most prevalent form, however, is Osmunda lignitum, which is equally abundant at Bovey-Tracey, and of which O. Dowkeri, Carr., may possibly be the stem. Of the other Ferns figured, one, if not two, certainly belongs to Adiantum; and there are others upon which no detcrmination can be hazarded.

The Ferns seem to throw some light upon the physical condition and gradual depression of the land in the Eocene period. At Boumemonth the lower beds, met with towards Poole, are supposed to contain a wooded and more or less hillside flora, and Ferns are there represented only by a climbing Lygodium. In the beds further east, near the Pier, which contain a more luxuriant vegetation, we find the dclicate Gleichenia, both species of Phegopteris, and Osmunda. These, I believe, required a warm, moist, shady situation. We next find the large Chrysodium, Osmunda, Meniplyyllum, and Pteris, mingled with masses of Aroids, \&c., which would require a still more moist habitat. Finally, in the most castern and newest beds of the freshwater series, wc meet with masses of Polypodiea, which probably grew at the sea-level in company with a decidedly swamp vegetation.

Of all the Ferns described, only four wcre previously known as British, and two of these were supposed to be from the Miocene. Three were known from the American Eoccne, four from the Aquitanjan and Tongrian stages of Western Europe, and one from Sézanne; the rest are new. In addition to these, there are several other Ferns, which are too indistinct to be figured.

Von Ettingshausen, in his work on Tertiary plants, has found it necessary to invent a distinct terminology for Ferns. ${ }^{1}$ His explanation of the types of venation, and the terms he distinguishes them by, so far as he employs them in the present work, will be useful here.

"The simplest venation in Fcrns is the IIyphopteris (fig. 1), in which each division of the frond is traversed by only one vein.

"When the veins, and consequently also the divisions of the frond, are arranged in a compact pinnate or pectinate order, then the IIyphopteris type becomes the Craspedopteris (fig. 2). In this case the rachis may be regarded as the midrib or primary vein, and the midribs as secondary veins. This applies more particularly to the Craspedopteris vera, where the secondary veins are mostly connected by parenchyma. When the veins are disconnected, except at their base, it becomes Craspedopteris Ctenodes, e.g. Polybotrya Lechleriana, Mett.; Ett., 'Farnkr.,' Pl. xiii, figs. 5, 6, \&c.

\footnotetext{
1 'Die Farnkräuten der Jeztwelt,' Vienna, 1865.
} 
"In most Ferns, however, the divisions of the frond are traversed by several or many veins. When they are forked primary veins, diverging from each other in a radiate manner, and equal, or the central one more prominent, the venation is Cyclopteris (fig. 3). This is divided into several types, of which I will explain the $C$. simplex aqualis, the $C$. simplex inaqualis, and the $C$. composita. In the first the primary veins are symmetrically disposed, forming only forked branches (ex. Adiantum); in the second the primary veins are nearly all on one side of the division, or unsynımetrically dispersed; and in the last the primary veins send out secondary ones, as in Lygodium.

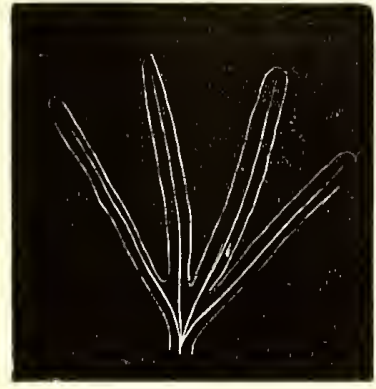

Fig. 1.-Hyphopteris.

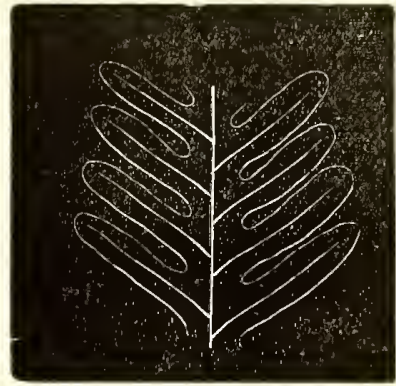

Fici. 2.-Craspedopteris.

"In ail other kinds of venation of Ferns, each ultimate division has only onc prinary vein (the midrib or costa) from which the secondary ones spring, and the latter frequently give rise to ternary veins.

"The primary vein rarely reaches the apex of the pinnule in Neuropteris (fig. 4), but disappears in a number of forked branches, and the secondary veins are given off from it at very sharp angles, diverging in curves towards the margin, so that their marginal branches constantly form more obtuse angles with the primary vein than their stems. Among the

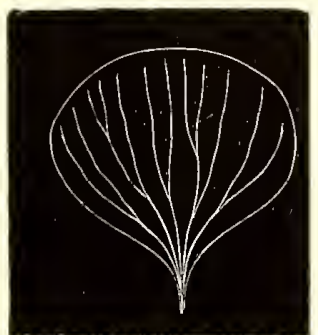

Fig. 3.-Cy clopteris.

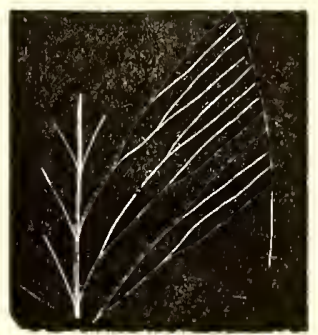

FIG. 4.-Neuropteris.

types of this kind of venation we notice the Neuropteris vera; here the midrib is invariably dissolved, and usually at an appreciable distance from the apes, and the dichotomously branched secondary veins diverge very much. In $N$. acrostichacea the primary vein is prolonged almost close to the apex, or even reaches it; and the secondary veins are only once or twice forked, and are less divergent (ex. Pteris cocanica, $\& c$.$) .$ 
"'This last type comes near that of T'eniopteris (fig. 7), in which, however, the midrib is very much elongated, the secondary veins exceedingly numerous, given off at right, or not very acute angles, and never divergent, but either convergent (towards the midrib) or rectilineal.

"In the Alethopteris type (fig. 5) the midrib is slender, and gives off short rectilineal or slightly convergently curved secondary veins at acute angles; ternary veins are wanting, or only proceed from the lowest secondary ones, and only on one side (of the pinnule).

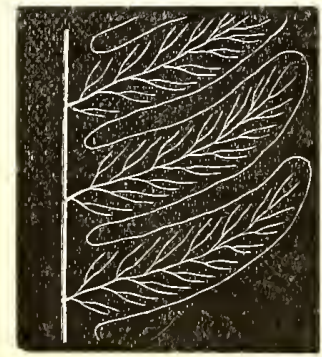

FIG. 5.-Alethopteris.

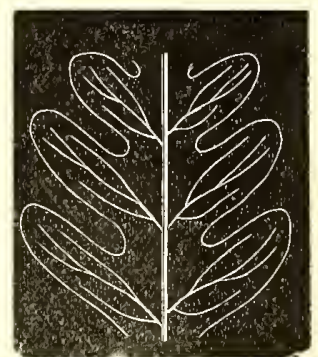

FIG. 6.-Pecopteris.

"In the Pecopteris type (fig. 6) the undivided or forked secondary veins spring from the midrib, which is distinctly continued to the apex, at slightly acute angles, and send out ternary veins (ex. Gleichenia Hantonensis and Osmunda lignitum).

"Whereas in the foregoing types of venation all the veins are free, in the following some or all of them anastomose with each other. Those of the Goniopteris type (fig. 8) all anastomose, or at least the inner ternary veins, and remain undivided. The two anastomosing veins blend in one called the ray, which runs through in the Goxiopteris-

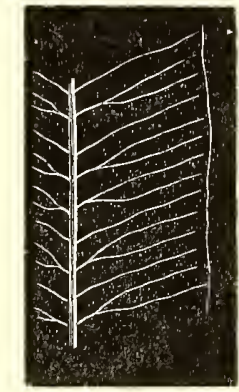

FIG. 7.-Tæniopteris.

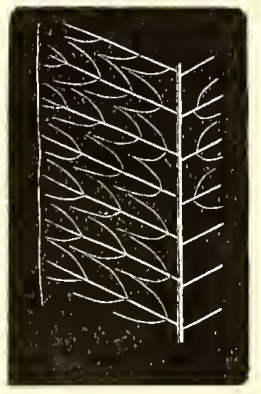

Fig. 8.- Goniopteris.

Aspidii type, that is to say, it extends to the point of mion of the next pair, whilst in the Goniopteris Meniscii type (Phegopteris pra-cuspidata; Pl. IV, fig. 9) they terminate before reaching the union. All the ternary veins are united in the latter type, but in that of $G$. Aspidii (Pliegopteris Bunburii, Pl. V) some of them are free.

"When the ternary veins form a network in which there is a row of larger meshes on either side of the midrib or secondary veins, we have the Dictyopteris type. In this either all the veins are connected in a network (D. simplex), or the secondary ones are 
looped, curved, or marginal, and only the ternary one netted (D. composita). The secondary and ternary veins are remarkably shortened in the former, and scarcely, or not distinctly, separated from each other. The meshes of the network enclose free venules or not, and are accordingly $D$. appendiculata or D. exappendiculata (Chrysodium Lanzaanum).

"Finally, there are the Phlebodium (fig. 9) and Drynaria (fig. 10) types of venation belonging to the group with anastomosing veins. In the former the very much abbreviated secondary veins form, by a peculiar anastomosis of their forked branches, a prominent row of larger long meshes on each side of the midrib, and several rows of loops. In the Drynaria type the anastomosing ternary veins are given off in a pinnate manner from both sides of

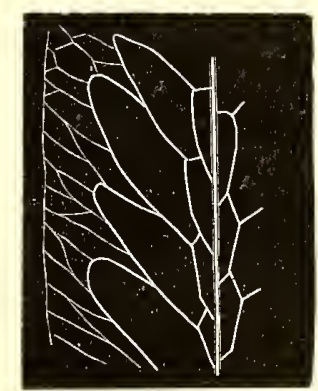

Frg. 9.-Phlebodium.

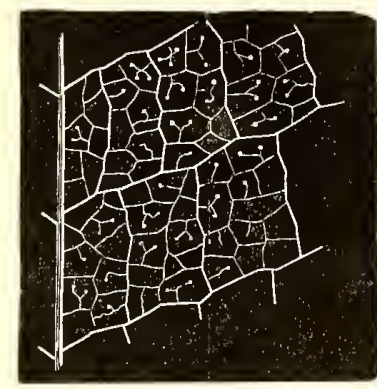

Fig. 10.-Drynaria.

the elongated secondary ones, which are strongly curved or looped. The rays or appendages within the ternary meshes anastomose in such a manner as to form a network resembling the venation of dicotyledonous leaves. The meshes usually enclose free venules. When the ternary segments are regularly rhomboid or elongated, it is the Drynaria regularis type; when these segments are indistinctly outlined and of irregular shape, they belong to the D. irregularis type (Glossuchlamys transmutans, PI. III, fig. 3), and when the secondary veins form neither curves nor loops, but terminate in the margin, combining with the marginal ones, they compose the Drynaria composita type, a type at present confined to the fossil genus Meniphyllum." 


\title{
CRYPTOGAME.
}

\author{
Order.-FILICES. \\ SUB-ORDER.-POLYPODIACE $A$.
}

(A.) Acrostichacea.

Chrysodium Lanzanum (Visiani). Plate I and Plate II, figs. 1-4.

Fortisia Lanzeana, Visiani. Piante fossili della Dalmazia, p. 1 J, pl. 1, fig. 8; pl. 2, figs. 1 and 5 .

Ch. fronde coriacea pinnata, pinnis lanceolatis vel oblongo-lanceolatis, acuminatis, margine undulatis vel integerrimis, basi sessitibus, mediis et inferioribus semi-amplexicaulibus, subdecurrentibus, superioribus attenuatis; nervatione Dictyopteridis simplicis exappendiculate; nervo primario pervalido, rigido, prominente; nervis secundariis angulis acutis variis egredientibus, congestis, abbreviatis, dictyodromis; maculis oblongis, prominentibus, pluriseriatis.

Lower Bagshot, Studland; Middle Bagshot, Bournemouth; Upper Eocene, Hordwell.

The remains are those of a large Fern closely allied to the existing wide-spread tropical Chrysodium vulgare, Fée. The thick carbonised substance of the frond figured in Pl. I indicates its former coriaceous texture. The pinnæ are lanceolate, and are so closely seated on the rachis, which is $8 \mathrm{~mm}$. in diareter, that their margins overlap. They seem to have varied in the form of the base from cuneate to semi-amplexicaul, according to their position on the rachis, and to the size and development of the frond: thus, those represented in Pl. I have a broadly amplexicaul, almost decurrent base, and are from the middle of a frond; whilst in Pl. II, fig. 2, a pinna is seen with an almost acute base, and is therefore supposed to have been derived from the upper part of a frond. A somewhat similar variation, but in a much less degree, is seen in the bases of the pinnæ of Ch. vulgare, which are, however, never amplexicaul, but always stipitate. The apex is pointed; the margin undulate. In venation it also approaches Ch. vulgare, differing slightly only in the greater divergence of the angles at which the secondary veins start, and in the greater diversity of form presented by the meshes of the network. 
Numerous short, contiguous, intricately anastomosing, fine veins proceed from a prominent midrib, at angles more acute on the less developed pinnæ towards the apex of the frond (PI. II, fig. 2), than those of the middle and base. 'The limits of the divergence observed in the angles are $20^{\circ}$ and $60^{\circ}$. The short secondary veins are as close together as in $\mathrm{Cl}$. vulgare. In length and shape the meshes vary from rectangular to narrowlanceolate or linear ; sometimes, as Pl. II, fig. 4, from Studland, not anastomosing throughout their entire length. In Ch. vulgare the range of variation, in this as in other respects, is more circumscribed.

The fossil, while closely resembling the recent Ch. vulgare, seems to have been more variable in its growth, and differed principally in the more amplexieanl attachment of the pinnæ.

Chrysodium Lanzcenum was described in 1858 by Visiani from the Eocene of Monte Promina as Fortisia, a genus which he founded for this and a closely allied species. In 1877 Saporta announced the discovery of a Chrysodium from the Aquitanian

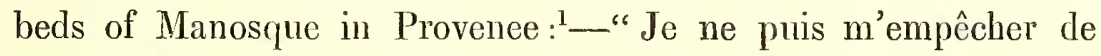
signaler * * * un très beau Clirysodium, genre d'aerostichées, dont une espèce encore inédite, recueillie aux cnvirons de Manosque, se rattache directement aux formes les plus nettement tropicales." This Chrysodium from Manosque, of which numerous pinna are preserved on the surface of a large slab, is nearly allied, Saporta informs me, like the Bournemouth plant, to Cl. vulgare; but the pinnæ are narrower, morc lanceolatc, and with a more acute and attennated apex, and the whole plant appears to have been more slender; resembling in these respects the Hordwell specimens. He therefore thinks that the two can hardly be identified as a single speeies. It is remarkable that it was there associated with Lastraa Stiriaca, Osmunda lignitum, and Lygodium Gaudini, as at Bournemouth and Bovey-Tracey, and that with these also oeeur at Manosque species of Pteris allied to those of Bournemouth, Pteris pennaformis and $P$. uroplyylla, the latter only a variety of $P$. Ciningensis. There is thus seen to be a considcrable resemblance in the Ferns from the two localities, whieh are supposed to differ in age sufficiently to account for the slightly varying specific characters. Remains of

1 'La Nature, Revue des Sciences,' 5 année, No. 224, p. 245, 15 th September, 1877.
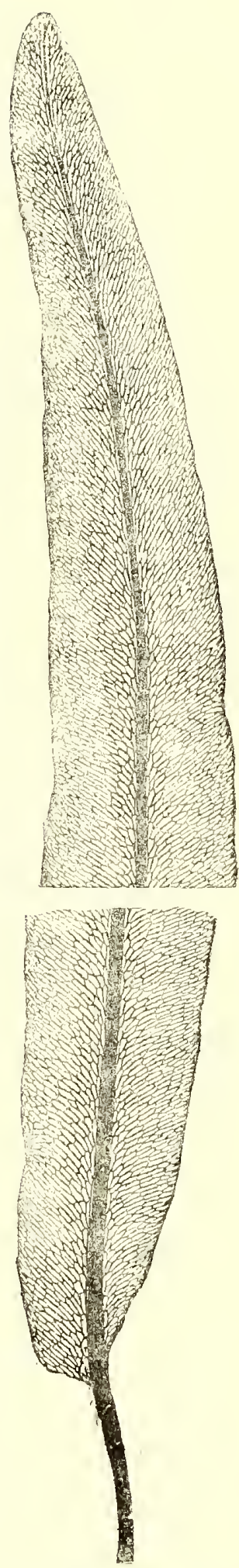

FIG. 11.-Chrysodium vulgare. 
Chrysodium have quite recently been met with by Saporta in the Gypsum of Aix, from whieh more than 300 forms of plants have been collected. This undescribed species has been minutely compared by Saporta with specimens of the Bournemouth Chrysodium, and he pronounces them to be specifically the same, although the Aix specimens are somewhat smaller. The venation is shown by Saporta's drawings to be identical.

The distribution of Ch. Lanzaanum is consequently extended in Europe to the Middle Eocene of Monte Promina, the Upper Eocene of Aix, and possibly to the Aquitanian of Manosque. 'The fossil species appears, therefore, to have had a wide range like the existing one; a fact in aceordance with its cxceptional range and abundanee in the English Eocenes.

The presence of Chrysucime in Europe so late as the Middle Tertiary period has thus been ascertained by numerous specimens, most of them of very recent date.

Saporta and Heer have also detected a resemblance in the Eocene species to Gymnogramma Gardneri, Lesquereux; ${ }^{1}$ indeed, Saporta had suggested this affinity ${ }^{2}$ to Lesquereux during the publication of his work. Lesquereux, however, informs me, after comparing the specimens which I forwarded to him, that, although a eonsiderable correspondenec exists, the venation in his species is much looser, and the midrib is of a different type. With referenee to Lesquerenx's determination of the American species as a Gymnogramma, Heer thinks it still doubtful, until fructification shall have been found, whether all the species belong to that genus (Dictyogramma, Fée.), or to Chrysodium.

Chrysodium Lanzaanum is locally abundant, ranging from the Lower Bagshot through the Bonrnemouth Beds, and is met with in the marine beds overlying them, and at Hordwell. It is exceedingly eommon in beds on both sides of Bournemoutl $\mathrm{Pier}$, and scareely less so in the widely separated beds at Studlaud.

De-la-Harpe mentions a small fragment in Prestwiteh's Collection, and to which he doubtfully attached the name Acrostichum, as having been obtained at Alum Bay; but its oecurrence there has not since been confirmed. Usually only torn, twisted, and detached fragments are met with; and the specimen figured in Pl. I, from a bed of black elay under the Coastguard Station at Bournemouth, is the only one in which the pinnæ have been found attached. No traces of fructification have yet been detected. Carruthers, being present when the larger specimen was found, immediately recognised its affinity to Chrysodium vulgare. This alliance has also been admitted by Hooker and other English botanists who have seen it, so that the correetness of the determination, due in the first instance to Carruthers, is unquestionable.

The specimens figured, Pl. II, figs. 3, 3a, 4, are from Studland; Pl. II, figs. 1, 1 $a$, $2,2 a$, and Pl. I, are from Bournemouth. In the former the secondary veins are more closely set.

1 'Tertiary Flora of America,' p. 58, pl. 4, fig. 2.

2 Op. cit., p. 58. 
(в) Polypodiea.

Geu.-Podoloma, Ett.

Filiees herbaeea, fronde simpliei, integra; sporangia nervis imposita, in soros subrotundos sparsos indusio nullo obteetos eolleeta. Nervatio Phlebodii irregularis.

Podoloma polypodioides, Eitl. and Gard. Plate III, figs. 4, 5, 6, and 9.

P. fronde submembranaeea, laneeolata vel lineari-lanecolata, integerrina, utrinque angustata; nervatione Phlebodii irregularis; nervo primario rhaehidrono, reeto, prominente, apieem versas sensim attenuato, nervis secundariis sub angulis 55- $155^{\circ}$ orientibus broehidodromis; maenlis medianis vix distinetis, inaqualibus; laqueis Phlebodii semielliptieis, incoqualibus; maculis lateralibus irregularibus minutis, 1-3 seriatis; appendiees rumerosos tenuissimos ranosos inchudentibus.

Middle Bagshot, Bournemouth.

This genus and the next approael the Dietyopteridere of the older floras and eertain reeent tropical species of Polypodium belonging to the sub-genus Plymatodes, namcly, $P$. lycopodioides, $P$. persicaricfolium, $P$. salicifolium, $P$. transparens, and $P$. hemionitideun. The leaves may be distinguished from dicotyledons, notwithstanding their superfieial resemblanee, as, independently of the remains of spore-eases, they possess the peculiar venation of this section of Polypodium.

The frond represented in Pl. III, fig. 9, offer's points of agreement in form, texture, and venation, with the barren frond of the reent Polypodium lycopodioides. 'The fossil presents the Pllebodium type of venation, modified by a less uniform shape and by the inequality of the meshes abutting on the midrib, which hardly differ from the rest. The Phlebodium loops are irregularly arranged and of unequal length and breadth. The two to three rows of marginal meshes, instead of being elliptical, are irregularly angular, and filled with numerous free and anastomosing venules (Pl. III, fig. 5). These differenees are the bases of a new type, deviating essentially from the Phlebodium appendieulatum to which P.lycopodioides belongs, and is called Phlebodium irregulare. Figs. 4 and 9 are of natural size, and show the ${ }^{\text {Frg. 12.-P. Podioidese- }}$ general form and average size of the pimne. Fig. 5, which is the base of a pinna enlarged, aceurately shows the venation in detail, and, in three places, what appear to be sori in an early stage of development, around whieh the arrangement of meshes is peeuliar. 
Fig. 6 is another fragment, further enlarged, showing small spherical markings, which require further elucidation.

Podoloma afrine, Ett. and Gard. Plate III, figs. 7, 8.

P. fronde membranaeea, laneeolala integerrima; nervatione Plllebodii irregularis; nervo primario rhachidromo, reeto, prominente, apieem versus sensim attenuato; nervis seenndariis snb angulis $30-45^{\circ}$ orientibus flexnosis broehidodromis, maeulis medianis non distinetis, laqueis Phlebodii irregularibns, inaqnalibus; maeulis lateralibus inaqnalibus, 1-2 seriatis, appendiees namerosos tennissimos ramosos ineladentilns.

Middle Bagshot, Bournemouth.

This is of a more delicate and membranous texture than the preceding, a distinguishing character in itself. In addition the secondary veins diverge at a more acute angle, are slightly sinuous, of unequal length, and at different distances apart. The median meshes which characterise the Phlebodium venation, discernible in the preceding species, are not perceptible in this, but in the magnified figure (Pl. III, fig. 8) a number of very irregular meshes are seen abutting on the midrib and taking the place of these median meshes. The Phlebodium loops, as well as all the meshes, are very irregular and unequal in form and size. 'The dots, visible without a lens, are evidently the bases of attachment of sori.

These two forms of Polypodiex are found massed together in layers in the highest freshwater beds, inmmediately underlying the marine beds. Dicotyledonous leaves seldom accompany them, but they are generally associated with torn fraginents of aroids, rushes, and conifers, and occasionally with remains of other ferns, as Osmunda, Pteris, and Clerysodium. The venation is usually well preserved and distinct, but the pinnules are always detached and the fructification removed, as if by maceration. The separating layers are so thin and brittle, and the leaves so crowded together, that it is extremely difficult to secure good specimens. The recent Polypodia with which they have been compared have long creeping rhizomes, with simple and persistent fronds, not articulated; but the fact that in the fossils the pinnules are invariably detached and in layers suggests that they belonged to annual ferns with articulated pinnæ. Their geological position and the leaves associated with them suggest that they inhabited swampy districts near the sea-shore.

Saporta, in a letter full of valuable comments, points out the resemblance which Podoloma bears to the dicotyledonous Myrsinia, Sapotace ${ }^{2}$, and the genus Bumelia. The venation, however, seems to differ more from any of these than from that of some existing Ferns. The existence of sori, besides, seems placed beyond doubt. Hecr also 
pronounces a decided opinion that they belong to the division of Polypodium with reticulate venation, and does not think that they should be generically separated unless as Polypodites. Hooker, Carruthers, and others see no reason to create a new genus for their reception. The correctness of our determination of these as Ferns may, we think, be considered as beyond reasonable doubt.

No fossil Polypodia with reticulate venation resembling these had hitherto been described.

Grossochlamis, Ett.

Filices herbacea, fronde simpliei, integra. Nervatio Diynaria irregularis.

Giossochiamys transmutans. Ett. and Gard. Plate III, fig. 3.

G. fronde submembranacea, petiolata, lanceolata, ulrinque angustata, apiee longeacuminata, margine integerrima; nervatione Diynarice irregularis, nervo primario rhaehidromo, reeto, prominente, apieem versus sensim attenuato; nervis seeundariis prominentibus cumptodromis adseendentibus, mediis sub angullis $40-50^{\circ}$, reliquis sub angulis aeatioribus orientibus; nervis tertiariis catudromis; latere caterno angulo subreeto, latere interno nlerunque angulis variis egredientibns; segmentis tertiariis vix distinetis, incqualibns, irregularibus, polygonatis; maeulis appendices plerumque liberos includentibus.

Middle Bagshot, Bournemouth.

The texture of this frond was memhranous. The apex is very elongated and narrow. The venation is somewhat like that met with in certain spccies of Polypodium, as, for examplc, Plymatodes hemionitiderm and P.transparens, and in some species of Aspidinm, as A. tifoliatum, A. macroplyyllum, A. paetryplyglhm. It deviates, however, in some essential particulars. The seeondary veins arc not sinuous, but run towards the apex of the frond in long curves, close to and sub-parallel with the margin. Their angles of departure are more acutc at apcx and base than in the middle of the frond, and in this respect the resemblance to dicotyledonous venation is great. The remaining characters of the venation are of the Drynaria irregularis type. In the catadromous loops of the ternary veins it approaches the above species of Aspidium. The species is founded upon peculiarities of venation, which consist in the tcrnary diverging from the outer side of the secondary veins at right angles, and from their inner side at varying acute and obtuse angles, and also in their relatively inconspicuous ternary segments, in proportion to the meshes and venules that are cnclosed in them. 
Saporta objeets to the referenee of this fossil to a Fern, as he eonsider's the venation to be quite unlike that of any Ferm, and to belong to a type common among dieotyledons. Heer also states that, in his opinion, "it is not a Fern, bnt a leaf of a Dieotyledon." It is found assoeiated with Podoloma.

(c) Pteridere.

Prluis bocmenca, Litt. and Gard. Plate IV, figs. 4-(i.

1'. fronde pimnata, pinnis rhachi angulo peracnto insertis, sessilibus valde elongatis, laneeolato-linearibns, acmminatis, basi obliquis, margine tenuissime serrulatis; nervatione Neuropteridis acrostichacee, nervo primario prominente, recto, apicem versus sensim attenuato; nervis secundariis sul, anyutis 10-50 orientibus, 1.5 millim. inter se distantibus, bi-vel trifurcatis, rarissime simplicibus, ramis inter se parallelis, cum nervo primario anguhm subrectum formantibus.

Middle Bagshot, Bournemouth.

'I'his species is eharaeterised by its long, narrrow pinnæ, which quit the raehis at angles of about $25^{\circ}$. 'Towards the apex of the frond they are sometimes eonfluent, deeurrent below on the raehis, as in Pl. IV, figs. 4 and 5, and apparently petiolated towards the base. The terninal pinna is the largest. 'The margins of the pinne are sinnous or altemately lobed, and very fincly toothed. 'The midrib is prominent and elongated. 'The seeondary veins are numerous and erowded, spring at acute angles, eurve outwards to the margin, and terminate in the teeth, the majority of them being once, some twiee forked, and a very few undivided. 'The venation is of the type of Neuropteris aerostichaeea, which is not mommon in reeent and fossil speeies of Pleris.

$P$. eoceniea resembles very elosety a number of living speeies of Pteris, as $P$. crenata, $P$. eretica, \&c. It also resembles the Aquitanian speeies, P. pennaformis, Heer, ${ }^{1}$ but may be distinguished by the secondary veins, whieh are less erowded and more generally. forked, and by the margin, whieh is lobed and toothed in a mueh more pronounced manner. It even more elosely resembles P. Parsehtuyiana, Unger, and P. Gaudini, Heer, but differs from the former in the mueh more aente angle at which the pinne leave the rachis, whilst the latter, founded upon a single and very small fragment, has no speeific eharacter, and is possibly, as suggested by Heer himself, a fragment of $P$. pemaformis. 'The Ameriean Eoeene ${ }^{3}$ speeies $P$. subsimplex and $P$. crosa, while possessing the same

1 'Flor. 'Tert. Helv.' vol. i, p. 38, pl. xii, fig. I.

2 'Flor. 'Ter. Helv.,' vol. i, p. 39.

3 Lesq, 'Tert. flora of America,' 1878, pl. iv, pp. 52, 53. 
venation, have much broader pinnx, and $P$.pseudopennaformis has more closely and obliquely set secondary veins. Blcchnum Braunii, Ett., from Monte Promina, has similar venation and finely toothed margin; and Dr. Debey informs me that he has Ferns from Aix-la-Chapelle with a nearly related venation. Heer believes it bears a resemblance to Pecopteris Hookcri, from Bovey Traeey. Osmenda cocanica, Saporta, ${ }^{1}$ from Gelinden, strikingly resembles it, but seems to have been a larger Fern, and is considered distinct by Saporta.

Ptcris eocanica is abundant at Bournemonth in the "fern-beds," where it is assoeiated with the Polypodieæ. It becomes rarex westward, having but once been met with west of the pier, and then only in the lighest and remanié beds near the top of the cliff, immediately under the flagstaff. 'The specimen from this locality (Pl. IV, fig. 5) is dwarfed and attenuated. The abundance of this Fern in the newest and most casterly beds of the Bournemonth freshwater series, where it is associated with plants which required much moisture, its rarity in the slightly older beds to the west, which have a less swampy character, its dwarfed and starved appearance in the uppermost beds west of the pier, and its complete absence from all the lower beds in which, with few exceptions, the dieotyledons have been obtained, point to its habitat having been, by preference, of a swampy and marshy character, and near the sea-level. Saporta informs me that at Manosque the closely allied P. pennaformis is, like this, found associated with Chrysodium Lanzaanum and Osmunda Tignitum.

I am indebted to Mr. A. Baldry, of Bomrnemouth, for the specimen, fig. 5, Pl. IV, which we at first thought to be distinct, as the pinnæ are smaller and narrower, and the secondary veins more widely separated and less diverging. Fig. 6 (Pl. IV) represents a terminal pinma, natural size; fig. 4, the lowcr part of a frond; fig. $6 a$. enlarged venation.

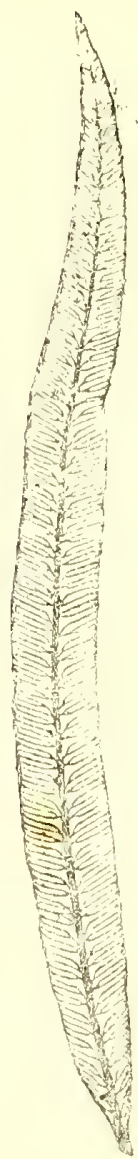

Although species of Acrosticlum, Angiopteris, Gymnogramma \&ce possess similar venation, the characters furnished by this form so closely correspond to what is met with in the recent species of Ptcris, that its reference to this genus eanuot be doubted.

\section{Pteris Bournensis, Ett. and Gard. Plate IV, fig. $\%$}

P. fronde bipinnata, pinnulis superioribus angulo acuto, reliquis angulo subrecto rhachi adnalis, basi lata sessitibus, lanccolatis, acuminalis, magine intergerrima vel levitor undulata; nervatione Alethopteridis genuina; ncrvo primario debiati, reclo, infra apicem valdc attemuto, norvis secundariis sub angulis aculis oricntibus.

\footnotetext{
1 'Flore Heersienne de Gelinden,' Saporta and Marion, 1878, pl. i, fig. !.
} 
Middle Bagshot, Bournemouth.

The specimen figured is apparently of delicate texture, and may be either the apex of a barren frond or the fragment of a pinna. The pinnules are lanceolate and gradually attenuated towards the apex, entire or slightly undulate, broadest at the base, and confluent. The uppermost pinnules are attached at acute, and the others at about right angles. The midrib is thin and tapering; the secondary veins, ten or twelve in number on each side, spring at angles of $50^{\circ}-60^{\circ}$, and are mostly forked. The venation is of the true Alethopteris type. The apparently thin texture may be due to the long maceration to which the leaf has evidently been subjected.

The specimen so closely resembles the figures of $P$. Einingensis, Unger, ${ }^{1}$ that, judging from them alone, it might be placed with it. That species, however, is of a more coriaceous texture, and appears only towards the second part of the Miocene. In connection with it Saporta has kindly communicated that he considers $P$. Einingensis, which appeared late in the Miocene, to be the forerunner of $P$. aquilina, and that the Miocene form was preceded by $P$. urophylla, and this by $P$. Aquensis and $P$. caudigera of the Aix beds. The type of $P$. aquilina is probably very ancient, and may reasonably be looked for in formations as old as the Lower Eocene. Debey thinks he has a similar type from Aix-la-Cliapelle.

This Fern, which differs essentially from the $P$. eocanica, is known from a single fragment only, met with among dicotyledons in a leaf-bed on the coast near Poole Harbour. Fig. 7 is drawn the natural size; $7 a$ shows a portion magnified.

The determination of this as Pteris is not absolutely certain in the absence of fructification, as the venation is common to many Ferns.

\section{(D) Aspleniea.}

Asplenites Pre-Allosuroides. Ett. and Gard. Plate III, figs. 1, 2.

A. fronde membranacea, tripinnata. pinnis bipinnatis patentibus, pinnulis stipitatis, ellipticis, subobtusis, tenuissime crenulatis, soris oblongis, biserialibus; nervatione Craspedopteris vera, nervo primario tenui, infra apice evanescente, nervis secundariis tenuissimis, simplicibus.

Middle Bagshot, Bournemouth.

The specimen appears to be the remains of a fertile frond, and recalls a somewhat

1 Heer, 'Flor. Tert. der Schweiz,' vol. i, p. 39, pl. xii, fig. 5. 
similar form, Asnlenites allosuroides, described by Unger, ${ }^{1}$ from Eocene beds with Cerithium margaritaceum. The frond seems tripinnate, the pinnæ spreading, and the very small pinnules shortly stipitate, elliptical, and sub-obtuse at both ends. The margin has three to five teeth. The secondary veins quit the midrib at angles of $40^{\circ}-50^{\circ}$, are simple, and terminate in the teeth, being therefore of the Craspedopteris vera type. The enlargement (Pl. III, fig. I) is after a drawing by Carruthers, who kindly assisted in the elucidation of the spccimen, which is very obscure indeed. The pinnules were of great substance, and the leaf has therefore carbonised and broken away. The rachis is zigzag.

Stur has kindly remarked upon the strong resemblance borne to our species by A. allosuroides. Unfortunately this was also determined upon a specimen in which the details were badly preserved, inasmuch as the carbonised leaf-substance from the same cause has almost entirely dropped out, and only the impression remains. It differs from $A$. pre-allosuroides in size, it being nearly double, and in the more rotundately elliptical pinnules, and as far as can be seen in their less symmetrical arrangement on the frond.

It, as well as A. allosuroides, closely resembles Pteris heteropfylla, Linn., which has coriaceous pinnules of exactly the same form, but larger. In this respect the Sotzka species connects the two. The recent Pteris scaberula has the pinnules as finely divided as the Bournemouth form.

It does not bear any close resemblance to existing species of Pellaca or Asplenium; but Gymnogramma leptoplyylla slightly resembles it. Its determination is exceedingly doubtful. Heer is of opinion that it is the fertile frond of a species of Thyrsopteris. ${ }^{2}$ It may, should better specimens be found, be necessary to unite our species to Unger's ; and this seems the more probable as a great number of Sotzka plants are associated with it at Boumemouth.

The specimen, which is unique, was found some years ago at Bournemouth, under the Coast-Guard Station, by Mr. W. S. Mitchell and Henry Keeping, and is now in the British Museum.

(E) Aspidiece.

Gen.-Meniphyldum, Ett.

Filices lerbacea, fronde pinnata, nervatio Drynaria composita.

This genus is allied to Meniscium in its marginal secondary and short ternary veins, 1 ' Fossil Flora of Sotzka,' l. c., p. 25, pl. i, fig. 1.

2 'Flor. Foss. Arctica,' iv, pl. x; Jurassic flora of Siberia. 
but it is distinguished from this and from Drynaria by the anastomosing of the ternary veins and prescnce of free velutes in the meshes. In the combination of marginal and netted venation, it presents a special type of the Dryuaria group, whieh has never been observed in recent Ferns.

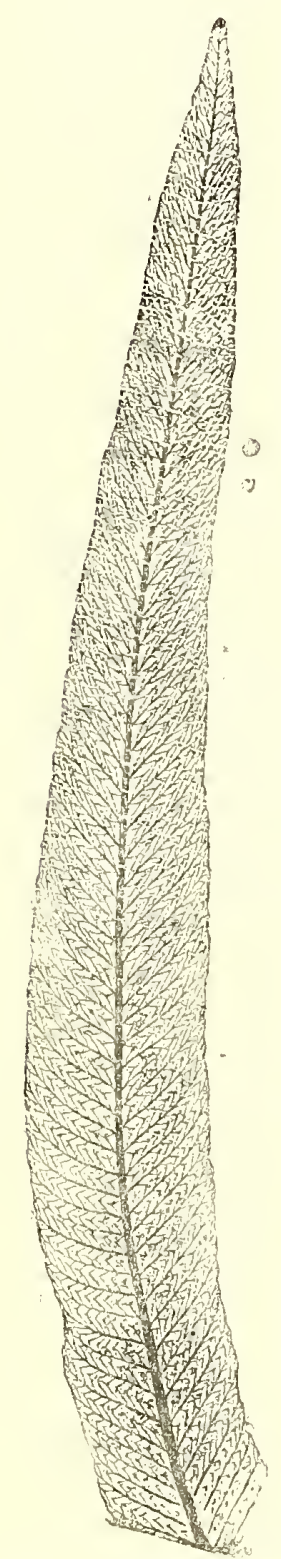

Fig. 14.-Meniscium longifolium.
Meniphylum elegans, Eul. and Gard. Pl. III, figs. 10-14.

M. pinnis subeoriaceis, stipitatis, laneeolatis, apieem versus acuminatis, basi acula inaqualibus vel obliquis, margine integerrimis; nervo primario valido prominente, scepe arenato vel flexuso, nervis secmndariis snb angulis $75-90^{\circ}$ orienlibus, numerosis, approximatis, flexuosis; nervis tertiariis angulis acutis, rarius obtusis e nervis secundariis egredientibns, abbreviatis, fexuosis; maeulis oblongoelliptieis, appendices liberos inelndentibus.

Middlc Bagshot, Bourncmontlı.

At first sight these remains appear to belong to Meniseinm, but although the shape of the pimne and the arrangement of the sceondary veius point to this affinity, the venation itself is opposed to it; for, whilst Meniseium has the Goniopteris, this has the Drynaria type. Pl. III, fig. 13, shows the venation magnified. The fronds were pinuate and probably coriaceous in texture. The pinnæ are shortly stipitate, the stalk passing into the mid-rib, which is curved or sinuous. The secondary veins are given off at rather obtuse, often almost right angles, and are numerous and closely set, thicker and less sinuous, and usually altcrnate with more slcnder and sinuous secondary veins. All extend to the margin, where they are either forked or remain undivided. T'he ternary veins form various acute and more rarely obtuse angles, are mostly vcry short and sinuous and anastomose more frequently with the neighbouring sccondary veins than together. The meshes are of irregular oblong and elliptical shape, and eontain branched free venules.

The pimnæ represented (Pl. III, figs. 10, 11, 12) were found at Bournemouth in the beds near the top of the clifi east of the Pier, associatcd with aroïls, palms, and conifers. It is sometimes found with Podoloma. Fig. 14 is from a solitary speeimen found under Branksome Watch Tower, towards Poole Harbour, associated with small oak- and willow-like leaves. The piuna secms to have been slightly shrivelled at the margin before it was imbedded, and henee the lateral marginal vein is hardly diseernible. 
This determination should be reeeived at present with some hesitation, sinee we know of no existing Fern possessing erowded secondary veins and free venules, and the venation on the other hand resembles that of eertain dicotyledons. ${ }^{1}$

Phegopteris pre-cuspidata, $k t t$. and Gard. Plate IV, figs. 8, 9.

Ph. fronde pinnata, pinnis lanceolato-linearibus, elongatis, crenato-serratis; nervatione Goniopteridis Meniscii, nervo primario prominente, recto; nervis secundariis sub angulis $60-75^{\circ}$ orientibus, numerosis, tenuibus, simplicibus, flexnosis; nervis tertiariis utrinque 4-6 e nervis secundariis angulis acutioribus egredientibus, anastomosantibus, catadromis; radiis interruptis vel obliteratis.

Middle Bagshot, Bournemouth.

The pinnæ are linear-lanceolate, obtusely serrate, with the venation of Goniopteris, in which all the ternary veins anastomose. It is referred to the Goniopteris Meniscii type, beeause the rays are interrupted and not eontinuous. It is probably a Phegopteris, and, indeed, differs only from $P$. cuspidata, Mett., in the following unimportant partieulars: the marginal teeth are rather more obtuse or erenate; the midrib is prominent yet less thiek; the seeondary veins are sinuous instead of only eurved upwards near the margin, less elose, and at more aeute angles; the lower ternary veins have a distinctly catadromous origin; the ramifieations are usually very short, interrupted or abortive instead of always present. Its similarity to Gymnogramma villosa of Brazil is also striking.

There are also eertain resemblanees between this and the Miocene forms Phegopteris Helvetica (Lastraa), Heer, ${ }^{8}$ Ph. polypodioides, ${ }^{3}$ and Ph. Stiriaca, ${ }^{4}$ also abundant at Bovey Tracey.

Heer would unite it with Ph. Bunburyi next deseribed, eonsidering it to be a fertile rond of that speeies; but although the venation in the only Bournemouth speeimen is so indistinet that I am not inclined to attach too much importanee to it, yet it hardly seems to justify the union. Pending the discovery of better speeimens, I think they must be considered distinct.

The portion of a fertile frond figured is unique, and was obtained at Bournemouth, together with a magnifieent series of dicotyledonous leaves of large size and palms, from one of the lower beds under the Coast-Guard Station, and therefore may be presumed from its surroundings to have had a shady forest labitat, and to have required a high temperature.

1 Saporta has pointed out that the venation is not very dissimilar to that of the dicotyledonous genus Andromeda, sub-genus Leucothöe.

2 'Flor. tert. der Schweitz.,' pl, vi, fig. 2, pl. cxliii, figs. 2-5.

3 Ett., 'Monte Promina,' pl. ii, figs. 1-4; Heer, loc. cit., pl. cxliv, figs. $1-3$.

4 Ung., 'Chlor. Prol.,' pl. xxxvi, IIeer, loc. cit., pls. vii, viiii. 
Phegopteris Bunburit, Heer. Plates V and X.

Lastrea Bunburit, Heer. Flora of Bovey Tracey, p. 28, pl. xii, fig. 1 b.

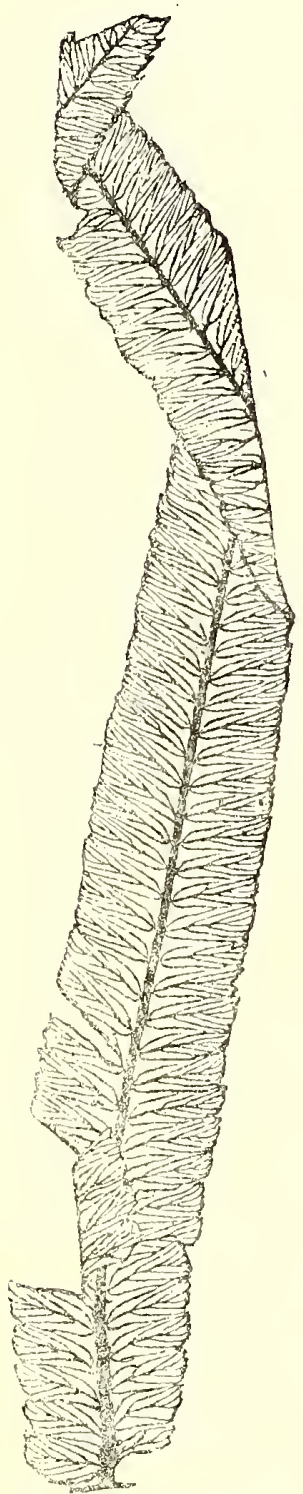

FIG. 15.-Phegopteris cuspidata.

Ph. fronde pinnata, pinnis breve petiolatis, lanceolatis, basi acutis, apicem versus angustatis, serratis, margine arguta; nervatione Goniopteridis Aspidii; nervo primario prominente, recto; nervis secundariis sub angulis $50-60^{\circ}$ orientibus, tenuibus, flexuosis, pinnatis; nervis tertiariis utrinque $2-4$, sub angulis acutis egredientibus, flexuosis curvatisque; radiis perviis.

Middle Bagshot, Bournemouth.

To Heer we are indebted for pointing out the identity of the Bournemouth form with that of Bovey Tracey.

In this Fern the fronds wcre pinnatc, the pinnæ usually rounded at the base and probably acuminate at the apex, and with lightly toothed margin. The pinne are widc apart towards the base of the frond and confluent towards the apex. The venation is of the type of Goniopteris Aspidii. All the ternary veins anastomose among themselves, and the venulcs proceeding from them are cxcurrent. The midrib is not thick, yct sevcral times more prominent than the secondary veins, which are themselves slender, sinuous, and shortly forked at the extremities. The ternary veins are fewer, only two on each side, they part at a less acute angle than the secondary ones, and form a sharp curve, which unites them with the next above of the same order. It rather resembles somc existing species of Asplenium, sub-genus Diplazium, chiefly $A$. expansum and A. Ottonis of Tropical America. It agrees closely in its characters with $P$. Eningensis, Heer, ${ }^{1}$ which differs from ours only in the stipitate pinnæ, rather closer secondary veins, and in the possession of three or four ternary veins on each side of the secondary. Stur sees a resemblance rather to Osmunda, as O. Claytoniana and O. cinnamomea.

The specimens were found in the fourth bed of the series, under elsewhere been met with, except at Bovey Tracey, where it is also extremely rare. It appears to have been a slender, graceful plant, growing under the shade of the trees with whose leaves it is found associated. That figured in Plate $\mathrm{V}$ is evidently a young, perhaps sterile plant. In Plate $\mathrm{X}$ is shown a perfect pinna.

1 Loc. cit. p. 32, Pl. VI, fig. 3. 
THE

\section{PALAONTOGRAPHICAL SOCIETY.}

INSTITUTED MDCCCXLVII.

VOLUME FOR 1880.

L O N D O N :

MDCCCLXXX. 


\title{
A MONOGRAPH
}

OF THE

\section{BRITISH EOCENE FLORA.}

BY

JOHN STARKJE GARDNER, F.G.S., M.G.S. France, \&c., $\triangle N D$

CONstantin Baron etTingshaUsen, Ph.D.,

PROFESSOR OF BOTANY IN THE UNIVERSITY OF GRATZ, ETC, ETC.

\author{
PART II. \\ FILICES. \\ Pages 39-58; Puates VI-XI.
}

LONDON :

PRINTED FOR THE PALAONTOGRAPHICAL SOCIETY. 1880. 
PRINTED BY

J. E. ADLARD, BARTHOLOMEW CLOSE. 
Some difference is apparent between the angles of the venation of the young pinnæ attached to the plant and those drawn on Pl. X, figs. 9, 10, which are more acute.

The original specimen, which should be preserved in the Jermyn Street Museum, is not now to be found there; and our identification rests, therefore, partly with Heer, who states that they are the same.

It would be better, perhaps, that the species should be described under the name of Goniopteris than under that of Phegopteris, as at page 38.

\section{Goniopteris stikiaca (Unger).}

Polypodites stiriacus, Unger. Chloris Protogrea, p. 121, pl. xxxvi. 1847.

Lastrea strriaca, Heer. Flor. Tert. Helv., vol. i, p. 31, pl. vi and vii; vol. iii, p. 151, pl. cxliii. 1859.

- helvetica, Heer. Ibid., p. 33, pl. vi, fig. 2 ; vol. iii, p. 151, pl. cxliii, figs. $2-5 . \quad 1859$.

Goniopteris strriaca, $A$. Braun. Zeitschrift Geolog. Gesellsch., vol. iv, p. 556. 1852. - - Schimper. Pal. Végétale, vol. i, p. 547. 1869.

Lastrea stiriaca, Heer. Flora of Bovey, p. 28, pl. v, figs. 12-15. 1861.

- - Gaudinet Strozzi. Contributions à la Flore Foss. Italienne, vol. ii, p. 32, pl. i, fig. 2. 1859 .

Phegopteris stiriaca, Ettingsh. Flora of Bilin, p. 16, pl. ii, f. 16-18. 1866.

G. fronde pinnata, pinnis linearibus, pralongis, inferioribus grosse crenatis serratisve, superioribus argute serratis vel serrulatis; nervatione Goniopteridis Aspidii, nervo primario valido prominente, recto, nervis secundariis sub angulis 50-65 orientibus, tenuibus, subrectis vel paullo arcuatis, nervis tertiariis in pinnis inferioribus plerumque $6-\pi$, in pinnis superioribus plerumque 4-5, curvatis, subparalle"lis, angulo acuto egredientibus. Soris rotundatis biseriatis.

Middle Bagshot, Bovey Tracey.

This Fern has not, we believe, been met with in England elsewhere than at Bovey Tracey, where it was formerly found in abundance. The pinnæ are usually attached to the rachis, and the sori are frequently preserved. The stems and circinate vernation placed with Pecopteris lignitum by Heer ${ }^{1}$ belong, in all probability, to this species. ${ }^{2}$

We have no hesitation in uniting Lastraa helvetica, Heer, with the present species. The former was first founded upon most imperfect fragments, and separated upon the supposition that it was more closely and sharply serrated, and possessed fewer ternary veins. The much more perfect specimen figured in the third volume of the 'Flor. Tert.

1 'Flora of Bovey,' p. 31.

2 See description of Osmunda lignitum, p. 50. 
Helvet.' shows that the separation cannot be maintained; for in the drawings there are in places seven veins in L. helvetica to five in L. stiriaca; while comparisons of the tracings of Heer's figures, ${ }^{1}$ here reproduced, show that $L$. stiriaca is really the more strongly toothed. It is impossible, in fact, to compare the figure of $L$. stiriaca, vol. i, pl. viii, with that of $L$. lelvetica, vol. iii. pl. cxliii, fig. 2, without recognising that the latter is the upper part of the frond of the former. The species was founded upon

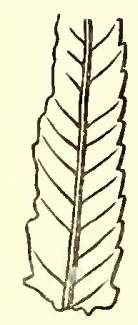

F1g. 16.-L, helvetica. 'Flor. Tert. Helv.,' vol. iii, pl. cxliii, fig. 2 (part).

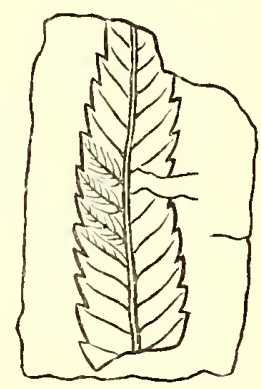

FIg. 17.-L. stiriaca. Ibid., vol, i, pl. viii, fig. 4.

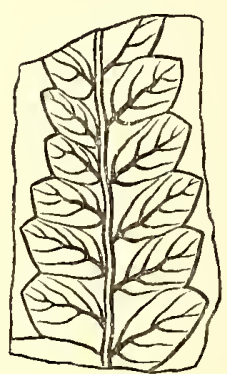

FIG. 18.-G. stiriaca (?). 'Fl. foss. Aret.,' pl. xlv, fig. 7 .

insufficient material, and should have been annulled when the more perfect specimens were figured. Specimens of $L$. dalmatica which we have received present in like manner no distinguishing specific characters, and should not remain separated.

In the 'Flora Fossilis Arctica,' p. 87, pl. xlv, fig. 7, we find a portion of a pinna figured under this name from Atanekerdluk, in Greenland. It possesses, however, according to Heer's description, only three ternary veins on each side of the pinnule; while in the description of the Swiss form six to seven were essential to the species, and

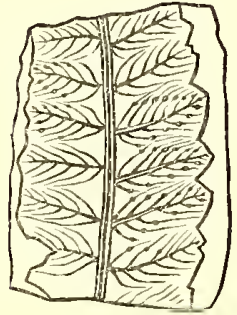

Fig. 19.-G. stiriaca. 'Flora of Bovey,' pl. v, fig. 14 (part).

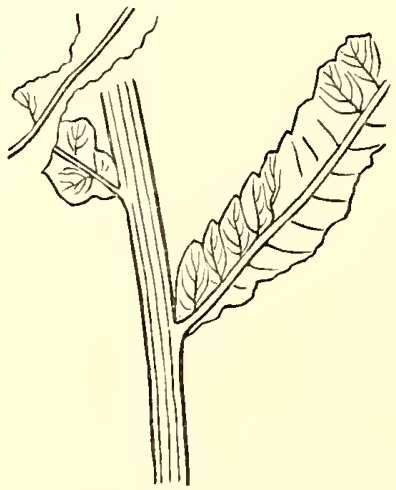

FIt. 20.-G. stiriaca. Ibid., fig. 13.

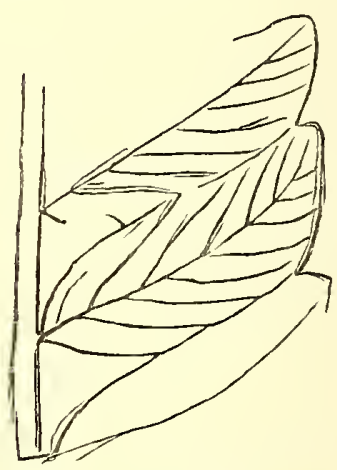

Fic. 21.-G. stiriaca. Enlarged by Mr. Fitch.

specimens possessing fewer are separated. He therefore seems to modify his specific characters to include it, and in modifying them thus, leaves them sufficiently open to

I Figure 16 shows the strongest denticulation present in the drawing of the fine specimen of $L$. helvetica in the third volume. 
admit several other supposed species. It appears from the figure that the pinna is more tapering, and therefore shorter, than those of $G$. stiriaca, and all the veins more sinuous. 'I'he indistinct specimen from Cape Lyell has the exact outline of this species.

G. stiriaca is supposed by Unger and Heer to resemble G. prolifera" "of tropical America,"' which Fern, however, it is well known, is a native of all the tropics except that one. The venation is not uncommon among Ferns, and is met with in Acrostichum and Neplerodium, as well as in Goniopteris, but the arrangement of the sori is more characteristic of the latter. In the fossil state it has been found in France, Germany, Italy, \&c., and seems to characterise principally the Middle and Upper Eocenes, and Oligocenc.

It appears to have been of much larger growth than G. Bunburii, and possessed more numerous and simply curved, instead of sinuous or angulated, veins. The original specimens are too indistinct to be satisfactorily refigured, and we have, therefore, reproduced fig. 19 and part of fig. 20 from pl. v, 'Flora of Bovey,' and an unpublished enlargement (fig. 21) by Mr. Fitch, of Kew, who has placed his original sketches for that work at our disposal.

Woodwardia? venosa, Ett. and Gard. Plate X, fig. 5, 5 a.

$W$. fronde pinnata, lacinis anguste lanceolatis, margine integerrimis; nervatione Dictyopteridis simplicis exappendiculate; nervo primario recto, prominente, nervis secundariis brevissimis tenuissimis angulo acuto egredientibus; maculis Dictyopteridis pluriseriatis, incqualibus.

Middle Bagshot, Bournemouth.

Although but one small and not very distinct fragment has been net with, the character of the venation is very apparent. The frond may have either been simply pinnate or bipinnate. There are a number of species of Pteris, as P.patens, P. decurrens, $P$. denticulata, $P$. Woodwardioides, \&c., with anastomosing venation and closely similar; we cannot, therefore, be certain that it is really a $W o o d w a r d i a$.

We have, however, placed it in that genus, because a very beautiful and undoubted species of Woodwardia has been met with in the Eocene of Monte Promina, \&c., and the Aquitanian stage of Switzerland. This form, $W$. Roessneriana, Unger, resembles $W$. radicans, and differs from ours in the possession of a row of free veins between the areolations and the margin. Our species would fall into the group of Lorinseria, Presl, of which $W$. areolata, a native of the United States, from Massachusetts to Elorida, is the best known, and, with one exception, the only existing type.

1 Ett., 'Farnkräuter,' pl. cix and cx.

2 'Flora of Bovey,' p. 28. 
Adiantum apalophyllum, Saporta. Plate X, fig. 1, $1 a$.

Adiantum apalophylum, Saporta. Flora of Sézanne, Mem. Soc. Géol. France, t. viii, p. 313, pl. ii, fig. 1. $1865-1868$.

A. pinnulis obovatis subtrapeziformibus, margine superiore sinuatis, nervatione Cyclopteridis simplicis aqualis; nervis primariis tenuissimis aqualibus dichotomis, soris apicalibus subconfluentibus.

Middle Bagshot, Bournemouth.

Small Adiantoid pinnæ had been met with among the interlaced fronds and stems of Gleichenia at Bournemouth (see p. 44), to which we considered they might have belonged, but, as similar pinnæ have since been found unassociated with Gleichenia and preserving distinct remains of sori, there is no longer any doubt that a species of Maidenhair, not much larger than Adiantum capillus-Veneris, formed part of our Middle-Eocene flora. As we see no reason to consider them distinct specifically from those found by Count Saporta at Sézanne, which only seem to differ in the absence of sori, we have placed them, with his concurrence, in that species. The segments seem to be dimidiate, as the line of fruit is only present on one side. This species differs strikingly from the group of $A$. capillus-Veneris in the linear, instead of obversely reniform, arrangement of the sori.

Detached segments are occasionally met with among dicotyledonous leaves in beds west of Bournemouth Pier.

Hewardin regia, Ett. and Gard. Plate II, fig. 5 ; Plate VII, fig. 2 ; Plate X, fig. 6 ; and Plate XI.

II. fronde membranacea simplici irregulariter inciso-lobata, subrotunda, longe petiolata, basi subtruncata, lobis lanceolatis integerrimis, undulatis vel sublobatis, margine soriferis, soris confluentibus; nervatione Dictyopteridis simplicis, nervis tenuissimis, maculis angustis lanceolatis.

Middle Bagshot, Bournemouth.

The palmate form, rectangular base, and long stipes show the specimen figured (Pl. XI, fig. 1) to have been an entire frond, and not a large terminal pinna. So much of the frond is preserved that little is left to the imagination in restoring it. It was nearly equal-sided, palmate, somewhat irregular in form, bluntly six-lobed more than half-way down, each lobe being again once subdivided. It measured six inches 
along the base, which forms almost a right angle with the stipes, and at least four inches in length. 'I'he texture is exceptionally membranous, the sori, where the lobes overlap each other in places, being distinctly traceable through it; this character removes it from Pteris, in which genus it might otherwise possibly have been placed. The stipes was glabrous, rigid, slender, and must have been at least three times longer than the portion preserved. The veins are very fine and distinct, and anastomose copiously, but become less conspicuously reticulated towards the margin, as seen in the enlargements, Pl. X, fig. $6 a$; Pl. XI, fig. 4 . The sori form long linear patches upon both edges, but do not extend to the extremities of the lobes. The specimen, Pl. II, fig. 5, is probably a small barren frond of the same species. Only the outline is preserved, which is suborbicular, with margin entire.

The slender stipes, membranous texture, and marginal sori are characters only combined in Adiantum and Lindsaya. In the latter genus L. sagittata possesses simple fronds and is not very inferior in size; but it is in the section of Adiantum with anastomosing veins, Hewardia of $\mathbf{J}$. Smith, that we find the nearest resemblance to it. $I$. Wilsoni, altlıough not possessing perfectly simple fronds, sometimes has its pinnæ almost all united in a single trilobed terminal pinna, approaching the fossil species in dimensions. Even the nearest living species, however, differ very widely from it, and it thus appears to be one of the few Tertiary Ferns that have become completely extinct. We are not acquainted with any fossil species with which to compare it.

We had frequently noticed fragments of a very membranous Fern with anastomosing venation, and two of these had been figured without any clue as to the form of the leaf, before the magnificent specimen on Pl. XI had come to light. Our attention was called to it by a lady, who found it in a small concretion of white clay near the base of the black clays, in the leaf-beds nearest to, and on the west side of Bournemouth Pier. The other fragments were found in the same beds.

(F) Gleicheniacer.

Genus.-Gheichenia.

(Sub-genus.-Mertensia.)

Gleichenia Hantonensis (Wanklyn). Plate VI and Plate X., figs. 2, 3, 4.

Mertenstes Hantonensis and M. crenata, Wanklyn. Annals and Magazine of Natural History, vol. iii, pl. i. 1869.

G. fronde gracili stipitata dichotoma; stipite scandente; cirrlis abbreviatis uncinatis; 
rachi tenui; pinnis oblongis; pinnulis approximatis patentibus, linearibus vel lanceolatooblongis, margine integerrimis vel crenatis; apice obtusis; nervatione Pecopteridis vera; nervo primario e rachi angulo subacuto, rarius recto exeunte, tenui, plus minusve flexuoso; nervis sccundariis cum primario angulos acutos formantibus, abbreviatis, catadromis, furcatis, rarius simplicibus; nervis tertiariis catadromis, arcuatis, simplicibus, rarius furcatis, infmio lateris exterioris receptaculum punctiforme emittente. Soris singularibus vel duobus rotundis, lobatis.

\section{Middle Bagshot, Bournemonth.}

The stipes and rachis are slender, and are always found associated with the remains of, and sometimes attached to the pinnules The repeatedly dichotomosing character of the stem is well seen in the specimen, Pl. VI, fig. 8, in which is also shown one of the young buds produced at the forking of the larger stipes. The stipites were furnished with short, hook-like tendrils. Figs. 9 and 10 show these tendrils with remains of the rachis, and fig. 11 with the attachment to the stipes only. On this piece and at fig. 8 are spirally rolled buds. The relative position of the tendrils and pinnæ is shown on $\mathrm{Pl}$. X, fig. 2 . The remains of pinnæ, represented in Pl. VI, figs. 1, 2, 3, and 7, show them to have been of an elongated, almost lanceolate shape, bearing linear or lanceolate pinnules of unequal length. These are closely set, with crenate or entire margin and rounded apex. The venation is that of Pecopteris vera. The midribs of the pinnules are sinuous and relatively slender; they leave the rachis, which is itself slightly flexuous, at angles of $65^{\circ}$ to $80^{\circ}$, rarely either more acute or obtuse. The secondary veins leave the midrib in catadromous order at the same angles as those formed by pinna and rachis, and are mostly forked, rarely simple. The ternary veins are also catadromous and mostly simple. The sori occur on one or both of the exterior venules of each group of veins. The sporangia were deciduous, and arranged round a small, oval, punctiform receptacle. There are visible six to eight impressions to each cluster, but only the bases of these are seen in places where the leaf has chipped off.

The fossil form is distinguished from all existing Gleichenice by the possession of tendrils or hooks, indicating a more pronounced creeping or climbing habit. With this exception, however, it bears a close resemblance to two recent species, forming sections of the sub-genus Mertensia, G. pectinata and G. dichotoma. The size and form of the pinnæ, the branched and zigzag stipes, the buds occurring in the forks, the venation, and the sori, are all similar. The resemblance is considerably heightened by the very unequal lengths of the pinnules, even when side by side, and by the fact that only those which are much longer than the rest are regularly crenated, as if the crenations were an expression of luxuriant growth. Adiantoid bracts are sometimes developed at the forkings, and these, being found associated with the fossil Gleichenia, had been thought to indicate the presence of Adiantum.

G. pectinata, which it the more particularly resembles, is a native of tropical South 
America, where it is common ; and G. dichotoma, according to Hooker, is of "tropical and subtropical regions, almost universal, in the New and in the Old Worlds, Pacific Islands, and as far north as Japan." A note by S. Hayes, in the British Muscum Herbariun, informs us that the former grows in extensive patches along the line of the Panama Railway.

The genus Gleichenia appears to have reached its maximum development in Europe in Pre-eocene or so-called Cretaceous times, and then to have died out or migrated, since no species have been met with in the Miocene. Saporta has found similar fragments in the gypsum of Aix, in Provence. Fragments are also met witl at Aix-la-Chapelle, which closely resemble it, but are stated by De Bey, after comparing specimens, to be all more or less distinct.

The distribution of this Fern in England is almost limited to a thin band, only a few inches thick, in the leaf-patch under the Highcliff Mansious at Bonrnemouth. In this layer it was abundant, and numerous specimens were obtained by residents, in some of whose collections they are still preserved. It was only after an interval of many years that some small fragments were found last autumn, the result of extended digging in a neighbouring patch. Its restricted distribution here should be taken into account in generalising on the absence of Gleichenia in the Miocene of Europe.

The position in which the remains are found, overlying a marly bed, penetrated everywhere by its rootlets, secms to imply that it flourished in a considerable patch in a wet clayey hollow.

Mr. Wanklyn kindly lent the specimens figs. 1, 3, 4, 6, Pl. VI; Mr. Pender figs. 2 and 5 ; and the Woodwardian Museum figs. 2, 3, 4, Pl. X.

Anemia subcretacea (Saporta). Plates VIII and IX.

Asplenium subcretaceum, Saporta. Flor. Foss. Sézanne, Mém. Soc. Géol. France, 3e sér., vol. viii, p. 315, pl. xxiii, fig. 4. 1868.

Gymogramma Haydenit, Lesquereux. U. S. Annual Report, 1871, p. 295 and Tertiary Flora, U. S. Geol. Survey of the Territories, vol. vii, p. 59, pl. v, figs. $1-3$. 1878.

A. stipite dichotoma, fronde bi-tripinnata, pinnis ovato-oblongis, pinnulis adnatosessilibus, subdecurrentibus lanceolatis vel lanceolato-linearibus, acuminatis, grosse dentatis vel inciso-lobatis, lobis acutis integerrimis vel crenulatis; loborum nervatione more Cyclopteridis simplicis aqualis, nervis tenuissimis valde congestis, mediano vix prominente.

Middle Bagshot, Bournemouth.

The materials for the determination and description of this Fern are abundant and 
exceptionally well preserved. Pl. IX, fig. 2, represents an almost perfect frond (unfortunately reduced in the engraving to one fourth the natural size), in which there is a double forking of the stipes and a tripinnate limb. The pinnæ are ovate in general outline, with sessile pinnules, almost decurrent at their base, as in Pl. VIII, fig. 1, or more rarely, and in the lower part of the pinnæ only, shortly stipitate (Pl. IX, fig. 2). The pimnules vary from broadly to linear lanceolate, and are very acuminate at the apex. The margins are coarsely toothed, laciniate-dentate to lobed, the lobes being acute or crenulate. The venation, magnified on Pl. VIII, figs. 3 and 4, is of the type of Cyclopteris simplex aqualis. There is either no midrib, as in the fig. 4 referred to, or it is faintly visible, as in fig. 3, and the veins are very slender and close together. No traces of fertile pinnæ have hitherto been met with.

The repeated forkings of the stipes and the type of venation point more to the genus Anemia than to Asplenium, as dichotomy is characteristic of the Schizceacea, and similar forked branching occurs in Anemia, either in the stipes of the sterile fronds only, or in both the fertile and sterile fronds.

Saporta and Heer do not agree in our determination, and the former has kindly stated at some length his reasons for differing: they are, that no known living Anemia has so lanceolated and attenuated a form, nor so coriaceous a texture; and that each segment, whether entire or subdivided, is attached directly to the rachis as a pinnule or pinna, and is never either decurrent or confluent. Anemia, he thinks, is adiantoid in growth, and has nothing in common with this Fern. On the other hand, he felt, when he described it from Sézanne, extremely doubtful whether it should be placed with Asplenium; and, these doubts being now further confirmed, he has suggested ${ }^{1}$ that, since it appears to be an extinct form with doubtful affinities, a new genus, perhaps allied to Todea through T. barbara, should be formed to receive it.

Dr. Stur, from an exanination of the plates and a small specimen which I forwarded to him, believed it to be an Osmunda. We cannot find, however, that any existing Osmunda more closely resembles it than $O$. regalis, and this seems so unlike in general growth that the data for placing it in that genus appear to us insufficient. Neither are we able to consider it an Asplenium; for, although many species of that genus resemble it somewhat in their general free growth, cutting, and venation, yet no vestiges of the sori, so abundant and persistent on the fronds of Asplenium, have ever been found in any locality upon any of the great number of specimens examined. It seems almost certain that the fertile pinnæ were separate ; and, as we have seen in the similar cases of Chrysodium and Osmunda, therefore rarely, if ever, preserved. Notwithstanding that it does not agree very closely with any existing species of Anemia, the general form and dichotony of the frond, the venation, the length and strength of the stipes, the separation of the fertile and barren pinnæ, have, after much consideration, induced us to place it in the genus Anemia.

In addition to the genera mentioned, it is also not unlike Thyrsopteris and some 
Davallia, but no known Fern resembles it so elosely as Anemia adiantifolia, ${ }^{1} \mathrm{Sw}$. , an inhabitant of Cuba, Bahamas, Florida, and Mexieo to Bahia.

Saporta has kindly eompared specimens from Bournemouth with those of Sézanne, and writes respeeting them, "Je n'lésite pas à déelarer qu'il s'agit d'une seule et même espèce." Lesquereux, to whom we are inuch indebted, has also eompared Bournemouth specimens with those from the Eocene of North Ameriea, and has written, "I do not see any difference whatever."

Asplenium Forsteri, Deb. and Ett., described in the "Urweltliehe Acrobryen des Kreidegebirges von Aachen,' pl. ii, figs. 4, 7, 11, is also elosely related to, if not identical with, $A$. subcretacea. De Bey sees in them a close resemblanee, but not identity. The speeimens figured by Heer in the 'Kreide-Fl. der Aret.-Zone,' p. 93, pl. xxvi, fig. 1, as A. Forsteri, seem to belong to quite a different speeies, and Dr. De Bey writes that this and other identifieations were made without any eomparison with his speeimens.

This Fern is found more espeeially to the east of Bournemouth Pier, and appears to have attained its greatest luxuriance when growing with Aroïds and Conifers. It decreases in size and abundanee in the beds westward, towards Poole Harbour, and at Branksea small pinnæ only are met with, such as are drawn on Pl. IX, figs. 3 and 5. The speeimen, pl. vi, fig. 6, 'Lignites of Bovey Tracey,' from Bovey, may belong to this species. Heer is eonfident that he has seen it from Alum Bay, but it may possibly have been erroneously labelled.

A fragment of this Fern, probably the one just alluded to, was named Asplenium Martinsi by Heer, but not figured, and has been referred to in several subsequent works.

(G) Schizaacea.

Lygodium Kaulfussi, Ileer. Plate VII, figs. 1, 3-8; Plate X, fig. 11.

Lygodium Kaulfussi, Heer. Flora of Skopau, Beiträge zur näher Kenntniss d. SachsThüring. Braunkohle, p. 409, pl. viii, fig. 21 ; pl. ix, fig. 1,1861 .

- NEURopteroides, Lesquereux. Annual Report U.S. Survey, 1870, p. 384; 1871, p. 284. Tertiary Flora, U.S. Survey of the Territories, vol. vii, p. 61 , 1878, pl. v, figs. 4-7; pl. vi, fig. 1.

Anemia Kaulfussi, Heer; Crié. L'ouest de la France à l'époque tertiaire, p. 22, pl. $\mathrm{A}$, fig. 3,1878 .

1 Ett., 'Farnkräuter,' pl. clxxiii, figs. 7, 8. 
L. fronde fertili superne simpliciter, inferne bi-vel ternato-pinnata, pinnis simplicibus vel bi-tripartitis, laciniis integris, dentatis, fructiferis spicas lineari-oblongas compressas obtusiusculas formans; fronde sterili inaqualiter bi-tri-quadri-partita vel simplice, undulata; lobis inaquilongis, sub angulis acutis, variis divergentibus, e basi plus minusve dilatata, elongato-lanceolatis, apice obtusis; nervatione Cyclopteridis composita, nervis primariis inaquilongis subflexuosis; nervis secundariis densis, sub angulis acutissimis orientibus, prominentibus tridichotomis.

Middle Bagshot, Bournemouth.

The pinnæ in this species, as in most Lygodia, are variable, and may be entire when little developed or cleft palmately into two, three, or four divisions. All these forms are represented on PI. VII, and might have occurred on the same plant. The lobes are usually unequal, and diverge from each other at angles of from $30^{\circ}$ to $60^{\circ}$. They are narrow, lanceolate, sometimes very elongate, generally widened at the base, where they are confluent, undulate, more or less acuminate, but sometimes obtuse at the terminations. The venation, enlarged in fig. 6 , is that of Cyclopteris composita. The primary veins are divergent and curved from the base, sinuous, attenuated upwards, excurrent or lost in the lamina (fig. 7). The secondary veins are close together, and given off at acute angles of from $10^{\circ}$ to $30^{\circ}$, thrice forked, and so sharply defined throughout their whole course that their ramifications are discernible without the aid of a lens. The lobes of the fertile pinnæ are petiolated (PI. X, fig. 11); in the upper part solitary or undivided, but in the lower part two or three occur together or are twice or thrice divided. The pinnules are linear, elongated, rather obtuse, and finely toothed on the margin, and the rachides were not winged. A small fragment was figured by Heer from the Eocene beds of Skopau. His enlargement is in form and venation identical with ours, and they caunot be specifically separated, as was indeed first pointed out by Heer ${ }^{1}$ himself. A comparison, by Lesquereux, of actual specimens from Bournemouth has shown, as appeared evident from the plates and description, that $L$. neuropteroides and the English species were one. Lesquereux says ${ }^{2}$ that "it is positively identical." Dr. Crié also has found it in the Eocene "Grès de la Sarthe." Other allied species, L. parvifolium and L. exquisitum, have been found at Aix in Provence, and Count Saporta informs us that the fertile fronds in these are identical with the British form. Since pinnæ are comparatively rare in all these widely separated localities we may infer that Lygodium had a still greater geographical range in Eocene times.

The two fossils described by Watelet as Lygodium, from the Paris Basin, belong to one species, and this bears little resemblance to any belonging to that genus.

L. Kaulfussi appears nearly allied to the form described as Miocene. Heer, in his 'Tertiärflora der Schweiz,' vol. i, pp. 41-43, distinguishes five species; but, from the figures, the propriety of giving them specific rank seems doubtful, especially in a Fern
${ }^{1}$ In letter.
${ }^{2}$ In letter. 
bearing fronds of such unequal size, and so variable that the number and angle of divergence of the lobes differ strikingly in the samc plant, while the primary veins may also be either excurrent or merged, free to the base or united. If the Swiss species are united, it is seen that the British form differs from them in having, on the average, considerably larger and longer, slightly undulating lobes. It also bore simple fronds, none of which have been met with in the latter. The lobes in the former always diverge at acute angles, whilst in the latter thcy frequently divcrge at obtuse angles. In the British form the venation is more pronounced and the veins more crowded together. Count Saporta has met with one of these, L. Gaudini, in the Upper Oligocenc of Cérestc, and has again found that the fertile fronds are identical with those of Bournemouth. Another very similar form has been described in De Bey and Ettingshausen's 'KreideFlora von Aachen,' from merc fragments. Lesquercux, in the 'U.S. Gcol. Survey of the Territories,' vol: vii, 1878, describes three other species, two of which, lowever, appear to us to have been founded on scarcely sufficient material.

Among recent species, L. palmatum, inlabiting Florida to Massachusets, bears the closest resemblance to $L$. Kaulfussi, cspecially in the form of the fertile fronds. The barrcn fronds of the fossil were much larger, and tapered to the base; yct no other existing Lygodium has such a thin and sinuous mid-rib, nor precisely the same form of fertile frond. It is remarkable, as Saporta has pointed out, ${ }^{1}$ that all the fossil Lygoclia yet described are referable to the scrction of the genus now represented by the single species L. palmatum.

L. Kaulfussi is found sparingly at Bournemonth, associated with dicotyledonous leaves of forest trees; morc rarely in company with other Fern remains. It is occasionally found in the leaf-beds under the High Cliff Hotel, but more generally in the beds at the western termination of the Bournemouth Cliffs, near Poole Harbour. The bases of the fronds are seldom preserved either in this or the Mioccne form, whilst the ends of the lobes are constantly doubled over, as if they were of soft consistence and could not withstand maceration. The fertile fronds lave not been met with associated with the barren fronds, but werc found under the Hligh Cliff Mansions by Mr. A. Baldry, junior, to whom we are indebted for the opportunity of figuring them.

(i) Osmundacea.

Osmunda lignirum, Giebel (sp.). Plate IV, figs. 1-3.

Pecopteli is lignitum, P. Crassinervis, P. Leucopetre, P. angusta, Giebel. Zeitschrift für die gesammten Naturwissenschaften, vol. $x$, pp. 303-307, pl, ii, 1857. 
Aspidium lignitum, Heer. Beitr. Sächs.-Thüring. Braunk., p. 424, pl. ix, figs. 2, 3, 1861.

DryandRa Rigida, IIeer. Ib., p. 427, pl. x, fig. 15.

Aspidium Meyeri, Ludwig (non Heer). Palæontographica, vol. viii, p. 63, pl.xii, fig. 3, 1860.

Pecopteris lignitum, Heer. Lignites of Bovey Tracey, Phil. Trans., vol. clii, p. 1047, pl. 1 , figs. 5 and 6 (not fig. 4); pl. 1ri, figs. 2-1 1 (not fig. 1), 1861.

Osmunda Grutschreiberi, Stur. Jahrbuch der k. k. Geol. Reichsanstalt, vol. xx, p. 9 , pl. ii, 1870 .

- uignitum, Heer. Ueber die Braunkohlen-Flora des Zsily-Thales, Jahrbuch der k. Ungar. Geol. Anstalt., vol. ii, p. 9, pl. 1, figs. $2,3,1872$.

O. fronde pinnata, pinnis elongato-linearibus, subcoriaceis, apicc valde attenuatis et acuminatis, basi brcviter pctiolatis, marginc profunde inciso-serratis rarius remote dcnticulatis vel basi undulatis; ncrvatione Pccopteridis vera, nervo primario basi valido prominente, subrecto, apicem versus attcnuato, indiviso; nervis secundariis numerosis, angulis acutis egrcdicntibus, plus minusve flexuosis sub apicibus loborum plcrumque furcatis; ncrvis tertiariis inferioribus furcatis sub angulis minus acutis oricntibus, rarius elongatis convergenti-arcuatis, sinum attingentibus; nervis tertiariis superioribus sub angulis acutissimis oricntibus, sape simplicibus subcurvatis flexuosisve.

Middle Bagshot, Bournemouth and Bovey Tracey.

The pinnules arc found in layers in somc of the black clay beds both east and west of the pier at Bournemouth. Whole slabs are often covered with these pinnules, which are always detached. When first found they are perfectly preserved and of a substance like coal, but on exposure to the air the leaves crack and dry up from the matrix in a few moments, and their preservation is difficult. Occasionally well-preserved pinnules are also found in the Fern-beds under the Marine Beds; elsewhere they are rare, and towards Poole I have found but a solitary fragment. T'hey occur precisely as at Bovey, and are equally associated with terminal buds of a Sequoia-like Conifer, rush-like leaves, and spines of Cactus. Stur has figured a specimen with pinnæ attached, which he has named $O$. Grutschreibcri; and he has obliged us by stating that he still considers the presence of a small basal expansion on the under-side of the pinna as of specific value. In the 'Quarterly Journal of the Geological Society,' vol. xxvi, pl. 24, p. 349, Carruthers described and figured a Fern-stcm under the name of Osmundites Dowkeri, from the Thanet Sands, which was so beautifully preserved that even the starch granules were replaced by silica and so preserved. It belonged to a larger species than O. regalis (see p. 53).

The following corrections have, in our opinion, to be made in Prof. Heer's description of Osmunda lignitum (Pecopteris, Heer), from the 'Lignites of Bovey Tracey.'

Pl. v, figs. 9, 10, 11, 'Lignites of Bovey 'Tracey,' represent circinate vernation, found as- 
sociated with abundant remains of Goniopteris stiriaca and Osmunda lignitum, and assumed by Heer to belong to the latter (op. cit., p. 31), "as being the eommonest" Fern. Nothing of this nature has been met with at Bourncmonth in beds in whieh the pinna of Osmunda are alone massed together; but at La Roehette, ${ }^{1}$ where Osmunda lignitum is absent and Goniopteris stiriaca present, identical remains are found and deseribed by Heer as portions of the latter Fern.

Pl. iv, figs. $4 a, 5,6,{ }^{2}$ represent parts of the rachis of a Fern, but there is nothing to support Prof. Heer's idea that these belong to his Pecopteris lignitum (op. cit., p. 30), as no pinnules were found attached to them. Against his views we have the fact, that the rachis of Osmunda is rarely met with in the fossil state, and is easily recognised by the deep scars left by the deciduous pinnx, also that pinnæ have never been found attaehed under the conditions in whieh the Bovey and Bournemouth speeimens are preserved; they have in faet but once been met with attached, and that under totally different conditions of preservation. ${ }^{3}$ Indeed, Prof. Heer's own figures show them in closer juxtaposition with G. stiriaca, the pinnæ of which have everywhere been met with attaehed to this kind of rachis. The enlarged fig. $6, \mathrm{pl}$. vi, is no portion of this Osmunda; but (when redueed to its natural size) is seen to be a fragment of Anemia. Compare our fig. 1, Pl. VIII.

Pl. vii, fig. 1, represents a fossil very abundant at Bovey, and of whieh speeimens are still preserved in the Museum at Jermyn Strcet. They are called by Heer "large rhizomes quite eovered with petioles" (op. cit., p. 31). We are assured, however, by Mr. Baker, of the Kew Herbarium, associated with Sir W. Hooker in his 'Synopsis Filicum,' that, in his opinion, they are not even portions of any Ferns, but apparently more like stems of the Australian Grass-trees; and in this view we entirely eoineidc. The rhizomes with cicatrieules, fig. 2, loc. cit., also do not appear to us to belong to Osmunda.

Perhaps the most remarkable, because eompletely unfounded, of the assertions which Heer made regarding this Fern is to be found at pages 25 and 33, op. cit., where, only because he fancied it might be an arboreseent Hemitelia, and the pinnæ are abundant, he states that its stems and those of Sequoia "certainly contribute the greatest amount of lignite," and "in the shade of the forest throve numerous Ferns, one species of whieh (P. lignitum) seems to have formed trees of imposing grandeur." The facts, hovever, as far as we know them, are that no vestiges of stems of Tree-ferns have ever been found at Bovey or in any British Eoeene bed; while 'Tree-ferns in their native habitats, as in Australia, seem to form a mere undergrowth to trees which are rcally of imposing grandeur.

It is strange that in each ease in whieh Heer has figured this Fern he has permitted the lithographer to make the leaf an impossible one, by colouring the outer pair of veins

1 Heer, 'Flor. Tert. Helv.', vol. i, p. 32, pl. viii, fig. 7.

2 'Lignites of Bovey Tracey.'

3 See reference to $O$. Grutschreiberi, Stur, in list of synonyms The original specimen is in the Imperial Geological Institute at Vienna. 
as if they were the margins of the leaf; for example, 'Lignites of Bovey,' pl. vi, fig. 2 , 'Flora of Skopau,' pl. ix, figs. 2 b, 2, 3; 'Flora des Zsilythales,' pl. i, figs. 2, 3; and in each case he has given it a different name. We find it described by him as Aspidium, Pecopteris (in the belief that it was a Hemitelia), Dryandra, and Osmunda. The last name did not appear in his works until two years after its true affinity was pointed out by Stur; and yet it so exactly resembles the wide-spread and well-known O. javanica that not even a good specific distinction can be pointed out. It might,

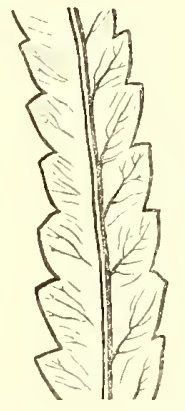

FIG. 22.-Dryandra rigida, Heer (Skopau).

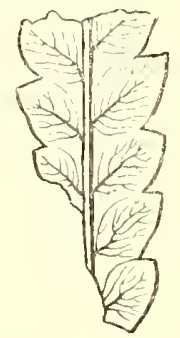

Frg. 23.-Aspidium lignitum, Heer (Skopau).

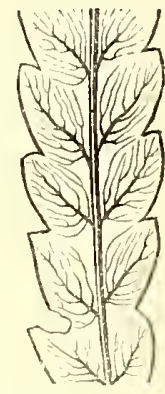

FrG. 24.-Osmunda lignitum (Bournemouth).

perhaps, have been thought that the invariable absence of any traces of spores on the pinnæ would at least have directed his attention more especially to those genera which shave fructification like Osmunda. When determining the Bovey plants Prof. Heer "sought in vain for sori amongst many hundreds of pinnules" and hesitated to name it Hemitelia, "till the fruits are found, which certainly will be soon" (p. 31).

In the 'Flora Fossilis Arctica' Heer compares a fragment named by him Pecopteris Torellii with this Fern; but the two do not at all resemble each other.

This fossil Osmunda appears to have been simply pinnate, the barren pinnæ cuneate at the base, slightly stalked, with sharply-toothed margin, and of almost coriaceous texture.

It has been frequently described, for it is met with in many localities of France and Germany, from the Tongrian and Aquitanian stages. It was not a Miocene Fern in Europe, so far as we know at present, but was essentially characteristic of the Middle Eocene and Oligocene. Notwithstanding its great abundance, fertile pinnæ have not been remarked, and only in one instance ( $O$. Grutschreiberi) have the pinnæ been found attached to the rachis.

A separate specific name appears almost superfluous, for the fossil species so closely resembles some of the forms of Osmunda javanica, Blume, as to be indistinguishable. In the latter the pinnæ are petiolated, and very readily become detached, leaving a pit-like scar on the stem, and this structural character, rare in Osmunda, seems to account satisfactorily for the detached state in which the fossil pinnæ have been found. The fertile pinnæ in the living plant are made up of numerous sessile clusters of too dense a nature, 
perhaps, to preserve any distinct form if fossil. O. javanica ranges from Kamschatka to Java and Ceylon, and is described by the Rev. C. P. Parish as a magnificent plant, similar to Cycas in growth. ${ }^{1}$

\section{Osmundites Dowkeri, Carruthers.}

$$
\begin{aligned}
& \text { Osmundites Dowkeri, Carruthers. Quart. Journ. Geol. Soc., vol, xxvi, p. 349, pls. } \\
& \quad \begin{array}{l}
\text { xxiv, xxv, } 1870 . \\
-\quad-\quad
\end{array}-\quad \text { Geol. Mag., vol. ix, p. 52, } 1872 .
\end{aligned}
$$

Thanet Sands, Kent.

This species is based upon a portion of a stem found at Herne Bay, and is admitted to have been derived from the Thanet Sands. The whole of the tissues are replaced by silica, so that the cells and vessels, and even the starch granules, which abound in the parenchyma of Ferns, are exquisitely preserved. The structure, minutely described by Mr. Carruthers, is seen to agree with similar portions of the stem of $O$. regalis, which are figured by him for comparison. The fossil has been a larger plant than our recent O. regalis. In discussing the paper Mr. Etheridge mentioned the discovery of fossil Fern stems of somewhat similar character at Bromsgrove.

Pteris (?) Prestwichis, Ett. and Gard. Plate X, fig. 8.

P. pinnis elongatis lanceolato-linearibus, margine integerrimis, nervatione Neuropteridis acrostichacea, nervo primario prominente, apicem versus sensim attenuato; nervis secundariis sub angulis acutis orientibus, valde approximatis, bi-vel trifurcatis, raris inter se parallelis, cum nervo primario angulum acutum formantibus.

Woolwich and Reading Beds, Counter Hill, near Lewisham.

Our illustration is copied from that given by Professor Prestwich in the 'Quart. Journ. Geol. Soc.,' vol. x, p. 156, pl. iii, fig. 6. We have not been able to ascertain that any of the original specimens are now preserved. Prestwich describes it as "one of the recent discoveries by the Rev. Mr. De la Condamine at Counter Hill. This Fern is probably an Asplenium; the leaflets occur in some numbers, and are associated with fragments of monocotyledonous leaves, . . . and one or more dicotyledonous leaves" (p. 156).

There is no particular reason to suppose it to be a Pteris; but in the absence of contradictory generic characters we have thought it convenient to consider it as belonging

1 See a sketch in the Kew Herbarium. 
to that genus, especially as it seems to differ but slightly from Pteris pennaformis, Heer, $P$. pseudopennaformis, Lesquereux, and other Eocene Ferns.

The specimens figured by Heer in the 'Flora Tert. Helvetica,' vol. i, as P. Parschlugiana, $P$. pennaformis, and $P$. Gaudini, belong, with perhaps one exception, to a single species. He only separates them on account of the occasionally twice-forking veins and the slightly-toothed margin of the latter. Both characters, however, are seen to be shared by $P$. pennaformis, the first in pl. xii, fig. $1 c$, and the second in fig. $1 b . P$. Gaudini is also identical, and the species is described merely on a rather smaller pinna. Fig. $2 a$ seems to be an entirely different form.

Pteris (:) Hookeri, Ilecr (sp).

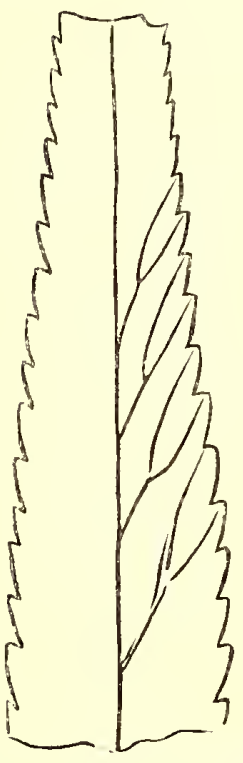

Fici.25.-P. Hookeri. Traced from Mr. Fitch's drawing.
Pecoptenis Hookert, Heer. Lignites of Bovey Tracey, p. 33, pl. vii, fig. 3, 1863.

P.pinnis clongato-lanceolatis, tenuc-serratis; nervatione Alethopteridis gcnuina, nervo primario tenui, nervis secundariis angulo acutissimo oricntibus, ramis elongatis.

Middle Bagshot, Bovey Tracey.

The drawing reproduced is from the original study by $\mathrm{Mr}$. Fitch, which is not, as stated by Heer, of the natural size, but enlarged two or three times. The specimen itself was lost before Heer described it, but Mr. Fitch's experience and reputation in delineating Ferns is so great that the accuracy of his drawing cannot be questioned. It slightly resembles portions of the Pteris Eocenica of Bournemouth; and approaches, both in its venation and serration, the apices of pinnules of a number of existing species of Pteris, as well as of other Ferns.

\section{(I) Marattiacea.}

Maratrita Hookeri, Ett. and Gard. Plate XII, figs. 1-7.

M. fronde quadri- (?) pinnatifida, submcmbranacea, rhaehide anguste alata, segmentis oblique oblongis parce dentatis; nervatione Craspedopteridis, nervo primario e rhachide angulo acuto orientc, tenui, nervis sccundariis paucis tenuissimis, vix distinetis. 
Lower Bagshot, Alum Bay.

This species appears to have been closely allied to the existing Marattia Kanlfussii, J. Smith ; and its fronds were probably, as in the recent species, tri-quadripinnatifid, and of large size. Although the pinnules figured are fragmentary and mostly detached, this condition appears to lave resulted mainly from the accidents of collection. The pinnules are lanceolate and profoundly pinnatifid. The segments are obliquely lanceolate, largest on the upper side next the rachis, and with acuminated apex; toothed towards the base of the pinnules, becoming simple and finally confluent at their apex. The rachis is slender and very distinctly winged. The texture seems to have been herbaceous to membranaceous. The primary veins of the segments are sharply defined and distinct to the apex, but the secondary veins are very indistinct, and only traceable on one specimen (figs. 4 and $4 a$ ), in which they seem to be few, simple, slightly curved, forming an obtuse angle with the mid-rib, and terminating in the marginal teeth; and on another (fig. 6, 6 a), from apparently a basal pinnule, in which they are seen to be more complex. In the existing species the synangia are sitnated on the secondary veins of the seg-

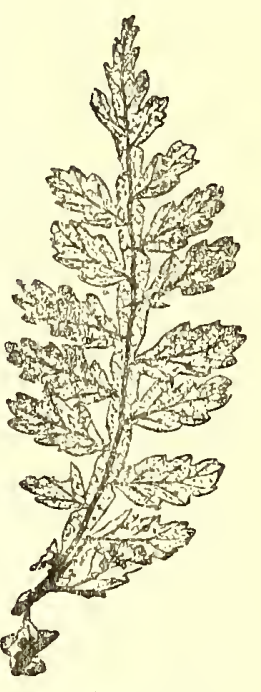

Fig. 26.-Marattia Kaulfussii. ments, not easily removed, and leave behind them the basal part of the short stalk by which they are attached. No trace of even this attachment, however, is discernible in the fossils, except in one instance where there is an appearance of the synangia themselves being preserved (fig. 6). The fragment, barely two centimètres in length (Pl. XII, fig. 7), presents greater decurrence in the segments, and might on this account have been considered separate, but that this character is seen to an even greater extent in the ends of the pinnules of $M$. Kaulfussii.

Marattia Kaulfussii is the only species belonging to the group Eupodium, separated on account of its short-stalked synangia without an involucre. Its fronds measure three to four feet in length. It inhabits the West Indies and Columbia to Ecuador and Rio Janeiro. M. Hookeri is distinguishable by its more elegant and slender pinnules, the more sharply lanceolate and less deeply toothed segments, and less amply winged rachis, resembling in these respects, very closely, the young fronds of the existing species with which it is compared.

No fossil Fern distinctly belonging to Marattia had previously been described.

M. Hookeri seems not to have been rare at Alum Bay, but it had been overlooked in collections owing to its superficial resemblance to Conifers with which it had been found associated. There is now but little hope that better specimens will be obtained from the locality.

Filices incerte SEDIS.

I. The specimen figured in Pl. II, fig. 6, presents no sufficient characters for 
determination. It is apparently an oval leaf, sessile on a stem, something like Potamogeton. The venation is "Cyclopteris," and therefore cannot be that of a Monocotyledon, and, although obscure, is seen to be converging, and the veins may have been united to the stalk. In one place, near the base, a distinct forking is seen. Heer regards it as referable to Alisma or Potamogeton.

II. A fragment of a leaf (fig. 27), from Reading was figured, together with others,

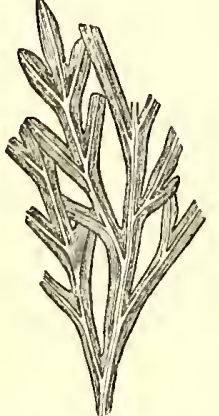

FIG. 27.-Fern leaf from Reading, after Prof. Prestwich's figure. by Professor Prestwich, in the 'Quart. Journ. Geol. Soc.,' vol. x, pl. iv, fig. 11. Sir Joseph Hooker, who examined it, remarks (op. cit., p. 166) that it resembled a fragment of. a Fern frond, "but equally well represents a portion of the pinnatifid leaf of a composite or umbelliferous plant, and may, indeed, be referred to very many other natural orders." Leaves of composite or umbellifcrous plants, however, are not met with in the Eocenes, while Ferns are seldom absent from any assemblage of their vegetable remains; since, therefore, the form closely approaches to that of some Ferns, as Asplenium dimorplum, \&c., it seems most probable that its place is among them. It bears a resemblance to forms, from the supposed Cretaceous rocks of Greenland, described by Heer as Jeanpaulia.

III. Pl. X, fig. 7, represents the only fragment of Fern yet found at Bromley. It might be placed in Aspidium or Gleichenia, and there are fossil forms figured in Heer's 'Arctic Floras' with which it could possibly be united.

IV. There are, in addition to the Ferns described above, indications of a variety of other forms from Bournemouth, which we have thought too uncertain or fragmentary to be worth including in our descriptions. Three of these appear to be Polypodia, one recalling $P$. serpens and another $P$. bifrons.

Perhaps the most striking fact brought to light during the progress of our work thus far, is the identity, or at least similarity, of the majority of our British Eocene Ferns with those of other fossil floras containing dicotyledons, already described from Europe or America. All of them are well represented elsewhere, with the exception principally of our group of Phymatodes, Hewardia, and Marattia. This, and other facts connected with them, will be best brought out by tabulating them according to Sir W. Hooker's classification (omitting, however, all those about whose determination we feel any degree of doubt), and uniting with them their fossil allies. Although each of the groups so composed only comprises forms which might apparently be united, since they seem to come within the limits of variation seen in analogous species of existing Ferns, yet it is most desirable to retain all specific names which mark constant differences. Not only may these become of the greatest value in determining the relative ages of fossil floras in the absence of stratigraphical evidence, but by a due appreciation of the slight, but progressive changes in what must, in a broad sense, be considered as the same species 
of plant, we may hope to trace its life-history. Thus, it can scarcely be doubted that we are already in possession of a series of modifications of the species of Lygodiun now represented by L. palmatum, a form so distinct at the present day that it is the only type of one section of the genus, and the history of which, traced back to pre-Eocene times, is marked by slight but frequent modifications in the form of the barren fronds, while the fertile fronds have remained almost unchanged.* On the other hand we see, for example, that hardly any modification has taken place in Chrysodiun aureum, and none is perceptible in Osmunda Javanica since Eocene times.

TABLE OF THE MORE DISTINCTIVE OF THE BRITISH EOCENE FERNS, WITH THEIR NEAREST FOSSIL AND EXISTING ALLIES, ARRANGED ACCORDING TO SIR W. HOOKER'S CLASSIFICA'TION.

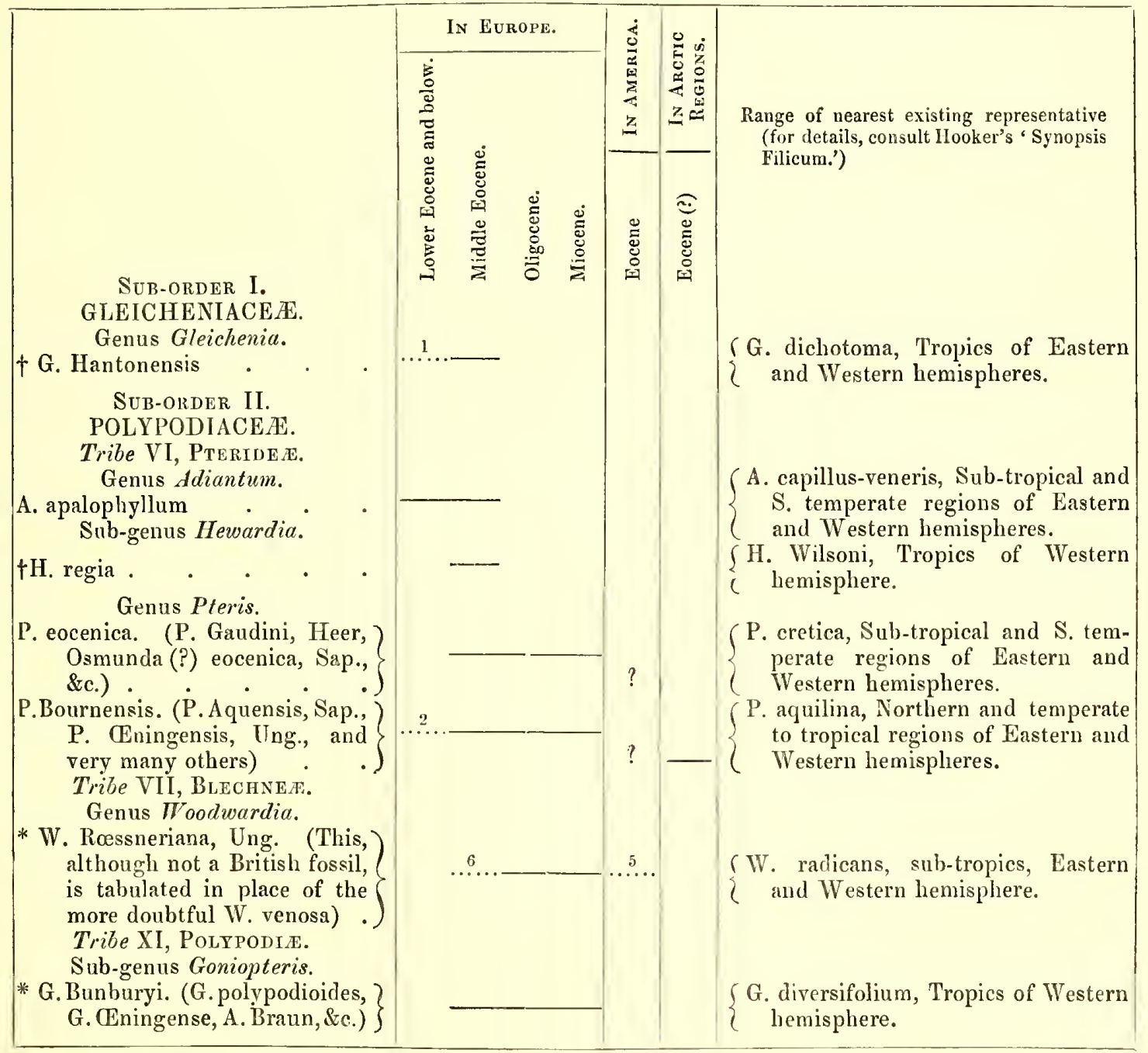

* We are indebted to Count Saporta for information concerning the fertile fronds. 


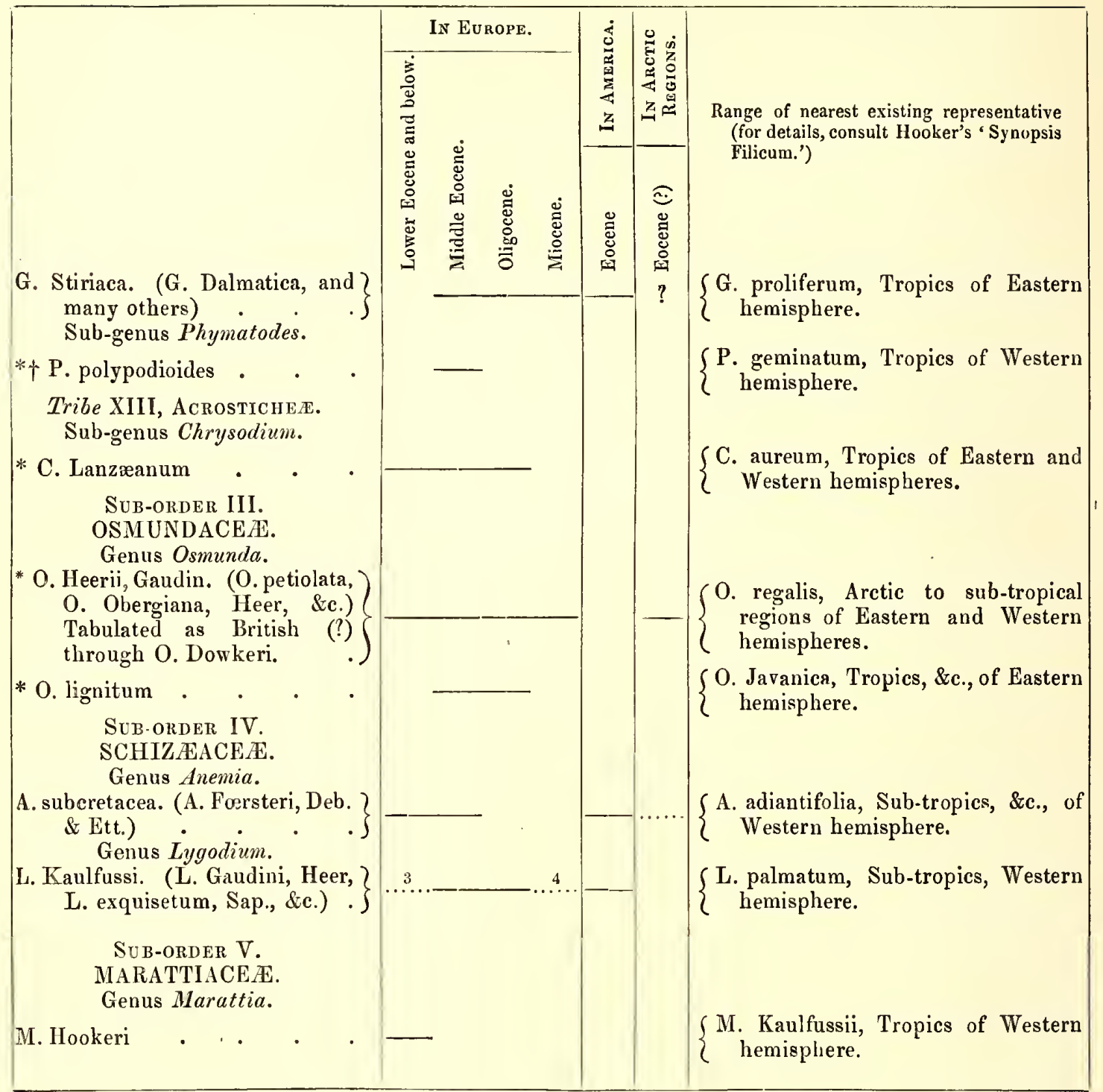

* Signifies that the form is almost specifically indistinguishable from existing species. + Indicates that the fossil species has only been met with in England. ... That the form is represented by a less closely allied species. 1, 2, 3, are Aix-la-Chapelle species. 4, L. Kargii, Heer, of Oeningen. 5, W. latiloba, Lesq. 6, W. venosa. The allied species are enclosed in ( ).

The above table comprises fifteen species, which have heen described from such exceptionally ample and well-preserved specimens that it seems unlikely that doubt can arise respecting the accuracy of their determination. The list might have been extended, yet even as it stands no striking group is omitted except the Tree-ferns of Sézanne, and it is thus remarkable that nearly all the distinctive forms and those of most value for comparison should belong to our British Eocene flora. Compared with the total number of existing Ferns they appear very few ; yet, contrasted with the present fern-flora of North America, which contains but fifty species, with that of Europe, which possesses but sixty, or still more so with that of Great Britain, which has but thirty-six, their number does not appear insıgnificant. 
The preceding table ${ }^{1}$ is full of suggestive interest and contains new evidence bearing upon questions of the highest physical importance.

In conclusion the principal types arc recapitulated, in order to include details of distribution and relationship to other recent and fossil Ferns omitted in the specific descriptions.

\section{Gleichenia Hantonensis, Wanklyn. (Page 43.)}

The only Gleichenia yet met with in the Eocene closely resembles G. dicliotoma, the sole existing representative of a well-defined subsection of the genus. The agreement between them is striking, and extends to some minute details; thus, the primary veins are grouped and divided identically, the sori are identical in form, and, like in G. dichotoma, although usually situated on the upper or left hand secondary vein only, sometimes occur on both the secondary veins. This duplication of the normal single sorus to each primary vein characterises De Bey and Ettingshausen's genus Didymosorus, a genus which can hardly now be sustained since $G$. dichotoma has sometimes more than one sorus to each primary vein. From the very fragmentary condition of the few specimens figured by De Bey and Ettingshausen, it cannot yet be said that the possession of two sori to each primary vein is a constant character. But were the fixity of this character apparent there might now be hesitation in attaching specific value to it. The stipes, rachis, and even the leaves in vernation were glabrous.

Specimens of Gleichenia dichotoma from Sydney and East Australia appear less rigid and more membranous in character than those from elsewhere, and the Eocene species

1 We have but to consider the almost complete absence of any records of other herbaceous plants, the difficulty with which mountain species, which form a large proportion of fern-floras, or species with such habits as Ophioglossum, Asplenium ruta-muraria, A. Ceterach, \&c., could find their way into these deposits, to realise that we are probably only acquainted with those ferns whose habits favoured their preservation.

But as nearly the whole of them have been found at Bournemouth, almost on one spot, and as repeated search has brought no new forms to light, there can be little doubt but that we possess a nearly complete knowledge of the Eocene lowland forest fern-flora of at least this locality, and probably no existing area would furnish a greater variety of types under similar conditions. Although, therefore, the number is small compared to otlier orders of plants, we cannot help believing the fern.flora to have been extremely rich, considering, as we have said, the complete absence of genera even as cosmopolitan as Asplenium, whose habits are less favorable to preservation.

The British and foreign Ferns provisionally placed together in this table were united, in some casea, from a comparison of illustrations and descriptions only, and the grouping is therefore to a certain extent but an indication of useful work still to be carried out. 
seems more closely to agree with them in this, as well as in the undulation and frequent crenation of the margin of the longer pinnules.

In spite of so many points of resemblance the specific difference between the fossil and its existing ally is extremely well marked. The fossil form appears to have possessed a longer and more repeatedly branching stem. In the recent form the pinnæ are dichotomous, and, as I interpret the fossil species, it also was dichotomous, for the hook or short tendril at the base of the single pinna represents the aborted second pinna converted into this singular form. This highly specialised condition may have been induced by the comparative length and weakness of the rachis, the want of rigidity in which is indicated in the fossil by the somewhat sinuous midribs of the pinnæ.

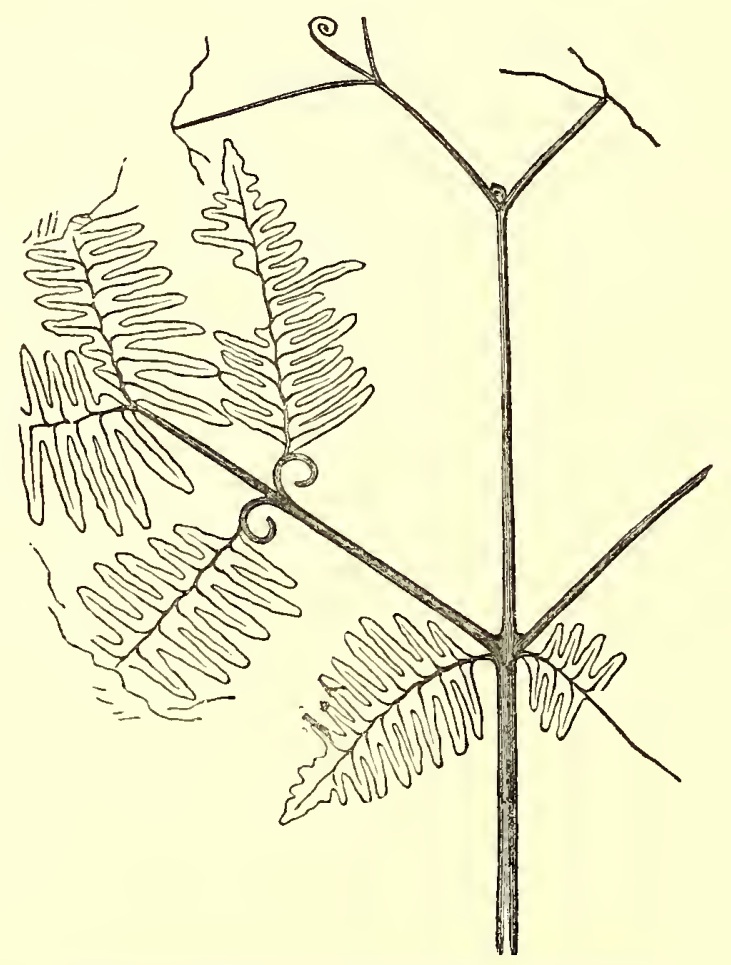

FrG. 28.-Habit of Gleichenia Hantonensis restored.

The conversion of these pinnæ into tendril-like supports appears to have been compensated by the former development of the now rudimentary buds, always present between the forking of the stem, into a third pinna or smaller pair of pinnæ. ${ }^{1}$ With the disappearance of the tendrils in the existing plant this central bud has ceased to expand, or exceptionally becomes a barren adiantoid bract. Pl. VI, fig. 3, may represent one of the simple pinnæ from the base of the forked branches, characteristic of the section of G. dichotoma. The position of these in the existing plant is shown in fig. 28.

Remains of this fern were formerly so abundant at Bournemouth that it is to be

1 The restoration shows a pair of terminal pinnæ, taken from Plate X, fig. 2. 
regretted that no collector should have secured specimens exhibiting its growth in a more satisfactory manner. Remains of forked stems, 3 to $5 \mathrm{~mm}$. in width, associated with the pinnæ, are doubtless the thicker parts of the rachis, and show that these and the fronds were of large size.

This description, although differing in some respects from the former one, is, I believe, more correct, being based upon a larger number of fragments.

G. dichotoma is almost universally distributed in Tropical and sub-Tropical regions, but varies much in habit. The characters given above and the glabrous leaves in vernation and the stipes bring the fossil more distinctly near to the Australian than to any other of the representative types of the species.

Although rare or absent in the Eocenes, Gleichenias are abundant in the supposed Neocomian and Upper Cretaceous rocks of Greenland. Heer has separated the fragments into sixteen species, although the greater part, when compared with G. glauca, ${ }^{1}$ their nearest existing representative, seem to come well within the limits of variation of that species at the present day, even if specimens from one locality only are examined. The presence of the genus in these high latitudes is repeatedly alluded to by Heer as indicating a former approach to a tropical climate in the Arctic regions. Yet Gleichenias now flourish in the rigorous climates of the Magellan and Falkland Isles, S. lat. $53^{\circ}$, which have an isotherm of $45^{\circ}$, and are also found on the mountains of Tasmania and on the Andes at an altitude of 10,000 feet, which Humboldt places at the level of gentians and near the limit of arborescent vegetation. It is instructive to notice that while the fossil Gleichenia of the Eocene of our latitude has its nearest ally in the distinctly tropical G. dichotoma, the living representative of all the Arctic forms should be the only one still ranging into the northern temperate regions in China and Japan.

\section{Adiantum apalophyllum, Saporta. (Page 42.)}

The British fossil examples are detached pinnæ of small size, like those found at Sézanne, but preserving in some instances the arrangement of the sori. They differ from the existing European species in the linear instead of obversely reniform arrangement of the sori, and in being dimidiate, yet no species bears a greater general resemblance to them than A. Capillus-Veneris. A. formosum, from the Arctic Neocomian, supposed by Heer to be an Adiantum with small simple reniform fronds, has the stem and appearance of one of the Ginkgos, which are everywhere characteristic of the secondary rocks in those regions, nor was anything advanced to support his view. No certain Adiantum is known from the Polar Tertiary flora, and but mere indications of it from the Miocenes of Europe. The Oligocene of Armissan has, however, yielded a portion of a frond with nearly fifty cuneate

1 G. longissima, Hooker, 'Synop. Filicum.' 
segments, bordered along their upper margin with sori, which Saporta sees reason to refer to Lindsaya. ${ }^{1}$

\section{Hewardia regia; Ett. \& Gard. (Page 42.)}

This is perhaps the most remarkable form obtained from Bournemouth, and is quite distinct from any other Eocene Fern. The largest specimen measures 5 inches across, and is probably an entire frond. The only existing Fern resembling it is Hewardia Wilsoni, from Guatemala, belonging to a section of Adiantum characterised by anastomosing venation. There are but four species of Hewardia known, all of them almost peculiar to the Equatorial and Central America. The fossil differs enough, however, from even its nearest known ally to entitle it to be considered an extinct type.

\section{Pteris mocmica, Ett. \& Gard. (Page 32.)}

This form, widely spread in beds of Tertiary age, in the temperate regions of Europe and America, resembles Pteris cretica and other existing allied forms of Pteris. Fossils from other localities falling into this group have received many separate names upon such characters as the toothing of the margin and the angle and forking of the veins, ${ }^{2}$ yet may possibly belong even to the same species.

$P$. eocanica is, perhaps, the best type of the species, which should, under whatever name, include all the forms with pinnæ, whether entire or toothed, which have veins running for the most part at a rather obtuse angle with the midrib, simple to twiceforked, and not too crowded together. Other distinct Tertiary species are known, such as $P$. gladifolia of Ludwig, with extremely closely-set parallel veins, resembling $P$. pellucida of the Philippines, but the group needs revision. No examples, it is important to notice, of this type seem ever to have existed in any Arctic flora, although they are so abundant everywhere in the beds approximating to the same ages in temperate zones.

1 Gervais, 'Mém. de l'Acad. de Montpellier,' vol. v, p. 311, pl. x, fig. 1.

2 In the 'Flora Tert. Helvetica' the same form appears as $P$. parschlugiana, $P$. Gaudini, and $P$. pennaformis, the first being separated on account of its occasionally twice-forked veins, notwithstanding that the figure of $P$. pennaformis has also twice-forked veins, and because its pinnæ are partially denticulated. The value of the second specific character is shown by the fact that, while in China and Japan, $P$. cretica is generally deeply toothed, it is found in many other regions with a perfectly smooth margin. $P$. Gaudini is only separated because it is somewhat smaller. There are many other forms which, judging by the published illustrations and descriptions, may possibly have to be included, such, for instance, as Osmunda eocanica. 


\section{Pteris Bournensis, Ett. \& Gard. (Page 33.)}

This is rather an unsatisfactory species, and should be included with a large number of other so-called species from the Tertiaries. These forms when united would bc an even more extensive group than the last, and, unlike it, are met with fossil in the far north. It seems to figure under at least five names in the 'Flora Helvetica,' and is almost cqually well represented in Austria and France. By omitting a trifling character, Heer unites a specimen from Atane with one of the Swiss forms. The living $P$. aquilina, to which it is allied, is found, not only in all temperate zones and in the Tropics, but, like the fossil, passes into the Arctic Circle. Owing to the variability of the pinne the living Fern also has an extensive synonomy.

\section{Woodwardia? venosa. Ett. \& Gard. (Page 41.)}

The British fossil species is founded upon a small fragment, barely sufficient to show that, if truly belonging to Woodwardia, it differs completely from the better-known fossil form and falls into the group of Lorinseria, Pres., of which $W$. areolata, Moore, a native of the United States, from Massachusetts to Florida, and $W$. Harlandii, Hk., from Honkong, are the only cxisting types. Unger's Aquitanian species, W. Rcesneriana, from Austria and Switzerland, is known from fine specimens with vcnation and sori beautifully prescrved, and, together with very similar forms from the Lignitic Eocene of America, belong to the monotypic group of Euwoodwardia. They agree almost precisely with $W$. radicans, which still inhabits Southern Europe, Northern India, Java, Japan, California, Mexico, and Guatcmala. The same species has been found in the Pliocene of Meximieux and in the Quarternary of Madeira. Woodwardites arcticus, of Heer, from Greenland, is transferred to Onoclea (page 68).

\section{Goniopteris Bunburit, Heer. (Page 38, undcr name Phegopteris.)}

This species represents a type which appeared in Europe in the Middle Eocenc, and survived until the Mioccnes, ${ }^{1}$ but has not yet been met witl in any of the Arctic or American fossil floras. It is distinguished from the next and far commoner type by its angulated and much anastomosing veins. It apparently closely approaches some of the varieties of G. diversifolium and G. tetragonum, of Brazil, but the persistent absence of sori 
renders it more probable that it may belong to Struthiopsis, a section of Onoclea, with similar venation, in which the fertile fronds are separate and of a kind not easily preserved. The venation is also met with in Acrostichum and Nephrodium, one species of the latter, $N$. amboinense, resembling the fossil almost as much as the Goniopteris mentioned.

\section{Goniopteris stiriaca, Unger. (Page 39.)}

This and a number of similar species, most of which need not have been separated, are distinguished by their pinnatifid or distinctly crenate pinnæ, and by curved, instead, as in the former species, of angular secondary veins. In the Bovey and some other instances all the secondary veins anastomose, in others fewer, or the lower pair only. The attachment of the pinnæ to the rachis and the sori to the pinna is remarkably constant, even in small fragments. In England it has only been collected at Bovey 'Tracey, but in Switzerland, Austria, Italy, France, and America, numerous specimens have been found and sometimes described as distinct species. On the other hand, it may be doubted whether the specimens from the extreme north, as Cape Lyell and Atanekerdluk, are really the same.

The venation is of a type common to many genera among Ferns, and, like that of G. Bunburii, occurs in Acrostichum and Nephrodium, but in the present case the arrangement of the sori lends support to our determination. Unger considered that it most resembled G. proliferum, but there are species which even more nearly approach it, and the form and venation recur in several genera.

9. Phymatodes polypodioides, Ett. \& Gard. (Page 29, under genus Podoloma, Ett.)

No Polypodium with reticulated venation has previously been met with fossil in such excellent preservation. It is strictly confined at Bournemouth to a local bed, in which the pinnæ abound, lying flat and in layers, having been articulated and deciduous. They so resemble dicotyledonous leaves as to have induced some scepticism with regard to their classification, but comparison with existing Ferns, especially with those indigenous to Tropical America, such as $P$. geminatum, $P$. stigmaticum, $P$. lycopodioides, and $P$. persicariafolium, places its position beyond all reasonable doubt, and also shows the genus Podoloma to be unnecessary. It appeared especially remarkable from the fact that the reticulations converge round the sori (Pl. XII, fig. 10), but an examination

1 The same species may be represented at Bournemouth by the pinna described as Phegopteris pracuspidata. 
of the upper surfaces of the fronds above the sori of $P$. geminatum and the other species named, shows that this peculiarity is shared by them in an identical manner. In texture and every other comparable character they are the same. Only slight traces of this group have been met with elsewhere. The form named Glossochlamys appears also, from more perfect specimens (Pl. XII, figs. 8, 8 a), to be an Acrosticlum, allied perhaps to A. Preslianum, Hk., A. variabile, Hk., and A. nicotianafolium, Swz.

\section{Chrysodium Lanzeanum, Visiani. (Page 26.)}

The species is one of the most distinctly characterised of all the Eocene Ferns, and so closely resembles $C$. aureum as to be indistinguishable from it, except that in luxuriant fronds from the Middle Eocene the pinnæ are sometimes more decurrent than has been observed in the living species. It has been found abundantly in the Lower, Middle, and Upper Eocenes, or Oligocene in England, and in similar beds in France and Austria. The existing species is spread over almost the whole coasts of the Tropical and subTropical World and prefers sea air. The pinnules seem to decrease in size from Lower to Upper Eocene, but no good specific distinction is apparent.

\section{Osmunda Heerir, Gaudin. (Page 53.)}

This species may be said to be almost indistinguishable from 0 . regalis. It has not been found fossil in England unless Osmundites Dowkeri, from the Thanet Sands, be its stem. It appears as early as in the supposed Neocomian Komeschichten of Greenland, as O. petiolata, and may probably be united with Ferns of even older rocks. It next occurs in the supposed Upper Cretaceous of Atanekerdluk, as O. Heerii and O.Obergiana. ${ }^{2}$ It has also been found in the Eocene Lignitic of America, the Aquitanian of Switzerland, the supposed Miocene of Manchuria and Greenland (?), and the Quartenary of Madeira.

1 The late M. Watelet's collection from the Grès du Soissonnais having come into my possession, I am able to state that Lygodium crassicostatum, Wat., and $L$. capillare, Wat., figured, Plate xiii, 'Plantes foss. du Bassin de Paris,' appear to be merely fragments of $C$. Lanzceanum. The indistinctness of the specimens, which are in a coarsely-grained matrix, and the possession of a dried frond of a Lygodium with anastomosing venation and somewhat similar outline, doubtless led to their otherwise unaccountable reference to that genus.

2 There seems a possibility, from the figures and descriptions published by Heer, that Asplenium Boreyana, A. Nordstromi, and Pecopteris Pfaffiana, may be but a smaller variety of it, since the ouly supposed marks of sori mentioned among any of the latter were found on a single small specimen, and stated to be very indistinct. 
The present range of $O$. regalis is from Sweden to Siberia, Japan, Azores, Bombay, Cochin, Hong-kong, Africa, and from Canada to Rio. Unlike O. javanica, the fronds of $O$. regalis attain their greatest luxuriance in moist, temperate regions, such as Ireland, and decrease in size towards the Tropics. Its absence from our Eoccne beds (except possibly from the 'Thanet Sands) is very significant.

\section{Osmunda lignitum, Giebel. (Page 49.)}

This is a species of somewliat limited vertical range common in the Middle Eocenes of Central Europe, Francc, and England, where specimens have been found in profusion. It is indistinguishable by any specific character from the existing $O$.javanica, and the expediency of giving it a separate name is very doubtful.

Osmunda javanica is a magnificent species inhabiting the East Coast of Asia, from Kamschatka to Java and Sumatra; more than sixty degrees. It attains in the latter countries a luxuriance unknown elsewhere, some pinnæ collected by Beccari in Sumatra measuring 9 inches in length, by $1 \frac{1}{4}$ inch broad, while the pinnæ of plants from farther north, especially from Kamschatka, do not exceed 4 inches in length, and are only $\frac{1}{4}$ of an inch broad. It is in the more average-sized pinnæ from Formosa, latitude $24^{\circ}$, that we meet with the most absolute identity, as far as the fragments admit of comparison, with our fossil form. ${ }^{1}$ If the size of the pinnæ actually decreases progressively with the isotherm, as appears to be the case in the large series at Kew, this fossil, from its identity with the existing species, may be of use in determining our Eocene temperature. It is remarkable that the most luxuriant fronds from Java and Sumatra have simple margins, while the smaller northern forms become usually morc or less deeply serrated. The greater luxuriance attained by it in southern habitats shows it to be an essentially tropical form, while as fossil it has never been found in northern latitudes : nor either recent or fossil in any part of America. It seems to be met with in Europe in Middle Eocene and Oligocene times, and no case is yet known to me of its occurrence in beds of much later date, notwithstanding that Saporta places its horizon in the Miocene.

1 The longest pinna in my collection, an imperfect one, measures nearly six inches and nine-tenths in length. 


\section{Anemia subcretacea, Saporta. (Page 45.)}

Anemia subcretacea is very abundant and well preserved, and in cne instance nearly an entire frond was obtained from Bournemouth. It seems essentially characteristic of the older Eocene, and even pre-Eocene Rocks, and has never been found in horizons higher than that of Bournemouth in Europe, and the lowest stage of the Great Lignitic in America. 'To the same group belong, without doubt, the Fern described as Asplenium Jolinstrupi and A. Dicksonianum, Heer, from the Cretaceous Komeschichten of Greenland, and Asplenium Försteri, from Aix-la-Chapelle. They possess the same strength and peculiar dichotomy in the stipes and vernation, the same graceful cutting in the leaves and easy flowing venation, the same universal absence of sori, plainly indicating that they could not belong to Asplenium. A. Nordenskiöldi and A. hyperborea may be smaller species belonging to the same genus, and Sphenopteris eocenica of Europe and America should certainly be linked with it.

These varieties might be united into at most two or three species. The larger, a singularly well-marked form, ranged from the South of France to the Arctic regions, though, perhaps, not synchronously, and first appears in the Cretaceous, and somewhat suddenly disappears in the Middle Eocene. It bears no very striking resemblance to any existing Fern, but the one most like it is Anemia adiantifolia, indigenous to America from Florida to Mexico and Bahia. The fossil form appears to have attained its greatest luxuriance in the Eocenes of temperate latitudes, and there is a marked difference in this respect between the average of our specimens and those from the Arctic regions.

\section{Lygodium Kaulfussi, Heer. (Page 47.)}

The fossil is found in Central Europe, France, England, and the United States, and is essentially a Middle Eocene Fern. A smaller and somewhat modified form seems to have preceded it in the Cretaceous rocks of Aix-la-Chapelle. L. palmatum, ${ }^{1}$ indigenous to Massachusetts and Florida, approaches it closely in some respects, but the Eocene form was very much larger in the barren pinnæ, and the fertile pinnæ were much smaller and even more deprived of parenchyma. While possessing several characters of L. palmatum, it far more resembles Tropical species, such as $L$. dichotomum in size and general mode of growth. No species of Lygodium have been met with among the Arctic fossil flora.

1 It is remarkable that all the fossil Lygodia belong to the section of L. palmatum. The barren fronds of the species found at Bournemouth are large compared to those from other Eocene, Oligocene, and Miocene localities, yet no differences are perceptible between any of them in the fertile fronds. 
The discovery, subsequent to the publication of our description, of fertile fronds of Lygodium with very short and completely separated pinnules, closely resembling in their appearance and disposition the specimen described with some doubt as Asplenites pra-allosuroides, has convinced me that this supposed species is only an example of the fertile frond of Lygodium, with exceptionally abbreviated pinnules. The thick carbonized substance and consequent indistinctness of this and of the original Asplenites allosuroides from Sotzka, is entirely in favour of this view, and both species must, I think, be referred to this species.

\section{Marattia Hookeri, Ett. \& Gard. (Page 54.)}

Marattia Ilookeri has only been detected at Alum Bay, where it is by no means rare (Pl. XII, figs, 1-6). It appears to be closely allied to M. Kaulfussii, of the West Indies, Columbia, and the Brazils; more particularly resembling it when the fronds are not fully developed. M. Kaulfussii is the only species belonging to the group Eupodium, separated on account of its shortly stalked synangia without an involucre. No fossil Marattia was known previously, and no other Fern is known from Alum Bay, unless it be Anemia subcretacea, which Heer states to have been found there. ${ }^{1}$

16. Onoclea hebraidica (Forbes). Plate XIII, figs. 5 and 6.

Filicites hebraidicus, Forbes. Quarterly Journal Geological Society, vol. vii, p. 103, pl. ii, fig. 2, 1851.

Onoclea sensibilis, L., Newberry. Ann. Lyc. Nat. Hist., N. Y., vol. ix, April, 1868. Woodwardites arcticus, Heer. Flora fossilis arctica, vol. i, p. 86, 1868.

O. fronde pinnata, pinnis oblongis vel linearibus, pinnatifidis, lobis rotundatis, denticulatis vel integerrimis; nervatione Dictyopteridis composite exappendiculata, nervo primario subrecto prominente, nervis secundariis tenuibus flexuosis, angulo acuto egredientibus; nervis tertiariis brevissimis dictyodromis, maculis Dictyopteridis 2-3 seriatis, incqualibus.

From the Ardtun Beds, Mull.

The material upon which the description of this Fern is based consists of the apex of

1 This and C. Lanzaanum are given in Baron Ettingshausen's list of the Alum Bay flora, I think in error, as neither Keeping nor myself have, after years of collecting, ever come across them, and no specimen of either Fern from that locality is now preserved in the national collections. 
a frond and numerous smaller fragments. The section Euonoclea, of the small genus Onoclea, L., with which we have identified it, is represented by a single species, $O$. sensibilis, a large herbaceous dimorphic Fern, with copiously anastomosing veins, belonging to the tribe Dicksonieæ of the sub-order Polypodiaceæ.

The pinnæ in fig. 5 are simple and not divided to the rachis, the lobes bluntly rounded and but slightly cleft, the margins undulated as in the existing fern; their full length is not preserved, the breadth is three quarters of an inch.

To judge from existing species, the frond may have been of large size, with the pinnæ simple, decurrent near the apex, and slightly stalked towards the base. The membranaceous fronds seem to have been quickly destroyed by maceration, for, with one exception (fig. 5), only fragments (fig. 6) are known. They occur in a black shaly matrix, and are therefore not easy to trace out, while the undulations of the pinnæ have become pressed into folds in places, rendering the venation confused.

The rachis is moderately thin, the midribs of the pinnæ slender, and the veinlets fine and decided. The venation of fig. 5 , accurately enlarged at $5 a$, is the less common type, and anastomoses less than is usual in the existing species. The primary veins are seen to leave the midrib at an angle of about $60^{\circ}$. The veinlets are unequal and are more numerous and important above the primary vein, or nearer the apex of the pinna than below it. The lower veinlets start from near the base of the primary vein of each group and unite with the next, forming a series of angulated areolations on each side of the midrib. Nearly all fork once, sometimes twiee, and are continuous to the margin which is slightly denticulate. Some veinlets unite with those of the same, and others with those of contiguous groups for short distances, and then again diverge, forming oblong, angulate, or ovate meshes, which vary greatly in size. In fig. $6 a$ the anastomosis is more frequent and complicated, the veinlets on the lower side of the primary vein being almost entirely absorbed in the system of meshes proceeding from the.upper side. This, by far the more abundant type of venation, is reproduced exactly in the existing species. Similar variations were noticed among the American fossils.

Known from Mull, from the Fort Union group of Dakotah, and from Greenland, ${ }^{1}$ this Fern differs strikirgly from others of the European Tertiaries. It is found everywhere in a lacerated condition, and presents great variability in its venation. Specimens brought by Mr. Whymper from Greenland were also figured by Heer, ${ }^{2}$ and should now be in the British Museum, though I am unable to find them. Their identity with the Mull Fern is considered certain by Saporta $;^{3}$ and if, as the plates show them to be, the

1 'Flora fossilis arctica,' 1868, vol. i, p. 86, described as Woodwardites arcticus from Atanekerdluk.

2 'Phil. Trans.,' 1869 , pl. xl, fig. 6.

3 The Marquis de Saporta, in a letter received since the text was in type, points out its resemblance to Pleocnemia, a group of Aspidieæ.

"Votre Fougère de Mull Filicites hebraidicus est effectivement identique avec le Woodwardites arcticus de Heer; il suffit pour s'en convaincre de comparer les figures du 'Flora fossilis arctica' avec les 
veinlets are in groups they cannot be placed in Woodwardia. Another and more abundant Fern, bearing a resemblance to it when figured, has been described in the same work as Pecopteris, Hemitelites, and Osmunda Torellii, but the specimens themselves show the Fern to have been of stronger and coarser growth.

Onoclea hebraidica is, as pointed out by Newberry, almost identical with the existing species. This is a monotypic form inhabiting the United States from Florida to Canada; Northern Asia, Amur, Japan, and Manchuria. It also somewhat resembles the more tropical genus Pleocnemia.

The specimen (Pl. XIII, fig. 5) had already been figured by the Duke of Argyll in the 'Journal of the Geological Society,' and briefly described by Prof. E. Forbes as "part of a frond, probably that of a Fern, but presenting some anomalous features which future specimens will probably explain. For the present it may be called Filicites (?) hebraidicus." Our etching represents the venation in a clearer manner than the lithograph referred to, but conveys the undulating habit less accurately. Fig. 6, selected from a large number of specimens in the Hunterian Museum of the Glasgow University, was found by Mr. Koch in 1880 .

The preceding notes embrace all the distinctly characterised species except Meniplyllum elegans, on which no additional light can yet be thrown, and therefore even its claim to be considered a Fern seems doubtful. On the other hand, one of the forms, very imperfectly figured (Pl. II, fig. 6), and placed among the "Filices incerta sedis," may prove a fragment of a coniferous leaf, possibly of Dammara.

The Ferns already mark the distinction that exists between the floras from above and from below the London Clay, the few fragments from the latter belonging to quite different forms. The Bournemouth flora alone has furnished examples of every Fern met with in England from above the London Clay, except the Marattia, that is supposing

votres. Vous pouvez donc les identifier et tirer de cette identification les résultats qu'elle comporte. Elle pourrait entrer dans les genres Aspidium et Plıegopteris, et presqu' au même titre; mais il faut remarquer que les Phegopteris ne sont réellement que des Aspidium dont le tégument avorte, et, sans fructification vous ne pouvez arriver à une détermination plus précise.

“ Vous avez d'une part $l$ 'Aspidium Leuzeanum, Kunze (A. coadunatum, Wall., 'Ett. Farnkraïter,' pl. 128, fig. 6), d'autre part vous avez le Phegopteris macrodonta, Mett., et le P. Brongniarti, Mett.; avec ces derniers le rapprochement est encore plus frappant à cause de l'extrème analogie du réseau veineux. J'ajouterai encore comme indice que parmi les espèces inédites des Gypses d'Aix (éocène supérieur) je possède une belle empreinte de penne de Fougère qui me parait se ranger fort naturellement dans ce même genre Phegopteris, non pas précisement à côté de la vôtre mais tout auprès du Phegopteris prolifera, Mett. La figure de cette espèce dans l'ouvrage d'Ettingshausen, tab. cix, fig. 2, est une réproduction presque exacte de mon échantillon, que je nomme Phegopteris provincialis, mais que je n'ai encore ni décrit ni figuré." 
the pinna described as Phegopteris pra-cuspidata to be identical with Goniopteris stiriaca, which I now think probable, and setting aside Pteris (?) Hookeri (Heer. sp.), which may be but the drawing of the enlarged lateral pinna of Pteris eocanica. It is very remarkable that of all these only one is found passing either into the Lower Bagshot or the Upper Eocene. Only three species are met with in the older beds at Bournemouth, six are added in the middle beds, five of which disappear in the upper beds and are replaced by three others.

It appears as if we had now a nearly complete knowledge of at least the Ferns of the Bournemouth stage, whose stations were woodland or marsh, for, though work during the past two years has multiplied, and in some cases produced finer specimens, no new type has been brought to light. This concluding part of the monograph on 'British Eocene Ferns,' though enabling several corrections to be made, only adds one species, and this, not because it has been newly discovered, but in view of the extreme probability that the Scotch and Irish Tertiary plants are of Eocene age.

We are able, in addition, to figure some more perfect and larger specimens of Osmunda, Plate XIII, figs. 1, 2, 3, 4, a dwarf frond of Lygodium (fig. 8) from the same, and a spccimen of Goniopteris Bunburii (fig. 7) from Lough Neagh.

The Ferns already published furnish data of considerable value, and indicate how much we may expect to learn from the remainder of the flora. Among them, three are peculiarly important through the ease with which they can be identified, for each is scarcely distinguishable from an existing and widely distributed species, yet like no other in the world. There is thus absolutely no shade of doubt about either the anthenticity of their determination or the close relationship they bear to a sharply defined existing species. No more definite data could well be imagined, and it may be instructive, even at this early stage, to reflect upon what these and other Ferns teach, before commencing a new subject. One of these cannot be separated by any specific character from the existing Chrysodium aureum, a magnificent plant with dark glossy foliage, inhabiting preferably swanipy places, and almost confined to tropical or sub-tropical regions. A description by Mosely ${ }^{1}$ of its growth in Bermuda reads like a restoration of the Eocene period at Bournemouth. "The most refreshing and beautiful vegetation in Bermuda is that growing in the marshes and caves. The marshes or peat bogs lie in the inland hollows between two ranges of hills. These bogs are covered with a tall, luxuriant growth of Ferns, especially two species of Osmunda (O. cinnamomea and $O$. regalis). Some Ferns are restricted to particular marshes. In some Acrostichum aureum grows ${ }^{2}$ densely to a height of from four to five feet. Together with the Ferns grow the juniper, which thrives in the marshes, and a palmetto, which gives a pleasing variety to the foliage."

The species seems to have arrived with the sudden increase of temperature apparent in the London Clay period, for its pinnæ are massed together in the Lower Bagshot at

1 'A Naturalist on the Challenger,' p. 23.

2 A name preferred to Chrysodium, in Hooker's 'Synopsis Filicum.' 
Studland. It maintained its ground during the physical changes of the Middle and Upper Eocene and Lower Oligocene ages, and only migrated away during the lower temperature that accompanied the deposition of the Hempstead beds. Its absence from Alum Bay and the older Bournemouth beds shows that these stations were unsuited to it, probably through want of moisture, while it was excluded from the otherwise suitable swamps of Bovey through the higher elevation of that district during the Eocene, and from the swamps of Hempstead, where a palmetto still grew, by decrease in temperature. The localities from which it is absent, no less than those in which it is present, show that this part of England must have been almost on the confines of its range, and the minimum temperature of our Middle Eocene and Lower Oligocene may be gauged to some extent from it.

The second Fern is so completely identical with the existing Osmunda javanica, that it seems merely misleading to continue to use a separate specific name for the fossil pinnæ. Notwithstanding its abundance in both a recent and fossil state, its identity remained unrecognised for twelve years by Heer, who speaks of it in 1869 as Hemitelites, closely allied to H. Torelli, of Greenland. There is little to add to our former description, though its late arrival and speedy migration from England are both remarkable. Its present range from Kamschatka to Java shows that it might have withstood, better perhaps than most tropical species, a change of temperature, and, indeed, the relatively small size of the pinnæ at Bovey, prove that it supported there a lower temperature than in the swampy tracts at Bournemouth, where the pinnæ reach nearly twice the size: Its occurrence from the oldest to the newest beds at Bournemouth, shows that it existed throughout our Middle Eocene and was not specially localised, so that its absence at Hordwell, Gurnet Bay, and Hempstead, where many of the assuciated plants of Bournemouth and Bovey survived, seems a reality. Like the Cirysodium it must, with its Cycas-like growth, have formed a conspicuous feature in the swamp vegetation of Bournemouth. Though apparently strictly a Middle Eocene Fern with us, Saporta states that it is confined to the Oligocene in the South of France, a dryer atmosphere and soil doubtless excluding it from the Eocene of Aix in Provence, while farther east, the strata in which it is found seem even newer. From this visible migration eastward it might almost be inferred that it reached its present habitat, the extreme east of Asia, and the islands to the south, from the westward, and incidentally that it failed to penetrate into Hindustan ${ }^{2}$ on its route on account of some impassible barrier. It seems likely that this Fern may be useful in fixing the age of plant remains in England, and perhaps also in the South of France, though it must not be inferred from its presence that deposits in different countries are contemporaneous, since, as a still existing species, it might occur in any tertiary or quarternary deposit where

1 Bovey-Tracey is eighty miles distant from Bournemouth, and situated among hills, whence some of the Eocene river sediment was probably derived.

${ }^{2}$ It is only met with in southern India. 
sub-tropical plants are found. From a comparison of the relative size of recent pinnæ from different latitudes with those of Bournemouth and of Bovey, the difference in temperature and consequently of elevation between the two stations might be gauged the more safely from the persiste!ncy with which the average size is maintained at each locality. Want of heat evidently excluded it, like the Chrysodium, from the Scotch, Irish, and all Northern Eocenes, though in a stunted form it is now acclimatised in Kamschatka, while the absence of both from the entire series of Swiss 'Tertiaries, shows that unsuitable conditions continuously prevailed there.

A third Fern, Onoclea hebraidica, from the basalt formation of Mull, is equally identical with a living species. A discovery made during the progress of this work, while still leaving the true age of this fornation somewhat a matter of doubt, shows so conclusively that the North British and Irish Tertiary floras are a continuation of the Eocene floras to the south, that to omit them in this work would be to omit a clue which may render possible the solution of the most interesting problems connected with past and present plant distribution.

'The floras from the Eocenes below the London Clay are remarkably lomogeneous in England, and present relatively few species. They are, as long since pointed out by Sir J. Hooker in the case of the Reading plants, of remarkably temperate aspect, the leaves and fruits of Platanus being conspicuous, among a number of undetermined prevailing types. This flora is sufficiently similar to that from the Greenland Tertiaries collected by Mr. Whymper, and different to other Tertiary floras, to show that a close relationship must have existed between them. The inference from this is obviously that as temperature increased during the London Clay period the old temperate indigenous fiora of our latitudes was driven as far north as Greenland, where it must have remained until a diminution of heat again enabled it to descend. The effect of the convergence for so long a time, of perhaps very dissimilar floras from different longitudes towards the land areas of the pole, consequent on a general rise of temperature in the northern hemisphere in Eocene time, would be to mingle the floras of three continents; so that when they redescended, quantities of new forms would almost certainly appear in each area. During nearly the entire Eocene period they were probably continuously modified in the direction of existing trees, and in that sense species no doubt did originate near the pole, as Saporta claims, and when they reoccupied the temperate latitudes of Europe it was as a Miocene flora. The recognition of an Eocene temperate flora in our latitudes, and consequently of a period when arctic conditions prevailed at the Pole similar to those of the present day, explains the universal break in the sequence of floras between Cretaceous and Tertiary, noticed all round the Arctic circle, and is also a considerable step towards a comprehension of the past and the existing plant distribution of the northern hemisphere. It fixes for the first time the ages of the Arctic Tertiary floras, and limits the period during which they could possibly have grown there to between the London Clay and the close of the Oligocene. The Mull and the Antrim floras are intermediate between 
the closely-allied English Lower Eocene and Greenland Middle Eocene floras, and they possess species in common, not only with these but with the warmer Middle Eocene flora of the South of England, and therefore must be assigned on plant evidence to an age intermediate between these periods. They must, in fact, be relics either of the passage of the Lower Eocene flora north, or of the descent of the Miocene flora south, or else the permanent Middle Eocene flora of those latitudes. Against the former supposition we have the occurrence of the flora in many localities in both Ireland and Scotland, rendering it unlikely that they all were deposited in so limited a period as that in which the change in temperature can be proved to have taken place, even if the mixture of Middle Eocene forms from the south anıong them were not conclusive. Against the second supposition we have the appearance of immense antiquity presented by the basalts, and the dissimilarity of these floras to those of the European Miocenes. It nust be remembered that there is no stratigraphical or other evidence whatever, except the floras, as to the ages of the Scotch, Irish, Icelandic, or Greenlandic plant deposits, though the colossal denudation of the basaltic formations in which they are enclosed, had led many independent observers to assign to them a far greater antiquity than the plant evidence has hitherto seemed to warrant.

Onoclea hebraidica occurs fossil at Mull, at Greenland, and in the Fort Union group of Dakotah, and it still exists unchanged as Onoclea sensibilis in the United States and on the temperate east coast of Asia. It might therefore be found among any Tertiary or more recent assemblages of fossil plants in countries in which it still lives without affording a clue to their age, and it would therefore be useless to endeavour to make its presence a test of the real age of the Fort Union group. Professor Newberry, however, made its occurrence in the American Tertiaries the basis of speculation which it now seems desirable to challenge, as the more recently ascertained distribution may be equally well read in a different sense. He considered that since this and other species, at that time common to the Old and New Worlds, have disappeared from Europe, while they continue to flourish in America, it would follow that these were American types which had colonised Europe by migration, and that when their connection with the mother country was severed they were overpowered and exterminated by the present flora of Europe, which Prof. Gray has shown to be mainly of north Asiatic origin. The occurrence of Onoclea sensibilis on the Island of Mull, while it has not been found in the Tertiary beds of other parts of Europe, indicated he believed not only an American connection during the Miocene period, but an American origin for that species. We need not here follow Prof. Newberry further, as the remainder of his essay is based on the comnunity of American and European Miocene genera, a question not directly connected with the present subject, but it is only necessary to point out that if the Onoclea occurs in older rocks in Europe than in America, as well as in the intervening Greenland, the evidence, so far as it goes, favours the theory of its migration north from Europe to Greenland during the warmer Eocene, and south from Greenland to America 
during the cooler Mioccne, thus giving it a European origin. Its cxisting distribution in Asia and America entirely favours the theory that it spread from the Grecnlandic centre, and its occurrence at Mull only traces its origin still farther back to Eocene Europe.

The following very valuable remarks by Prof. Newberry ${ }^{1}$ supplement our knowledge of this Fern :- "The collection of Dr. Hayden contains a great number of examples of this beautiful Fern, showing the upper and under surface of the frond, the variation of form of the pinnæ of different fronds, and different parts of the same frond. The robust habit of this plant, the strong, waved and reticulated nervation, and broadly waved rachis, which seem to distinguish it at a glance from all known fossil species, suggested a comparison with some of the strong-growing tropical Ferns; and it was only after a laborious examination of all the genera of exotic Ferns contained in the herbaria to which I had access, or described by authors, that I was led to turn my eyes nearer home. The common form Onoclea sensibilis grows abundantly in all parts of our country, and is one of the first plants collected by the youthful botanist. In this we have the rachis of the frond more or less winged, and a nervation on the same general plan with that of the fossil before us, but more distinctly reticulated. By this I was at first misled, but in examining Dr. Torrey's var. obtusilobata, I found in some specimens the exact counterpart of our fossil in the lobation of the pinnæ and nervation. The gradation of characters in this variety is very great and interesting. In some specimens we have a distinctly bipinnate frond; the pinnæ composed of numerous remote, even obovate, pilnules, and the nervation not reticulated, the nerves of the pinnules radiating and forked, but never joining." The agreement in character with our fig. 5 is very remarkable, and but for these remarks I should have remained ignorant of the existence of a living representative of this variety of our fossil species, for no examples are preserved in the Kew Herbarium. Prof. Newberry continues:- "This is the extreme form, but even here the rachis of the frond is more or less winged. In an intermediate form we find the rachis winged, the pinnæ deeply lobed, and precisely the nervation of the fossil. Even in the common form the nervation is similar in plan, and the elongated spaces, destitute of nerve branchcs, on either side of the rachis of the pinnæ, form a noticeable feature in both. There is little room for doubt, therefore, that during the Miocene age a species of Onoclea flourished in the interior of our continent, of stronger habit than either of the living varieties, and holding a middle position between them. This fact suggests the question, whcther they could not have been differentiated from it."

"Varying, as the living Onoclea does, in the size, outline and nervation of the sterile frond-from six inches to three feet in height, from a finely reticulated to all open, dichotomous nervation; from a bi-pinnate frond with remote, obovate pinnules to a pinnate form with wave-margined pinnæ and broadly alate rachis-it plainly includes all the characters of the fossils before us, and I therefore find it impossible to separate them." 
This description applies equally to the Mull form, about fifteen specimens of which I have examined. They, except fig. 5, were all found by Mr. Koch in 1980, and include facsimiles of the forms of lobation and venation seen in the existing species, while their texture and preservation led me to anticipate a living representative with membranaceous fronds and fine, distinct black veins. The fertile fronds, as in nearly all Ferns in which these are separate and unexpanded, are unknown fossil, and we have here the only pretext which can possibly be held to justify the continued separation of the Tertiary forms of at least the Chrysodium, Osmunda and Onoclea just described, from the surviving species.

The distribution of the Bournemouth Gleichenia is at present the most restricted of any fossil Fern that has been met with at all plentifully, for it is absolutely confined to the small local patch near which it grew. Its peculiar climbing growth has been sufficiently described and is no longer met with in living Gleichenias. The Anemia, a graceful and well-marked Fern, seems a survival from the Cretaceous period, since extinct, and to have been descended from a northern pre-eocene group. From the plants with which it is associated at Bournemouth, it appears to have been epiphytal, occupying the same position that the not very dissimilar Davallia does in the moist and luxuriant forests of Madeira at the present day. The Lygodium, associated with it at Bournemouth, undoubtedly occupied similar stations. It possessed larger and more variable fronds than the Anerican species most resembling it, and which seems to have become but recently acclimatised to the temperature it now supports in the United States, since it would probably otherwise have been found in some of the more northern Eocene floras, The much smaller size of the fronds in the Swiss Miocene show, perhaps, that a change was even then in progress. The Hewardia, a remarkable form of Adiantum with anastomosing venation, probably possessed habits analogous to those of $A$. reniforme at present. It, like the Anemia, Lygodium, Marattia, Phymatodes, and several others, can only be looked upon as extinct species, whose resemblance to tropical American, rather than to any other living species, is a fact that acquires significance through the accumulation of instances.

The only Ferns among them resembling existing European species are Pteris eocenica, P. Bournensis, and Adiantum apalophyllum, but the wide range and the number of species contained in the corresponding types at the present day, render it difficult with our material to identify them more definitely with one than another. The Goniopteris section of the Polypodica, of which three species were described, would perhaps be more correctly represented by two, through the union of G.pra-cuspidata and G. stiriaca. The latter had apparently a northern range, though the remains are not very distinct, and from the variation among them it is possible that several species or genera are included under the same name. The British species was able to thoroughly establish itself at Bovey-Tracey, but not, so far as we yet know, elsewhere in either England or France, though it abounded in Switzerland. G. Bunburii is easy to identify notwithstanding that the vena- 
tion is of a usual type. From its restricted vertical range at Bournemouth, and its presence at Bovey, it might be inferred that the former locality marks almost its extreme southern range at that time, while northward it reached to Antrim, which may also have been near its limit, since it is apparently absent at Mull. It was evidently a woodland and not a marsh Fern, and its exclusion from Hordwell and Hempstead on this supposition is natural. The importance of the discovery of the Irish locality lies in the fact that it helps to link the Bournemouth Eocenes with those of Antrim, which are themselves linked to the Greenland Tertiaries. I have re-engraved (Pl. XIII, fig. 7) the original specimen figured by Mr. Baily in the 'British Association Reports' for 1880, pl. 2 fig. 1. It was fornd in an ironstone pebble among silicified wood on the shores of Lough Neagh, and though undescribed, the name of Hemitelites Fraseri is attached to it.

All these species are obviously divisible, through the plants associated with them, into marsh Ferns and woodland Ferns, while some which have the greatest range were evidently not entirely excluded from either station. Examples of the latter are the Chrysodium and Osmunda, remains of which occur in the greatest profusion, mingled with palmettos and other swamp plants, but which are also found with distinctly forest vegetation. Examples of woodland Ferns are the Lygodium, Anemia, the two Adiantums, \&c. Goniopteris Bunburii, a parely woodland Fern at Bournemouth, existed perhaps in a lower temperature with a damper station at Bovey, while G. stiriacaluxuriated as a marsh Fern at Bovey, but has only been met with once among forest leaves at Bournemouth. It will perhaps be safer, however, to defer these and other inferences until more plants have been described. With the exception of the last-named Fern and the Osmunda, which we have seen shows evidence of relatively lower temperature, the higher elevation at Bovey seems to have excluded the contemporary Bournemouth Ferns, or rendered them rare.

While we apparently know much respecting the Ferns of the British Eocenes, compared with what is known of those from the Tertiaries of other countries, several considerations tend to show how insufficient and how incomplete is our grasp of the subject. The present inability to explain the restricted range of so many Eocene Ferns, such as Phymatodes, for which there is no apparent reason, the absence of any trace of such widely distributed and ancient forms as Dicksonia, Asplenium, Lomaria, and Todea, throughout almost the whole Tertiary period; the failure to detect any trace of the fertile pinnæ of so many and such comparatively abundant Eocene Ferns, and the vague knowledge possessed of some other forms, renders the present portion of our work far from satisfactory, and has shown the necessity of a more attentive consideration than it has received.

In comparing our fossils with those of other countries in Europe, we see that even the Ferns may afford some clue to the relative sequence of many of the plant-bearing beds, whose ages cannot be ascertained stratigraphically. The presence, in the Cretaceous series of Aachen, of Jurassic types, now confined to distant isles, indicates their relative antiquity. The presence of a portion of the least archaic of the Aachen types at Sézanne, 
and the absence of all but the oldest of the Bournemouth types, mark out roughly the age of a deposit, further distinguished, alone among Eocene floras, by the presence of tree Ferns, referred by Saporta to the genera Hemitelia and Cyathea, ${ }^{1}$ and interesting because existing trce Ferns do not penetrate farther north than the moist valleys of the Himalaya. The flora of Gelinden contains no Ferns common to our Middle Eocene, but may be found to present affinities with our Lower Eocene flora. The Grès du Soissonnais posssesses a flora approching that of Alum Bay, and Chrysodium Lanzceanum is common to it and to our Lower Bagshot. The distinctly Middle Eocene types first appear in France in the Eocene of Aix, many of them, however, being kept away, probably through a dry climate, until the beginning of the Oligocene. Without pursuing these comparisons further, it is evident that our Eocene and Oligocene Ferns appeared in a definite order, and are, when contrasted with those of the rest of Europe, singularly tropical and luxuriant, suggesting, indeed, that England was then situated in the line of some warm current or under exceptionally favorable meteorological conditions.

In comparing the Eocene Ferns with those of the Arctic regions, the absence there of all the sub-tropical types met with in England is very striking. The absence of Adiantum, for there is nothing in the Adiantites of Heer to prove affinity with Adiantum, shows the nature of the climate, for one species now ranges as far north as the Jura, Tyrol, and south-west of England, where it withstands considerable frosts, while others are found at a height of 6000 to 8000 and even 9000 feet in the Himalayas. Equally significant is the absence of the type of Pteris eocanica, for it is present in nearly all similar beds in Europe and America, and is now but little less hardy than Adiantum, standing even severe frost, and extending, according to Hooker, to 9000 feet in the Himalayas. Another instance is seen in Woodwardia radicans, a type of which abounded in the Tertiaries of Austria, Switzerland, and America. The gradations in temperature were then, in fact, as pronounced as they are in some equally separated tenıperate latitudes at the present day.

In comparing them with the Tertiary American Ferns, we find two even among the very fow yet described from the Great Lignitic series, which are certainly specifically identical with our own, and these are the two oldest types. They are also accompanied by representative, if not identical, species of the following European Tertiary Ferns :Splienopteris eocanica, Pteris pennaformis, Woodwardia Rössneriana, Goniopteris. stiriaca, and Osmunda IIeerii. It is thus remarkable that the Eocene Ferns of America are much less tropical in aspect than those of Europe at the same period, and consequently more resemble those of the Miocene of Europe. The temperature of the western hemisphere seems to have remained colder throughout the Tertiary period than ours, and hence its floras seem to have preceded ours, and present a relatively newer facies. While it is just possible that these Ferns may have passed over, or descended

1 A pinua of Osmunda lignitum was figured, 'Ann. Mag. Nat. Hist.,' ser. 4, Jan., 1869, vol. iii, pl. i, fig. 5, by Mr. A. Wanklyn, with the remark that it seemed allied to some genus of Cyathere. 
from, northern latitudes, the knowledge we already possess of the Arctic and North American fossil floras effectually takes away every ground for supposing that the strong relationship between the Neo-tropical Fern flora of the present day and that of our Eocene could have been due to any land communication north of latitude $50^{\circ}$.

The relationship of our own Eocene Ferns to the present subtropical American flora is apparent from the fact that of seventeen types all but one are known in it. A connection less in degree is seen between them and the Ferns of Eastern Asia and Java, where six only of the types are absent. Scarcely any of the Middle Eocene types have remained in Europe, except Pteris cretica and Adiantum, for those related to Osmunda regalis and Woodwardia radicans seem only to have reached Central Europe from the north during the Miocene. The Eocene forms of Marattia, Anemia, Gleichenia, Phymatodes, and Hewardia were the first to disappear, and it is remarkable that these happen to differ most widely from their living representatives. Few of the present European Ferns can be traced back to fossil ancestors, even among those of the Arctic regions, while they seem so closely connected with the living Ferns of North America, that of our thirty-six British species, all except three of Neplrodium and Asplenium lanceolatum and $A$. germanicum, also exist there.

No more is sought for than to claim for such inferences and conclusions as have been arrived at, that they seem warranted by the results of the work so far. There are, however, in all probability living Ferns still undiscovered, and we are as yet certainly acquainted with but a fraction of the Eocene Fern world. Still, however incomplete the data for interpretation may be, the possibility that something may come to light in the future to change or modify views based upon our present knowledge, does not deprive them of current value. The interest attaching to these Ferns is increased by the fact that while the higher orders of plants from the Tertiaries have formed the basis for much speculation as to former temperatures, distribution, \&c., the inferences to be drawn from Ferns have hardly been taken into account.

Amidst inference and hypothesis, the fact at least is certain, that there is no real break between Eocene and Miocene floras when they are traced over many latitudes. The supposed Miocene floras of the Arctic Circle are, we shall see, but modified temperate Eocene floras which had migrated north when warm conditions set in, and which redescended south, still further modified, when the decrease of warmth during the Miocene again permitted them to do so. The results that followed the forced convergence towards the land areas of the Pole of perhaps very dissimilar floras from long separated lands of different longitudes, through a general increase in the Eocene temperature of the Northern hemisphere are as yet faintly sketched and perplexing, but with patience they can be unravelled. At present it can only be stated that when they redescended as Miocene floras, they were greatly modified and enriched in genera and species. 



\section{INDEX OF FOSSIL SPECIES.}

(The accepted British fossil species are in italics, the rest are synonyms or closely allied foreign species.)

Acrostichum, p. 28 ; see also Chrysodium.

Adiantum apalophyllum, pp. 42, 57,61, 76, pl. x, fig. 1 ; pl. xii, fig, 7 . formosum, p. 61 .

Anemia Kaulfussi, p. 47.

" subcretacea, pp. $45,58,67,68,76$, pls. viii and ix.

Aspidium lignitum, pp. 50, 52, fig. 23.

" Meyeri, p. 50.

Asplenites allosuroides, pp. 35, 68 .

" præ-allosuroides, pp. 34, 68, pl. iii, figs. 1, 2.

Asplenium Dicksonianum, p. 67.

" Foersteri, pp. 47,67.

", hyperboreum, p. 67.

„ Johnstrupi, p. 67.

" Martinsi, p. 47.

"Nordenskiöldi, p. 67.

" subcretaceum, p. 45.

Blechnum Braunii, p. 33.

Chrysodium Lanzœanum, pp. 26, 58, 65, 76, 78, pls. i, ii, figs. $1-4$.

Didymosorus, p. 59.

Dryandra rigida, pp. 50, 52, fig. 22 .

Filices incertæ sedis, pp. 55, 56, fig. 27, pl. ii, fig. 6 ; pl.x, fig. 7 ; pl. xii, fig. 9.

Filicites hebraidicus, p. 68 .

Fortisia Lanzænum, p. 26.

Gleichenia Hantonensis, pp. 43, 57, 59, 76, pl. vi ; pl. x, figs. 2-4.

Glossochlamys transmutans, p. 31 (Acrostichum?, 65), pl. iii, fig. 3 ; pl. xii, fig. 8.

Goniopteris Bunburii, pp. 38, 39, 57, 63 (Struthiopsis ?, 64), 71, 77, pls. v, x, figs. 9, 10 ; pl. xiii, fig. 7 .

"stiriaca, pp. $37,39,58,76,78$, figs. 17-21.

Gymnogramma Gardneri, p. 28.

" Haydenii, p. 45. 
Hemitelia, p. 51.

Hemitelites Fraseri, p. 77 .

Torellii, pp. 70, 72.

Hewardia regia, pp. 42, 57, 62, 76, pl. ii, fig. 5 ; pl. vii, fig. 2 ; pl. x, fig. 6 ; pl. xi.

Lastræa Bunburii, see Goniopteris.

" dalmatica, p. 40.

" Helvetica, p. 39.

" stiriaca, see Goniopteris.

Lindsaya, p. 62.

Lygodium exquisetum, p. 48.

" Gaudini, p. 49.

" Kaulfussi, pp. 47, 58, 67, 71, 76, pl. vii, except fig. 2 ; pl. x, fig. 11 ; pl. xiii, figs. 8, 9.

" neuropteroides, p. 47.

, parvifolium, p. 48.

Marattia Hookeri, pp. 54, 58, 68, 76, 79, pl. xii, fig. 1-6.

Meniphyllum elegans, pp. 36, 70, pl. iii, figs. 10-14.

Mertensites crenata, p. 43.

$" \quad$ Hantonensis, p. 43.

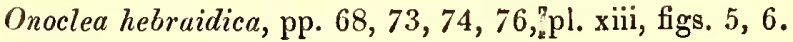

" sensibilis, pp. 68,74 .

Osmunda Dowkeri, pp. 50, 53.

$"$ eocænica, p. 33.

" Grutschreiberi, p. 50.

" Heerii, pp. 58, 65, 78 .

" lignitum, pp. $49,66,71,72,76,77$, fig. 24 ; pl. iv, figs. $1-3$; pl. xiii, figs. $1-4$.

" Obergiana, p. 65 .

$" \quad$ petiolata, p. 65 .

" Torellii, p. 70.

Osmundites Dowkeri, pp. 50, 53, 65.

Pecopteris angusta, p. 49.

$" \quad$ crassinervis, p. 49.

" Hookeri, pp. 33, 54, fig. 25.

" Leucopetræ, p. 49.

$״ \quad$ lignitum, pp. $39,49,50$.

" Torellii, pp. 52, 70 .

Phegopteris Bunburii, p. 38.

$" \quad$ Helvetica, p. 37.

" polypodioides, p. 37.

, præ-cuspidata, pp. $37,71,76$, pl. iv, figs. $8,9$.

" stiriaca, see Goniopteris.

Phymatodes polypodioides, pp. 29, 58, 64, 76, 79, pl. iii, figs. 4-6, 9 ; pl. xii, fig. 10.

Podoloma affine, p. 30, pl. iii, figs. 7, 8 .

" polypodioides, pp. $29,58,64$.

Polypodites stiriacus, p. 39. 
Pteris Aquensis, p. 34.

"Bournensis, pp. 33, 57, 63, 76, pl. iv, fig. 7 .

" caudigera, p. 34 .

" eocanica, pp. 32, 57, 62, 71, pl. iv, figs. 4-6; pl. xii, fig. 11 .

", erosa, p. 32.

" Gaudini, pp. 32, 54.

" gladifolia, p. 62.

" Hookeri, pp. 54, 71, fig. 25.

" Eningensis, p. 34.

” parschlugiana, pp. 32,54 .

" pennæformis, pp. 27, 32, 54, 78 .

" Prestwichii, p. 53, pl. x, fig. 8 .

" pseudopennæformis, pp. 33, 54.

,, subsimplex, p. 32 .

, urophylla, pp. 27,34 .

Sphenopteris eocænica, pp. 67, 78.

Woodwardia Rœssneriana, pp. 41, 57, 63, 78.

, venosa, pp. 41, 63 , pl. x, fig. 5 .

Woodwardites arcticus, pp. 63, 68. 


\section{INDEX OF LIVING FERNS.}

PAGE

Acrostichum aureum, fig. $11.27,57,58,65,71$

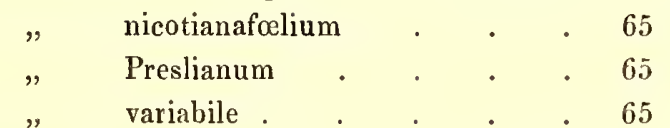

Adiantum capillus-veneris . . . 42,57,61

„ reniforme . . . . . 76

Anemia adiantifolia . . . . $47,58,67$

Aspidium macrophyllum . . . . 31

$"$ pachyphyllum . . . . 31

, trifoliatum . . . . . 31

Asplenium dimorphum . . . . . . 56

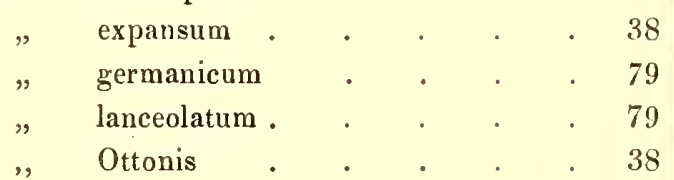

Chrysodium aureum, see Acrostichum aureum.

" vulgare, see Acrostichum aureum.

Cyathea

Davallia

Diplazium . . . . . . 38

Gleichenia dichotoma . . . . 44,57,59

$"$ glauca . . . . . 61

, pectinata .. . . . . 44

" hardy species . . . . 61

Goniopteris proliferum . . . . 41, 58, 64

, diversifolium . . . 57,64

" tetragonum . . . . 64

Gymnogramma leptophylla . . . . 35

," villosa . . . . . 37

Hewardia Wilsoni . . . . 43, 57,62

Lindsaya sagittata $\quad . \quad$. $\quad . \quad$. $\quad$. 43

Lorinseria . . . . . . 41,63

Lygodium dichotomum . . . $\quad 67$

" palmatum . . . 49, $57,58,67$

Nlarattia Kaulfussii, fig. 26 . $\quad$. $55,58,68$

Meniscium longifolium, fig. 14 . $\quad$. $\quad$. 36
PAGE

Mertensia . . . . . . . 44

Nephrodium amboinense . . . . 64

" British species . . . . 79

Onoclea sensibilis . . . . 69,74

Osmunda cinnamomea . . . . 38,71

" Claytoniana . . . . . 38

„ Javanica . . 52, 57, 58, 66,72

$" \quad$ regalis . . . $53,58,71,79$

Pellæa . . . . . . 35

Phegopteris cuspidata, fig. 15 . . $\quad 37,38$

Pliymatodes geminatum . . . 58,64

," hemionitideum . . 29, 31

$" \quad$ lycopodioides, fig. 12 . . 29,64

" persicariæfolium . . 29,64

, salicifolium $\quad . \quad$. $\quad . \quad 29$

" stigmaticum . . . . 64

$" \quad$ transparens $\quad . \quad . \quad . \quad 29,31$

Pleocnemia . . . . . $\quad$. 70

Polypodium bifrons . $. \quad . \quad . \quad .56$

" serpens . . . . . 56

Pteris aquilina . . . . . $34,57,63$

, crenata, fig. 13 . . . . . 32

" cretica . . . . $32,57,62,79$

, decurrens . . . . . 41

, denticulata . . . . 41

, heterophylla . . . . . 35

, patens . . . . . 41

" pellucida . . . . . . 62

” scaberula . . . . . . $\quad . \quad 35$

", Woodwardioides. . . . 41

Struthiopsis . . . . . . 64

Thyrsopteris . . . . . 35,46

Woodwardia areolata . . . . $\quad 41,63$

, Harlandii . . . . . 63

, radicans . . $41,57,63,78,79$ 


\section{GENERAL INDEX.}

Aachen, see Aix-la-Chapelle.

Aix-la-Chapelle $\quad 9,33,34,45,47,49,67,78$ Aix, Provence . . . 28, 34, 45, 48, 78 Alum Bay flora . . . $\quad$. $3,13,16,55,68$ American fossil flora $\quad$ • $3,47,65,67,69,78$ Antrim flora . . . . 5, 54, 77 Aquitanian beds . . . 27, 28, 32, 41, 52,65 Arctic fossil floras, $8,56,61,63,65,67,69,73,74$, 78,79 Armissan . . . . . . 61 Atanekerdluk . . . . . 40,64,65 Australiau flora

Bagshot flora, see Flora of.

Bembridge flora . . . . . . 20

Bournemouth flora . . . . . 16

Bovey flora . $5,18,38,39,47,50,54,72,73,77$

Bowerbank . . . . . . 4, 12, 14

Bracklesham . . . . . . 13

Brodie, P. B. . . . . . . 13

Bromley . . . . . . . 10

Carruthers . . . $\quad 7,16,28,31,35$

Céreste . . . . . . . . 49

Classification, Ettingshausen's , . . 22

" Hooker's . . . . 57

Corfe flora .

$4,13,16$

Cretaceous flora see also Arctic floras.

Crié $"$ see also Arctic floras.

. .40

De Bey . . . . . . $33,47,49,59$

De la Harpe . . . . . 10,14

Difficulties in determination

Disappearance of Eocene flora . . . 7

Dixon's Geology of Sussex . . . . 15

Dulwich
Flora of Bagshots . . . 12

, Lower Bagshot . . . . . 3, 16

, London Clay . . . . 3, 11,71

, Middle Bagshot . . . . 3, 16

, Oldhaven beds . . . 10

, Thanet beds . . . . .

"Upper Bagshot . . . . 19

" $"$ Eocene . . . . 19

"Woolwich and Reading beds . . 29

Forbes, Edward . . . . . 4, 13, 20

Fort Union beds . . . . . 69, 74

Gelinden . . . . . 33,78

Greenland, see Arctic floras.

Grès du Soissonnais . . . . . 78

, de la Sarthe. . . . . 48

Headon flora . . . . . . 19

Heer . . . . . . 19, 28, 72

Hempstead flora - . . . . 20,72

Hooker, Sir J. . . . 9, 31, 56, 73

Hordwell flora . . . . . 20, 28

Irish Eocenes, see Antrim.

Keeping, Hy. . . . . . . 1

Komeschichten, see Arctic floras.

Lesquereux . . . . . 3, 28, 47, 18

Lignitic of America, see American foss. floras.

Lindley and Hutton . . . . . 9

London Clay . . . . . . . 3, 11

Lough Neagh . . . . . . 71,77

Lower Bagshot . . . . . . . 3, 16

Manosque . . . . . . 19, 27,33

Mantell . . . . . . 13

Middle Bagshot . . . . . . . 3, 16

Monte Bolca . . . . . . 14

"Promina . . . . 27, 28, 33, 41

Mull flora . . . . . $5,69,73,74$ 


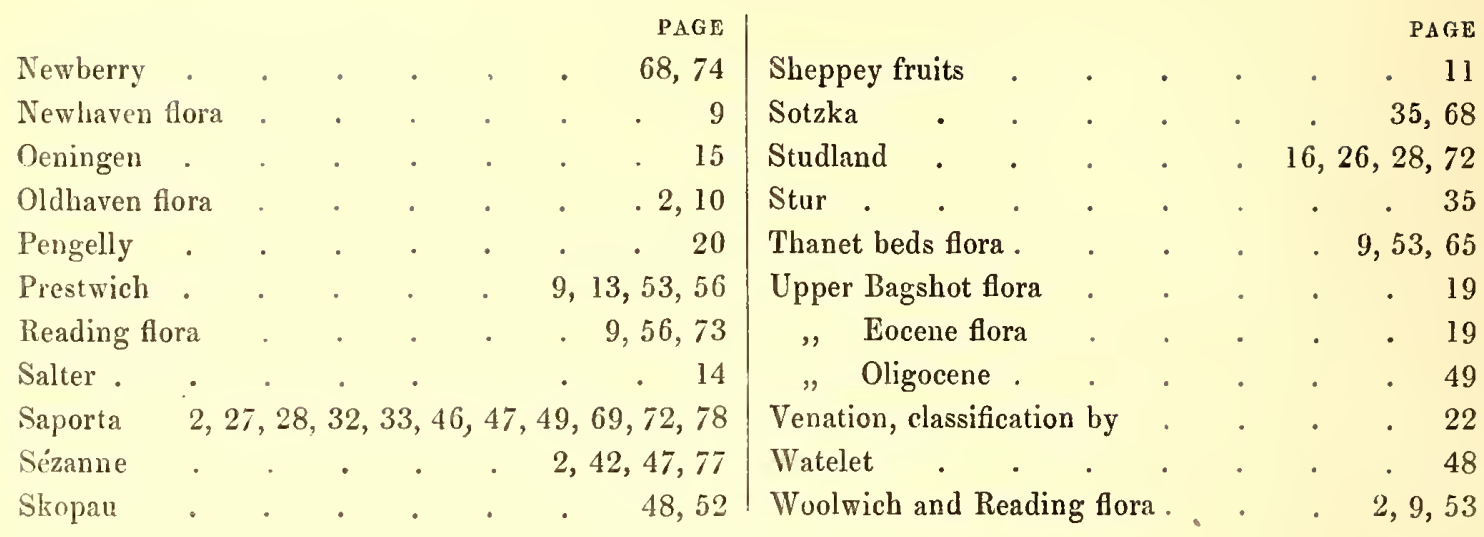




\section{PLATE I.}

From the Middle Bagshot Beds, Bournemouth.

Chrysodium Lanzaanum (Visiani).

Fig. 1. A unique specimen, with pinnæ attached. (Gardner Collection.) 


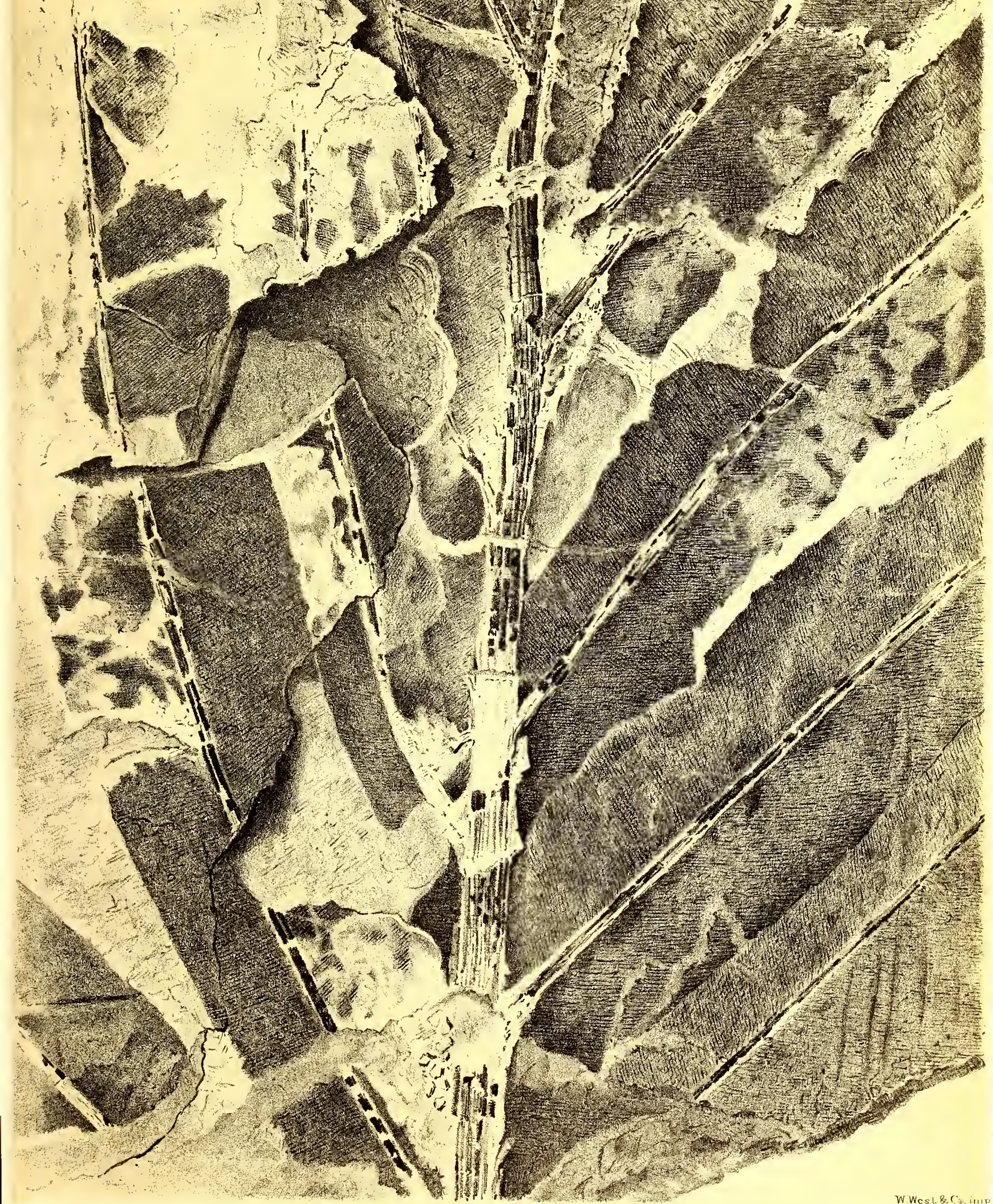

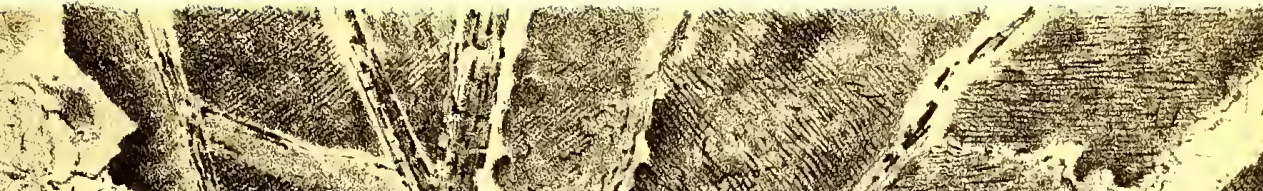


. 



\section{PLATE II.}

From the Lower Bagshot Beds of Studland, and the Middee Bagshot Bed of Bournemouth.

\section{Chrysodium Lanzœeanum (Visiani).}

Fig. 1. Fragment of a pinna, from Bournemouth.

la. Portion of the venation, magnified.

2. Terminal pinna, from Bournemouth.

2 a. Portion of the venation, magnified.

3. Apex of a pinna, with unusually close venation, from Studland.

3 a. Part of the same, magnified.

4. Fragment of a pinna, from Studland, with few anastomosing ternary veins.

(All the above from the Gardner Collection.)

Filices incerta sedis.

๖. Adiantum? (From Mr. Pender's Collection.)

6. Leaf with Cyclopteris venation. (British Museum.) 

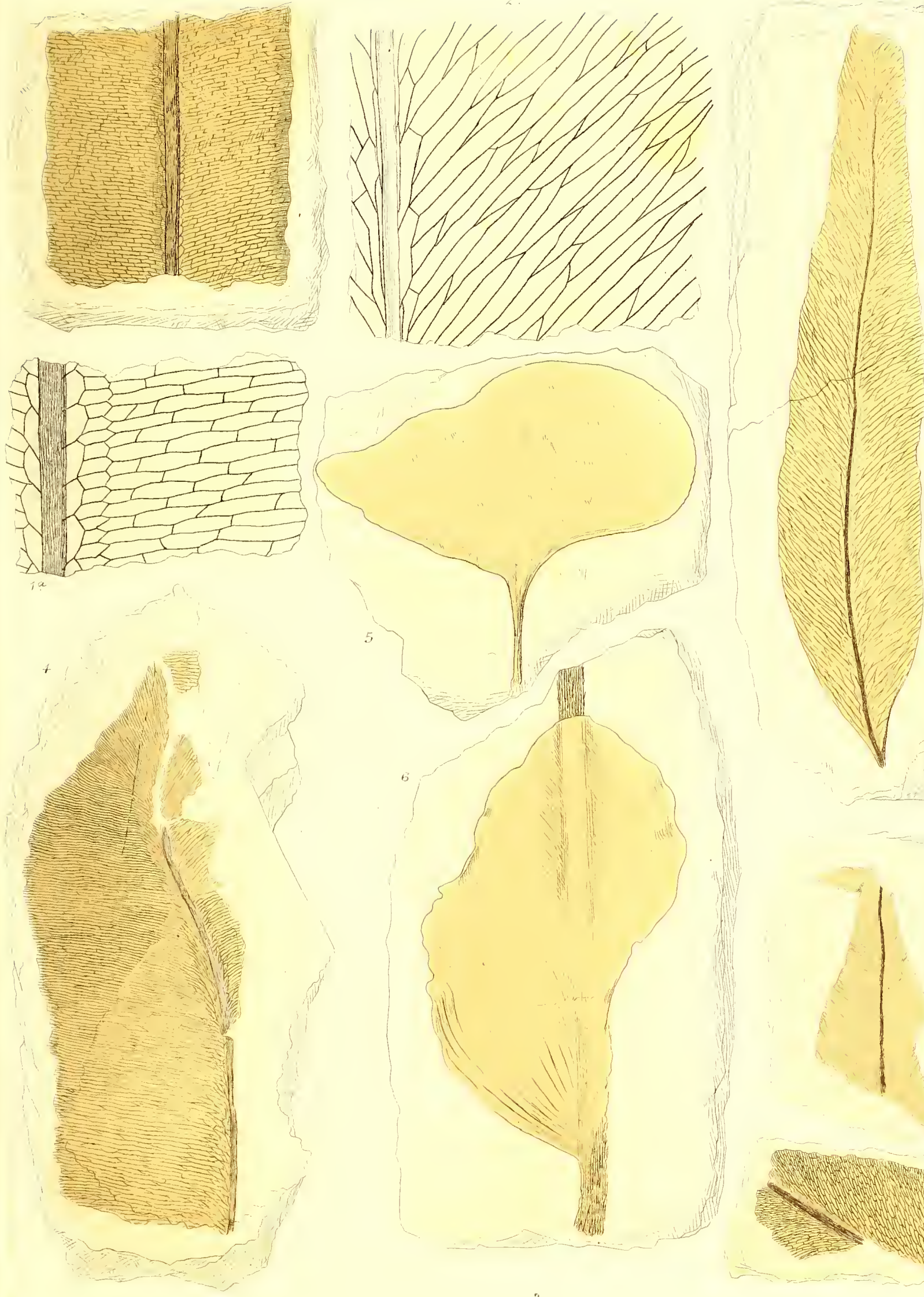




\section{PLATE III.}

From the Middle Bagshot Bejs, Bournemouth.

Asplenites pra-allosuroides, Ett. and Gard.

Fig. 1. Part of frond, magnified. (British Museum.)

2. The specimen, natural size.

"

\section{Glossochlamys transmutans, Ett. and Gard}

3. Frond, natural size. (Gardner Collection.)

Podoloma polypodioides, Ett. and Gard.

4. A pinna, of average size.

9. A shorter pinna.

5. The base of a pinna, magnified, showing sori.

6. Fragment, magnified, probably of a different species, showing impressions of sori. (Gardner Collection.)

Podoloma affine, Ett. and Gard.

7. Fragment of pinna.

8. The same enlarged, showing bases of attachment of the sori. (Gardner Collection.)

Meniphyllum elegans, Ett. and Gard.

10. A small pinna, nearly perfect.

11. The base of a larger pinna.

12. A fragment of a still larger specimen.

13. A portion of the venation, magnified.

14. Slightly shrivelled pinna. (Gardner Collection.) 

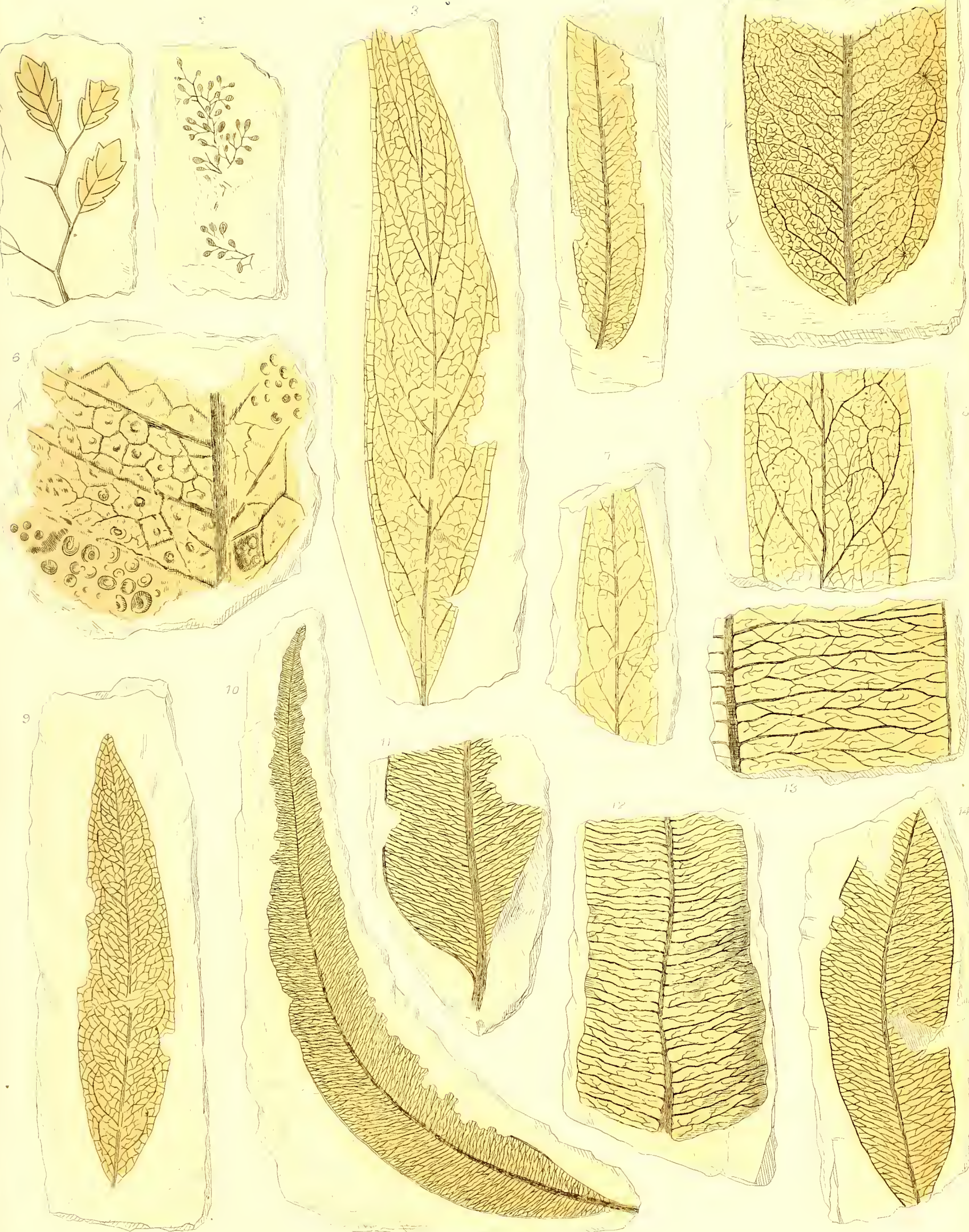




\section{PLATE IV.}

From the Middle Bagshot Beds, Bournemouth.

Osmunda lignitum (Giebel).

Fig. 1. Pinna, natural size.

1 a. The same, magnified.

2. A small pinna, natural size.

3. A pinna, natural size. (Gardner Collection.)

Pteris eocanica, Ett. and Gard.

4. Portion of frond, with pinna attached to the rachis, natural size. (Gardner Collection.)

5. Terminal portion of a stunted frond, natural size. (From the Collection of Mr. A. Baldry.)

6. Terminal pinna, average size.

$6 a$. Part of the same, magnified. (Gardner Collection.)

Pteris Bournensis, Ett. and Gard.

7. Pinna with pinnules, natural size.

7 a. Part of the same, magnified. (Gardner Collection.)

Phegopteris pra-cuspidata, Ett. and Gard.

8. A unique pinna, natural size.

9. Portion of the reverse of the same specimen.

9 a. Part of the same, magnified. (Gardner Collection.) 


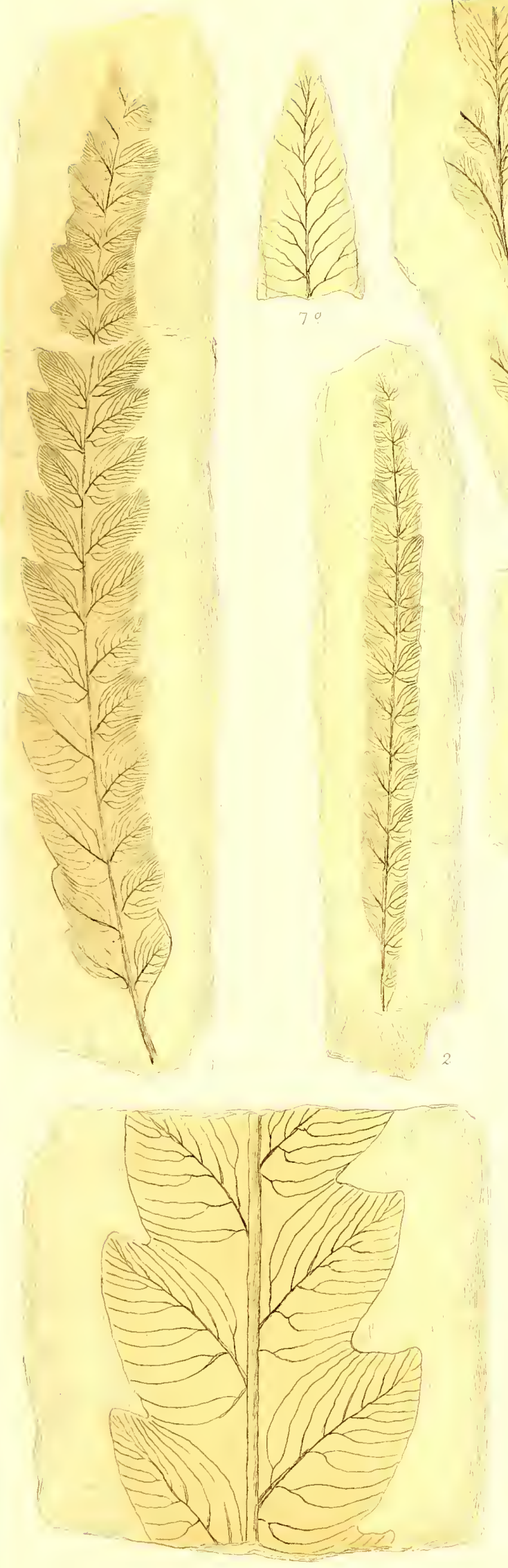

WVy
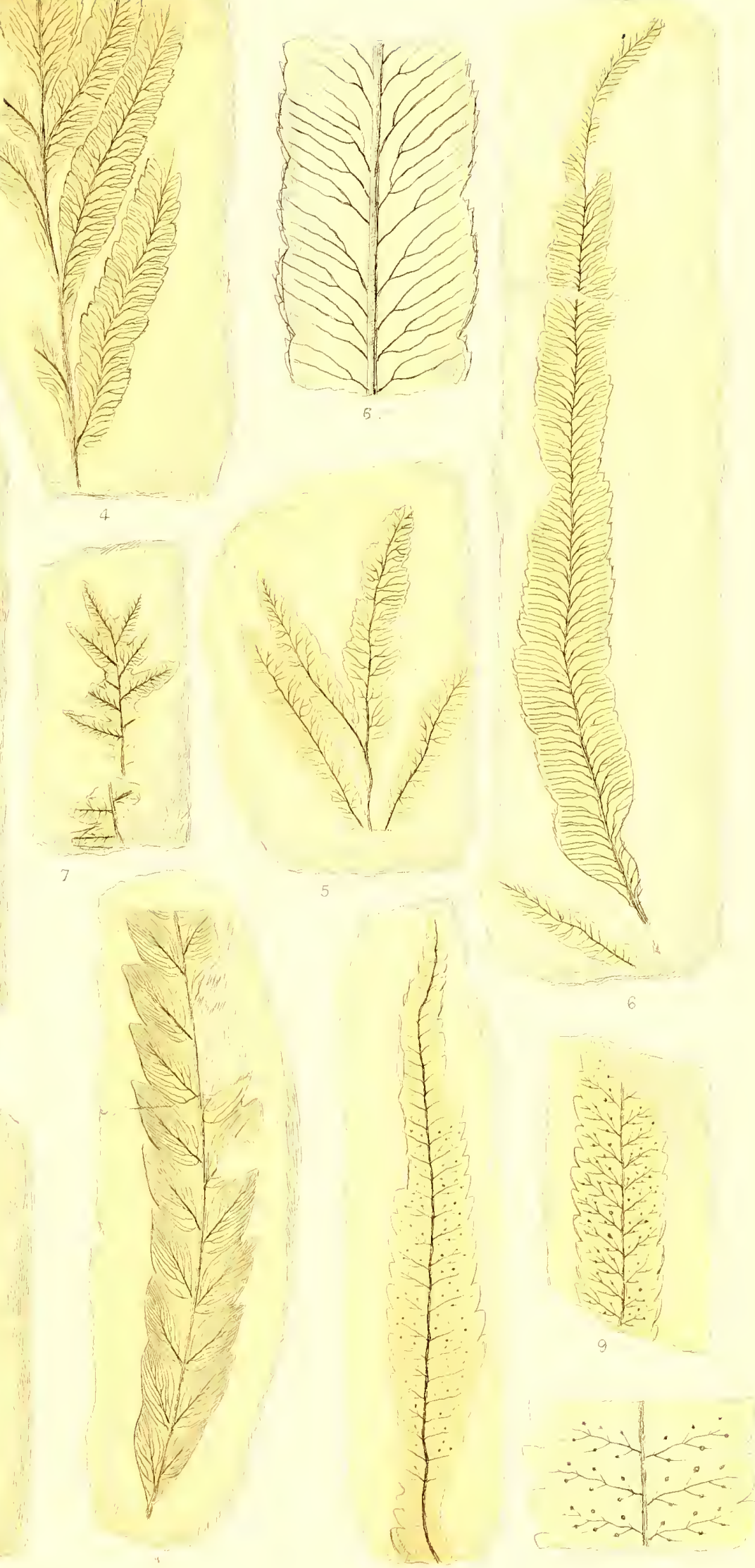
. 



\section{PLA'IE V.}

From the Middle Bagshot Beds, Bournemouth.

Phegopteris Bunburii, Heer.

Fig. 1. A young plant, natural size. (Gardner Collection.) 


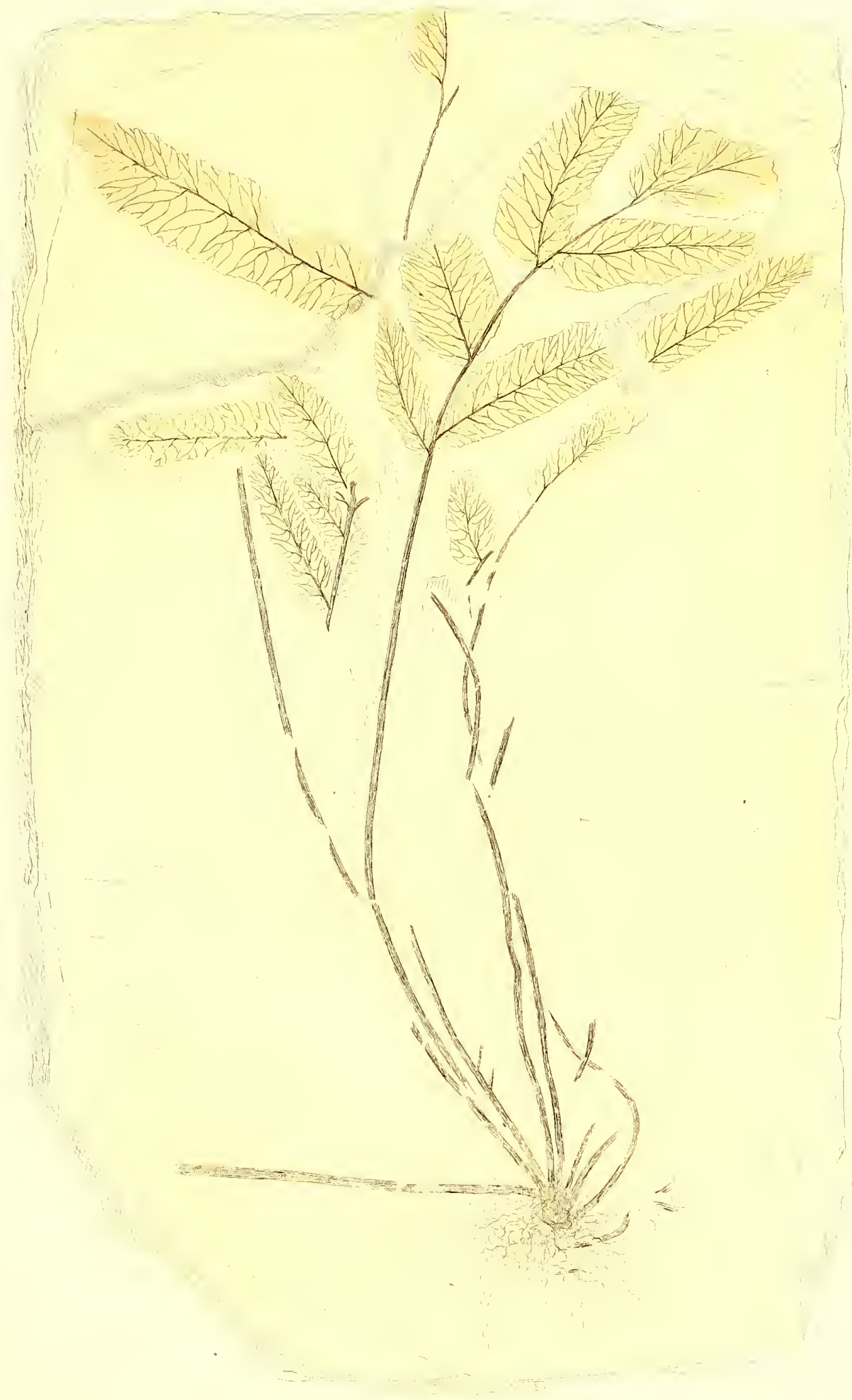




\section{PLATE VI.}

From the Middle Bagshot Beds, Bournemouth.

Gleichenia Hantonensis (Wanklyn).

Fig. 1. Portion of pinna. (From Mr. Wanklyn's Collection.)

2. Another specimen showing the apex. (From Mr. Pender's collection.)

3. Another, showing the base of the pinna. (From Mr. Wanklyn's collection.)

$4,5,6$. Details of above magnified, showing variations in the venation and pits left

by sori. (Figs 4 and 6 Mr. Wanklyn's Collection, fig. 5 Mr. Peuder's.)

7. The apex of a pinna.

8. Part of the stipes.

9, 10. Fragments with hook-like tendrils.

11. Tendrils and vernation. (Figs. 7 to $\mathrm{ll}$ in Gardner Collection.) 

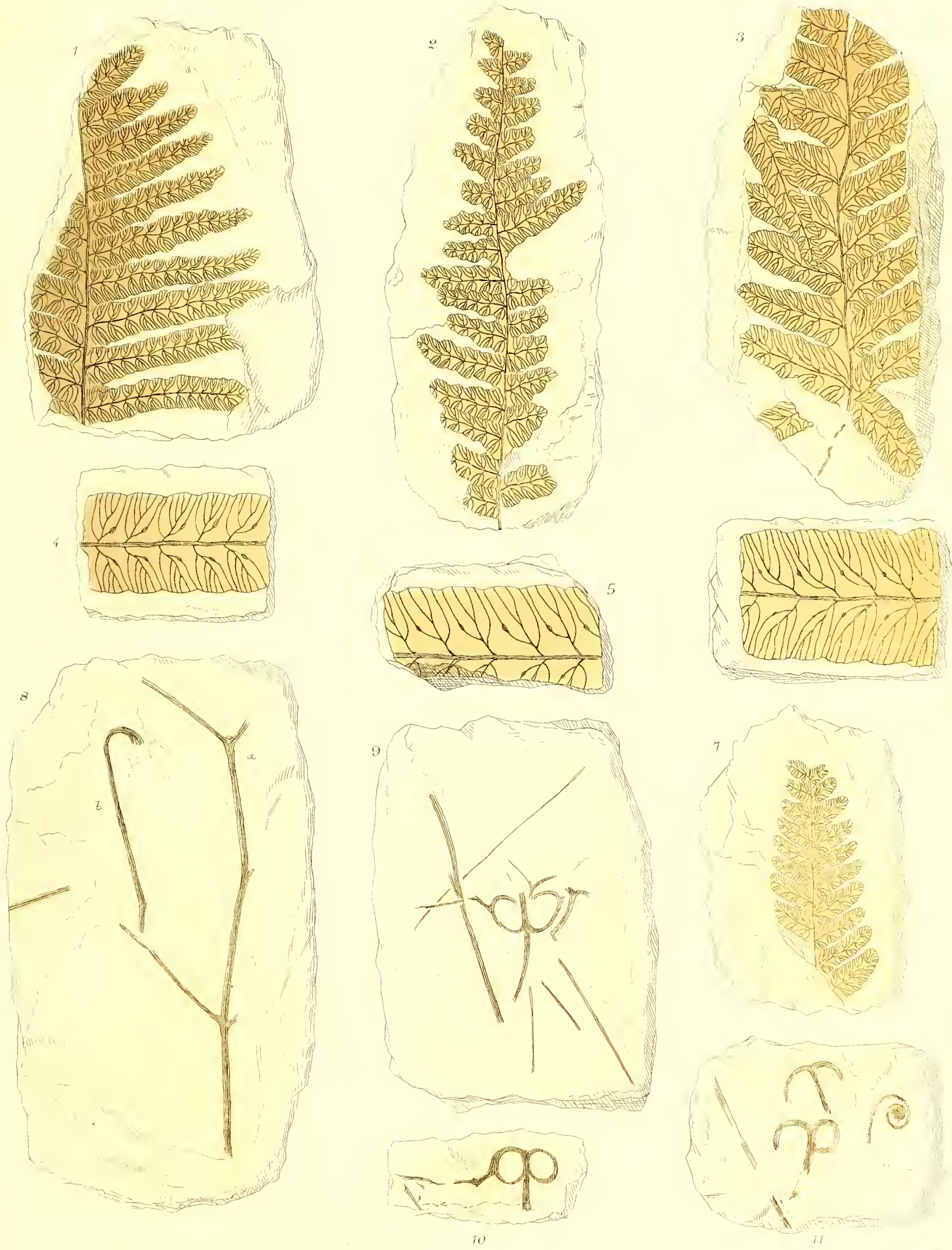
, 



\section{PLATE VII. \\ From the Middle Bagshot, Bournemouth. \\ Lygodium Kaulfussi (Heer).}

Figs. 1, 3, 4, 5, 7. Pinnæ of various sizes.

8. Pinna; the specimen should have been an inch longer, and only a part is engraved.

6. Portion magnified to show venation.

Hewardia regia, Ett. and Gard.

2. Fragment for comparison with Lygodium.

(The above in the Gardner Collection.) 


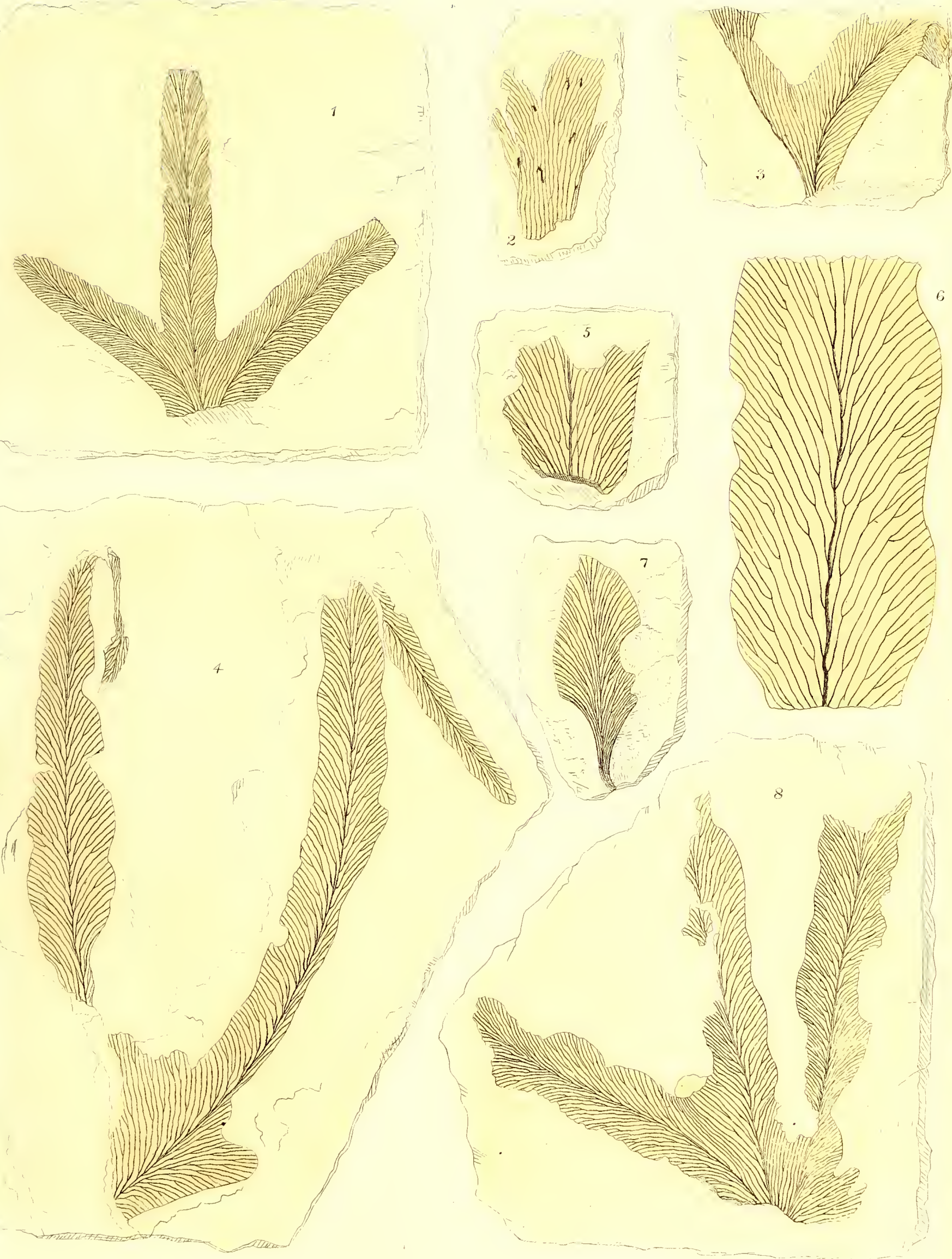






\section{PLATE VIII.}

\section{From the Middle Bagshot, Bournemouth. \\ Anemia subcretacea, Saporta.}

Fig. 1. Part of a large pinna.

2. A small pinna.

3, 4. Portions enlarged from different parts of frond for comparison of venation.

(The above in the Gardner Collection.) 

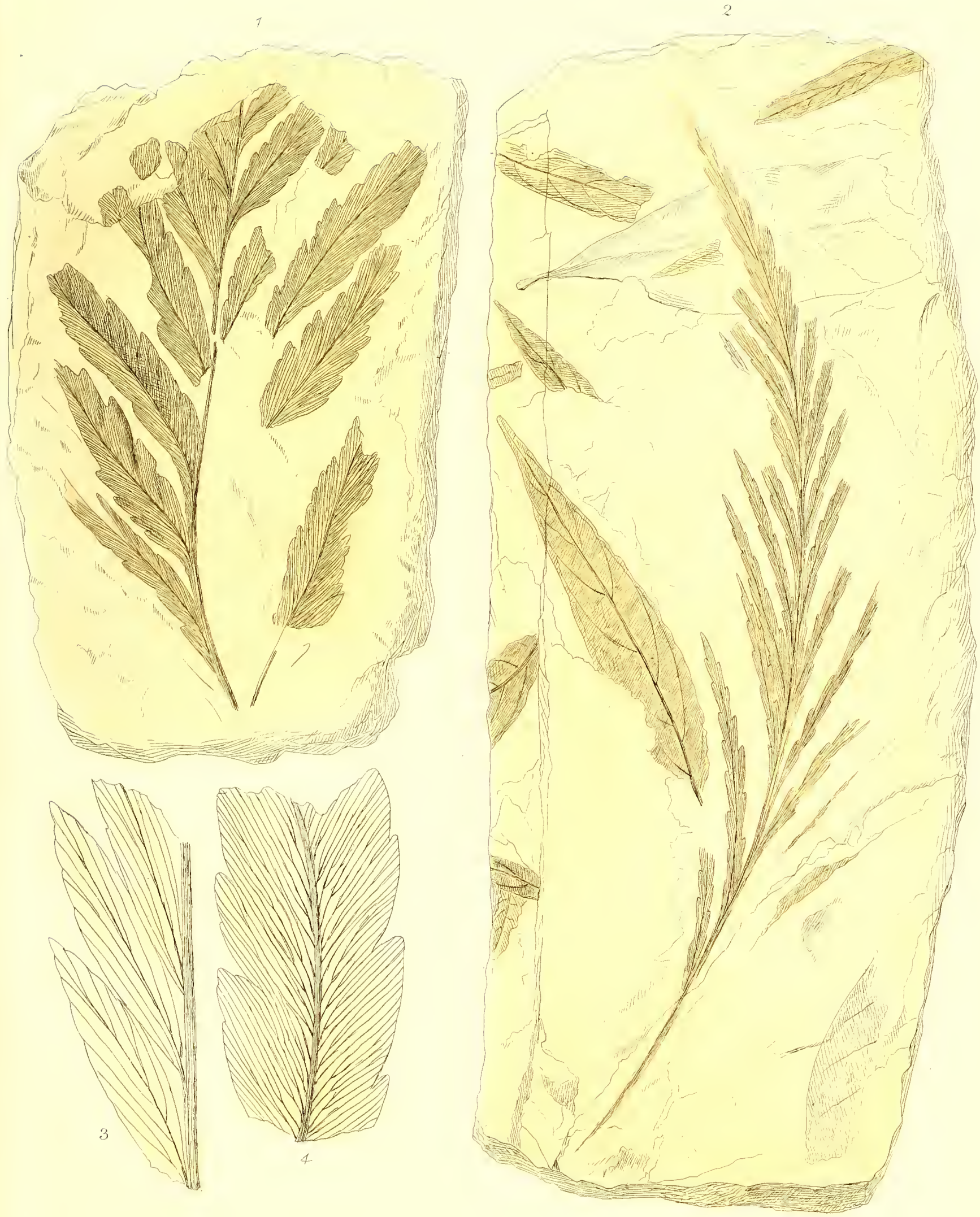




\section{PLATE IX.}

From the Middle Bagshot, Bournemouth.

Anemia subcretacea, Saporta.

Figs. 1, 3, 5. Fragments of pinna. (Gardner Collection.)

4. Parts of pinnules. (Mr. Pender's Collection.)

2. A large frond, reduced to one fourth the natural size. (Gardner Collection.) 



. 


\section{PLATE X.}

From the Middle Bagshot, Bournemouth.

Fig. 1. Adiantum apalophyllum, Saporta. (Gardner Collection.)

1 a. Part enlarged.

2. Gleichenia Hantonensis, Wanklyn, showing hooks and foliage attached, and sori.

$2 a$. Enlargement, showing two sori to each set of veins.

2b. A sorus magnified.

3. Pinnæ with sori.

4. Pair of llooks, with fragments of the midribs of pinnæ attached. (Figs. 2 to 4 in Woodwardian Museum.)

5. Woodwardia venosa, Ett. and Gard.

ó a. Enlargement. (Gardner Collection.)

6. Hewardia regia, Ett. and Gard.

6 a. Enlargement. (Gardner Collection.)

9. Goniopteris* Bunburii, Heer. A nearly entire pinna.

9 a. Enlargement of the venation,

10. Venation of another pinna enlarged. (Gardner Collection.)

11. Lygodium Kaulfussi, Heer. Fertile frond. (Mr. Baldry's Collection.)

From the Oldhaven Beds, Bromley.

7. Fragment of Fern, undetermined.

7 a. Enlargement. (Gardner Collection.)

Frou the Woolwich and Reading Beds, Counter Hill.

8. Pteris Prestwiclii, Ett. and Gard.

* Termed Phegopteris on p. 38. 

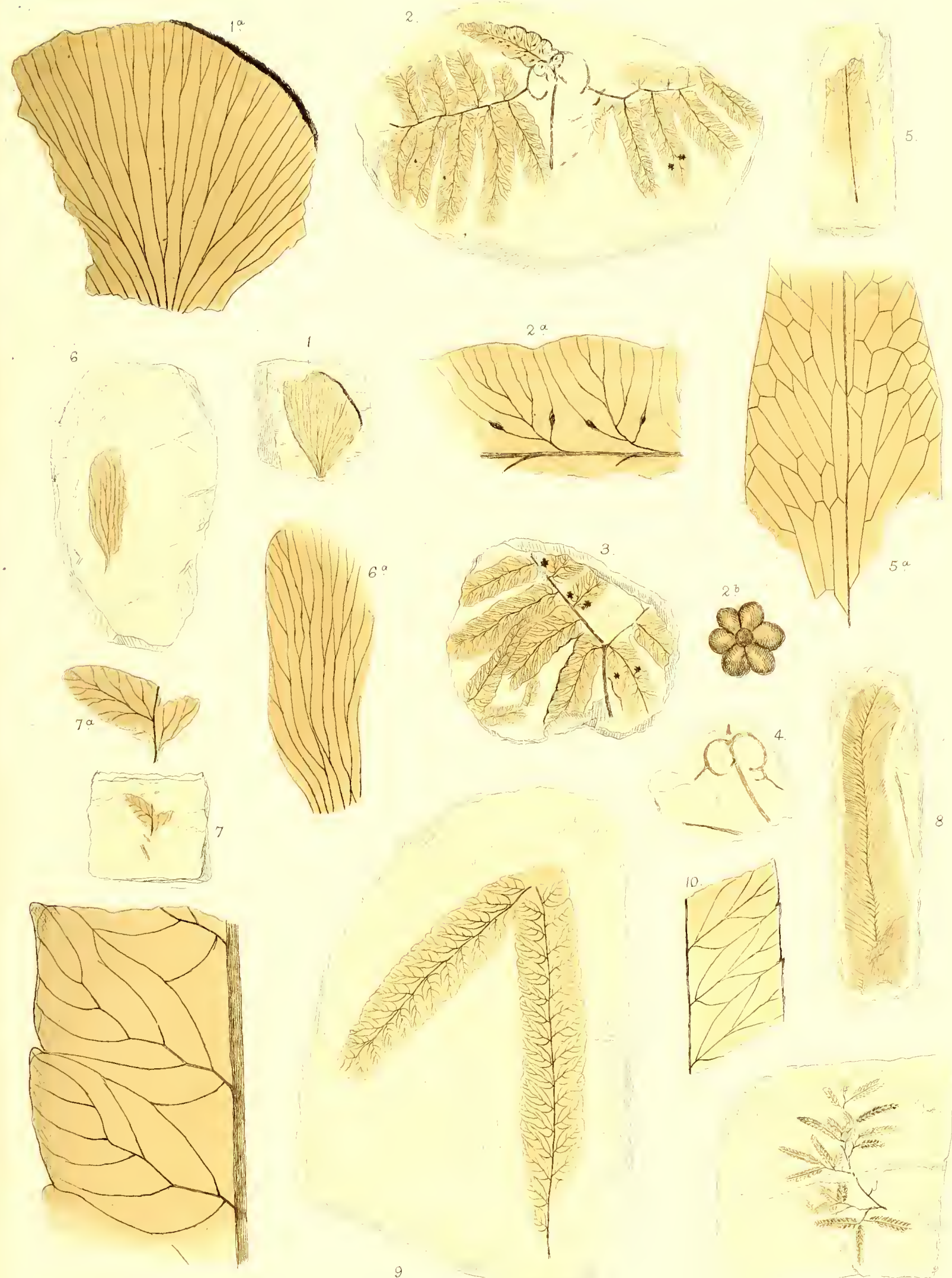

$9^{a}$ 




\section{PLATE XI.}

From the Middle Bagshot, Bournemouth.

Hewardia regia, Ett. and Gard.

Fig. 1. A magnificent specimen, showing marginal sori.

2, 3. Parts of smaller pinnæ.

4. Portion enlarged, showing anastomosing venation.

(Gardner Collection.) 


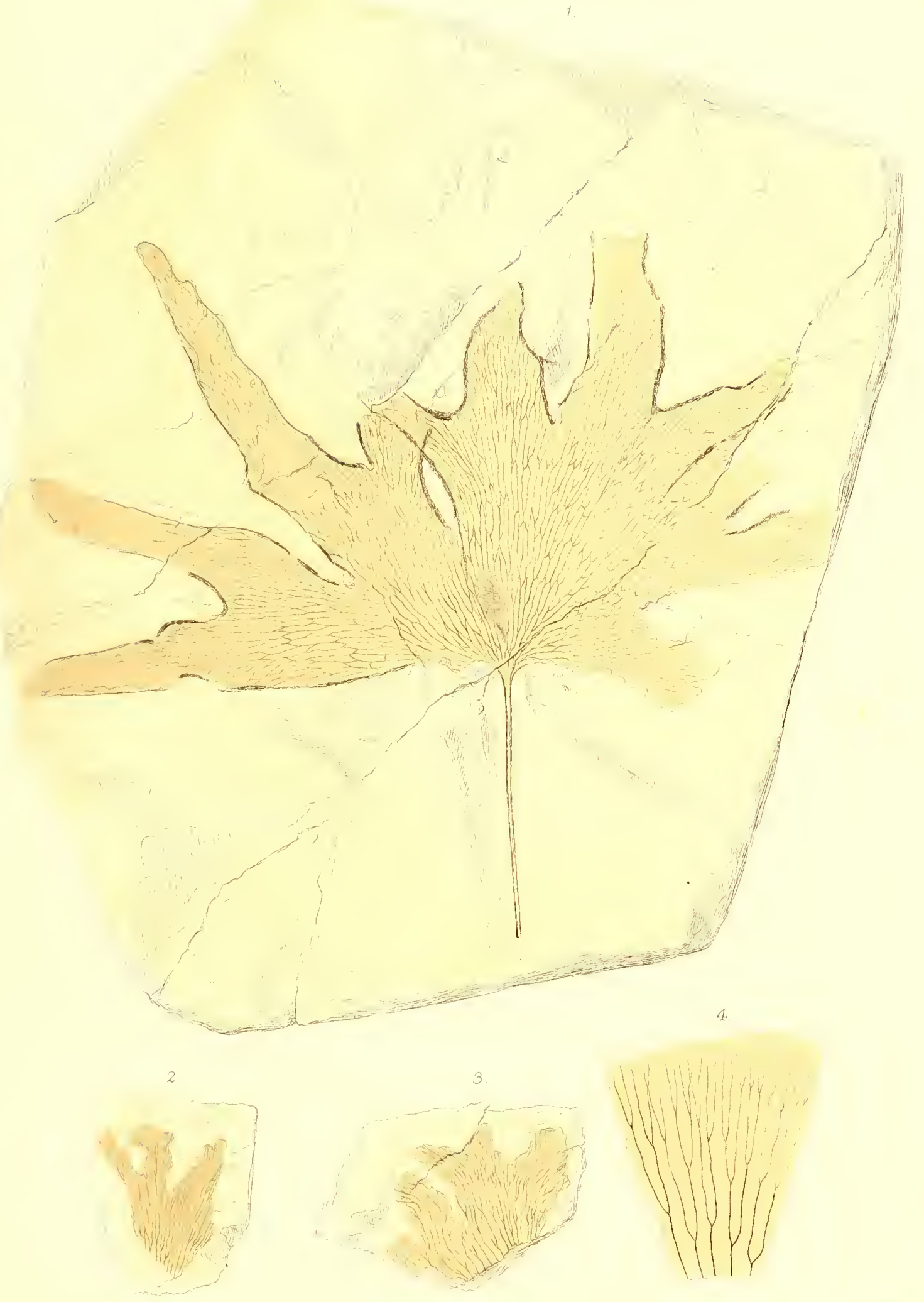




\section{PLATE XII.}

\section{From the Lower Bagehot, Alum Bay.}

Figs. 1-6. Marattia Hookeri, Ett. and Gard. (British Museum ${ }^{1}$ ).

$2 a$ and $4 a$. Apices of pinnæ enlarged.

$4 b$. Part of pimna enlarged.

6 a. Enlargement from a specimen showing secondary venation.

\section{From the Middle Bagshot, Bournemouth.}

7. Adiantum apalophyllum, Saporta (British Museum).

8. Glossochlamys transmutans, Ett. and Gard. (British Museum).

$8 a_{2} 8 b, 8 c$. Enlargements, showing position of sori.

9. Fern fragment, indeterminable (British Museum).

10. Podoloma polypodioides, Ett. and Gard. Enlargement of veins beneath sorus.

11. Pteris eocanica, Ett. and Gard. Fragment showing the relative proportion of terminal and lateral pinnæ (Jermyn Street Museum).

11 a. Enlargement.

I The specimens marked "Gardner Collection" in this work are now in the British Museum. 

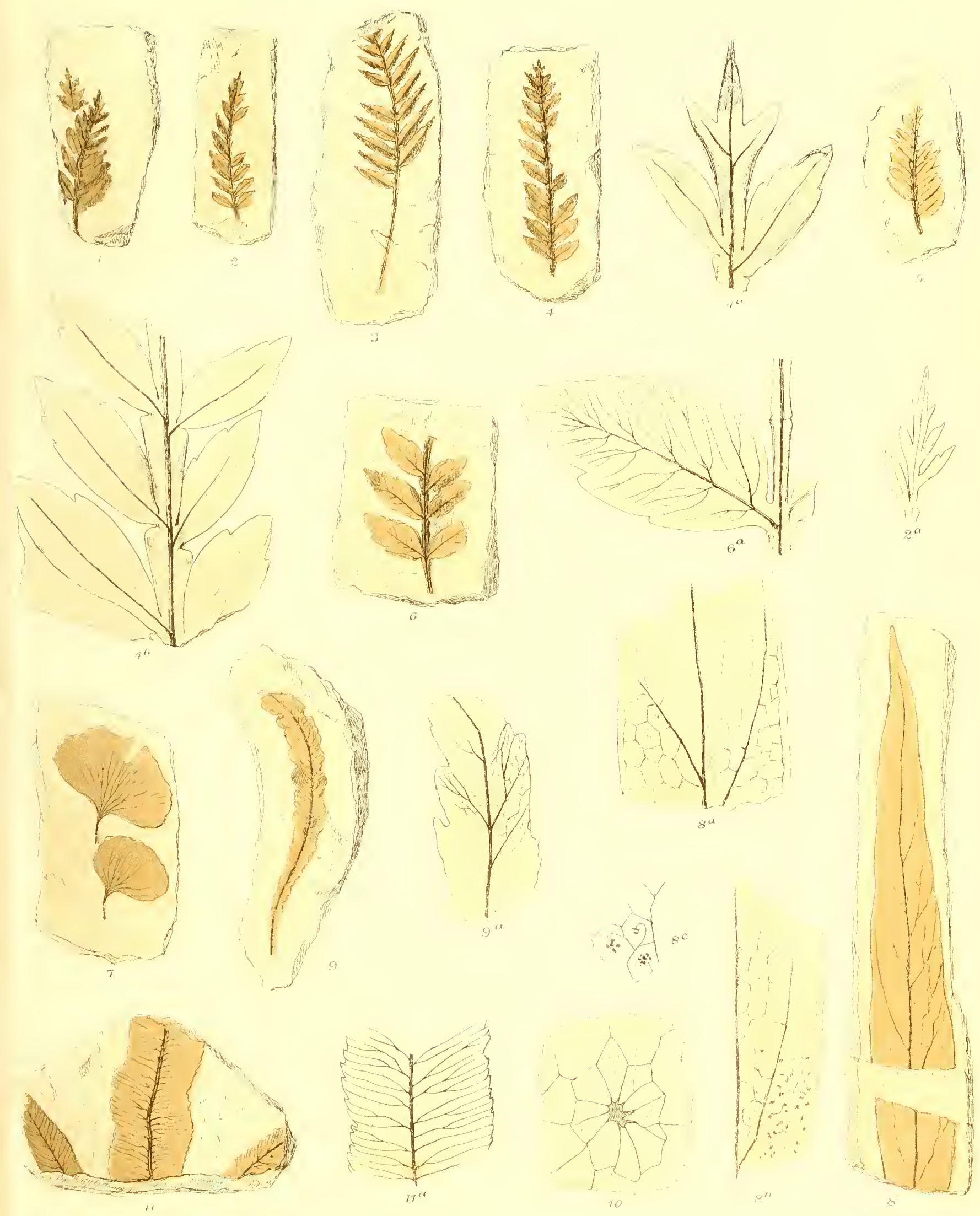



\section{PLATE XIII.}

From the Middle Bagshot, Bournemouth.

Figs. 1, 2, 3. Osmunda lignitum (Giebel, sp.). Terminations of pinnæ (British Museum).

4. Full size frond, showing base, part only figured.

$1 a, 3$ a , 4a. Enlargements.

8. Lygodium Kaulfussi, Heer. Dwarfed, barren frond (British Museum).

9. Simple frond, which when perfect tapered to a narrow base.

From the Ardtun Beds, Muli.

5. Onoclea hebraidica (Forbes, sp.). Part of frond near apex (Jermyn Street Museum).

5 a. Enlargement.

6. Fragment (Hunterian Museum, Glasgow University).

6 a. Enlargement.

From the Antrim Beds, Lovgh Nhagh.

7. Goniopteris Bunburii, Heer (Geological Survey Collection, Dublin).

รa. Enlargement. 


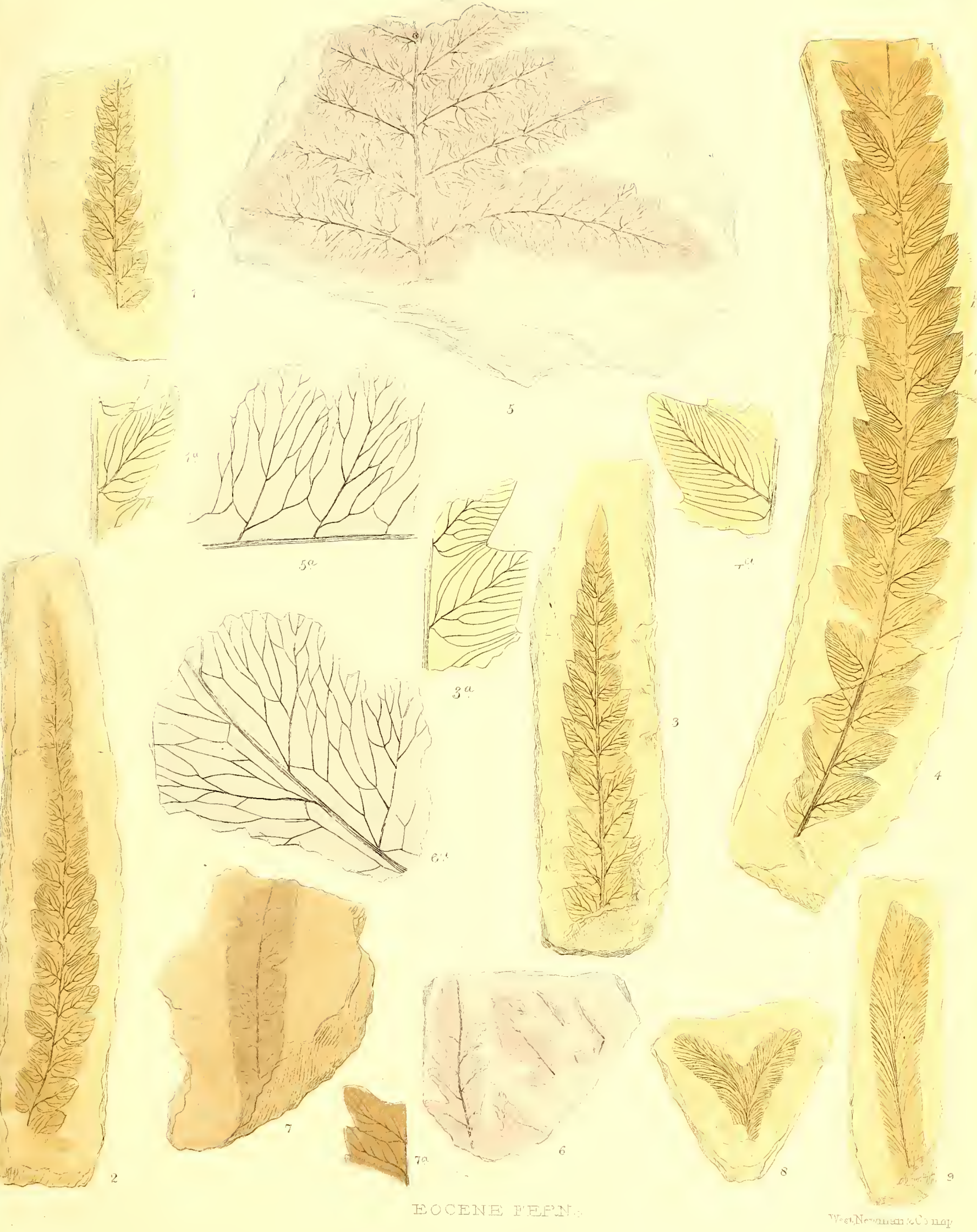




- 



